\title{
Essays on the economic effects of non-contributory social protection
}

Citation for published version (APA):

Mideros Mora, A. I. (2017). Essays on the economic effects of non-contributory social protection. [Doctoral Thesis, Maastricht University]. Boekenplan. https://doi.org/10.26481/dis.20171206aimm

Document status and date:

Published: 01/01/2017

DOI:

10.26481/dis.20171206aimm

Document Version:

Publisher's PDF, also known as Version of record

\section{Please check the document version of this publication:}

- A submitted manuscript is the version of the article upon submission and before peer-review. There can be important differences between the submitted version and the official published version of record.

People interested in the research are advised to contact the author for the final version of the publication, or visit the DOI to the publisher's website.

- The final author version and the galley proof are versions of the publication after peer review.

- The final published version features the final layout of the paper including the volume, issue and page numbers.

Link to publication

\footnotetext{
General rights rights.

- You may freely distribute the URL identifying the publication in the public portal. please follow below link for the End User Agreement:

www.umlib.nl/taverne-license

Take down policy

If you believe that this document breaches copyright please contact us at:

repository@maastrichtuniversity.nl

providing details and we will investigate your claim.
}

Copyright and moral rights for the publications made accessible in the public portal are retained by the authors and/or other copyright owners and it is a condition of accessing publications that users recognise and abide by the legal requirements associated with these

- Users may download and print one copy of any publication from the public portal for the purpose of private study or research.

- You may not further distribute the material or use it for any profit-making activity or commercial gain

If the publication is distributed under the terms of Article $25 \mathrm{fa}$ of the Dutch Copyright Act, indicated by the "Taverne" license above, 


\section{Essays on the}

Economic Effects of

Non-contributory

\section{Social Protection}

Andrés Iván Mideros Mora 

Essays on the Economic Effects of Non-contributory Social Protection 
C 2017 Andrés Iván Mideros Mora

ISBN 9789086664412

Cover illustration: Pawel Kuczynski

Publisher: Boekenplan, Maastricht www.boekenplan.nl

All rights reserved. No part of this publication may be reproduced, stored in a retrieval system, or transmitted in any form, or by any means, electronic, mechanical, photocopying, recording or otherwise, without the prior permission in writing, from the author. 


\title{
Essays on the economic effects of non- contributory social protection
}

\author{
DISSERTATION
}

to obtain the degree of doctor at Maastricht University,

on the authority of the Rector Magnificus, Prof. Dr. Rianne M. Letschert in accordance with the decision of the Board of Deans, to be defended in public on Wednesday 6 December 2017, at 12:00 hours

by

Andrés Iván Mideros Mora 
Promoter:

Prof. Dr. Cathal O’Donoghue

Supervisor:

Prof. Dr. Franziska Gassmann

Assessment committee:

Prof. Dr. Adam Szirmai (Chair)

Prof. Dr. Armando Barrientos (University of Manchester)

Dr. Gijs Dekkers (Federal Planning Bureau, Belgium)

Dr. Nyasha Tirivayi 


\section{Acknowledgments}

"If you want to go fast, go alone. If you want to go far, go together".

African proverb.

This dissertation would not have been possible without the support of many. I extent my gratitude to my family, friends and all who have been in my life. This book is dedicated to them. It is my great pleasure to be able to thank Franziska and Cathal for providing continued support. I am also grateful to Eddy, Nyasha, Armando and Gijs for having accepted to serve as committee members.

I have been always looking for solutions to eradicate poverty and inequality, because of that I came to Maastricht. During the master in public policy I was inspired from Michael Cichon who introduced me to social protection. At an early stage of the $\mathrm{PhD}$, it was Eddy Szirmai who inspired me on socio-economic development. I use his book when I teach development in Ecuador. Later, I had the opportunity to work with Franziska and Pierre in Cambodia. I learned more than ever. I thank Franziska to guide me throughout this long process. Thanks for the trust and patience. I have also had the opportunity to serve in Ecuador as vice minister for the eradication of poverty, and as minister of development and planning, I thank Pabel Muñoz and President Lenin Moreno for that. This dissertation benefits from that experience. 
Finally, I would like to thank MGSoG and UNU-MERIT staff members, I have benefited from their comments and experience. Thanks in particular to Eveline, Mindel and Susan for their guidance and permanent help. And for a variety of reasons, I would like to thank Alejandro, Andi, Andrea, Carlos, Charlotte, Craig, Eleni, George, Giorgio, Irina, Jennifer, Julieta, Katrin, Lorena, Ortrun, Patricia, Paula, Santana, Sebastián, Simone, Tash, and Yesuf. I would also like to thank Thomas A. Gavin, Professor Emeritus, Cornell University, for help with editing the English in the dissertion; and the author of the cover illustration, Pawel Kuczynski, for authorizing it. 


\section{Contents}

Chapter 1 - Introduction............................................................................. 1

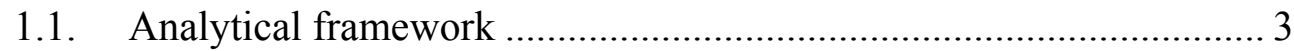

1.2. Research questions ...................................................................... 6

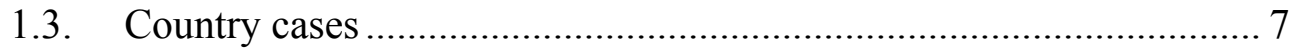

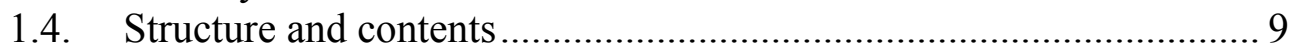

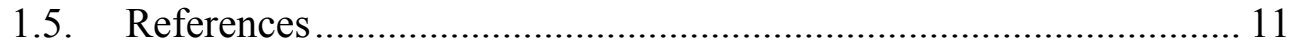

Chapter 2 - Labour supply: A unitary discrete choice model................. 16

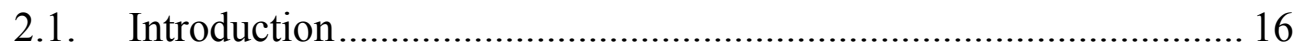

2.2. Theoretical framework ................................................................... 19

2.2.1. The unitary discrete choice model.................................. 22

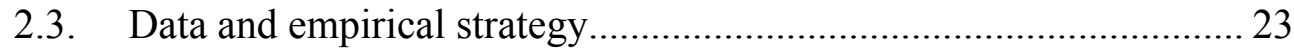

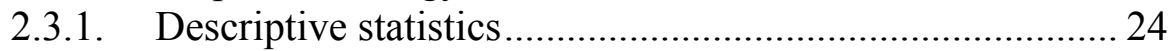

2.3.2. Empirical specification .............................................. 30

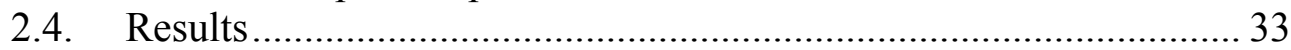

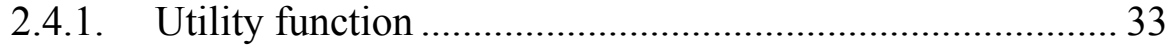

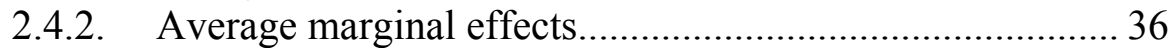

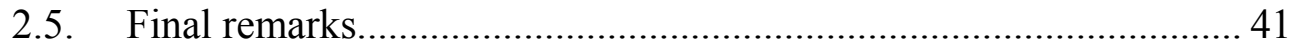

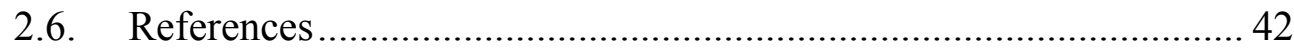

Annex 2.1. Paid-labour income (Heckman selection equation)................... 48

Chapter 3 - Accumulation of human capital: A cost-effectiveness

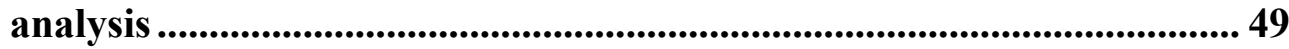

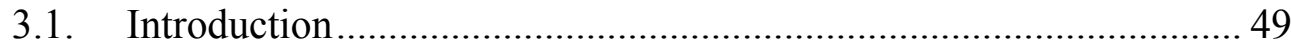

3.2. The theory of accumulation of human capital ............................... 52

3.2.1. Social transfers and investments in human capital............. 56

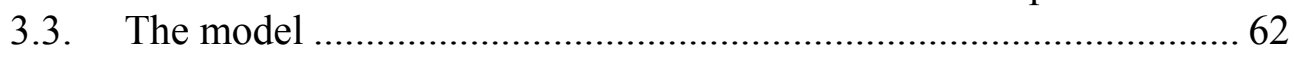

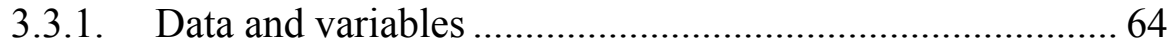

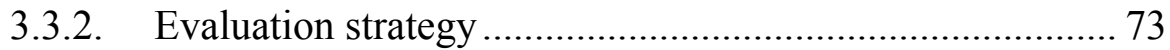

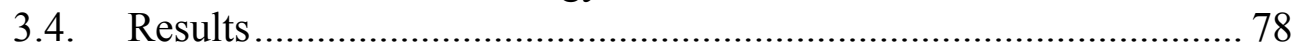

3.5. Final remarks..................................................................... 82

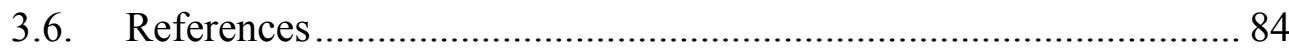




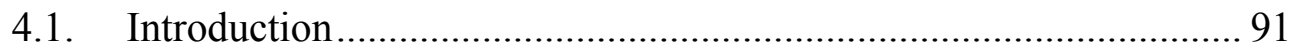

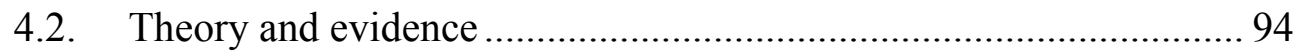

4.2.1. Social mobility and poverty dynamics: the role of social transfers 95

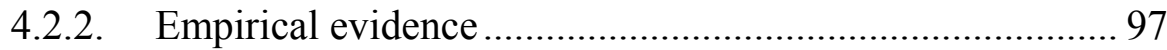

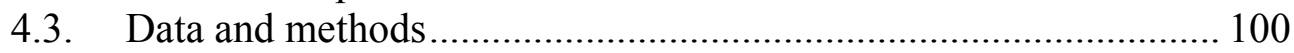

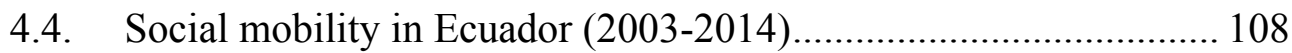

4.4.1. Determinants of social mobility .................................... 109

4.4.2. The effect of social transfers on social mobility ............. 115

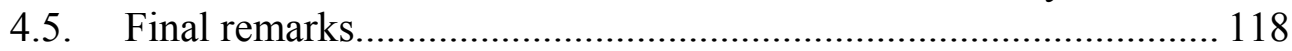

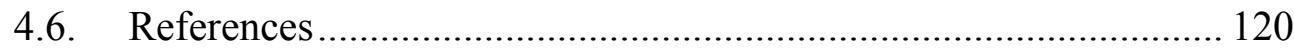

Annex 4.1. Variables included in RS index and 2008 ........................... 126

Chapter 5 - The rate of return of non-contributory social protection 127

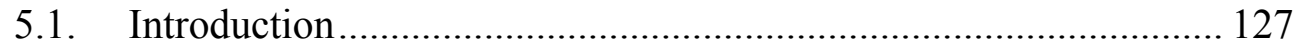

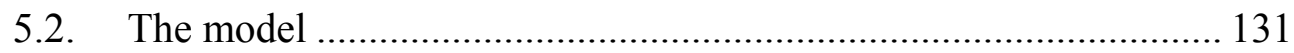

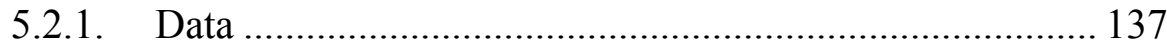

5.2.2. Behavioural effects: school attendance .......................... 141

5.2.3. Economic returns for schooling .................................... 144

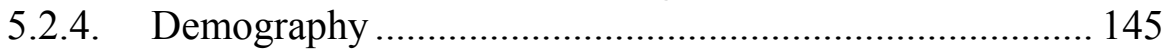

5.3. Rate of return on non-contributory social protection..................... 146

5.3.1. Household consumption ................................................. 146

5.3.2. Accumulation of human capital ..................................... 147

5.3.3. Poverty and inequality ................................................. 148

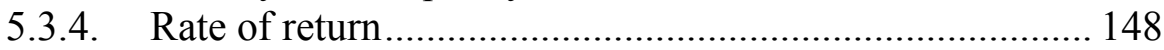

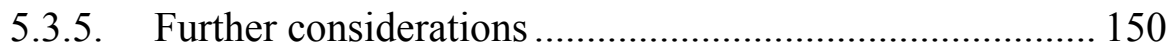

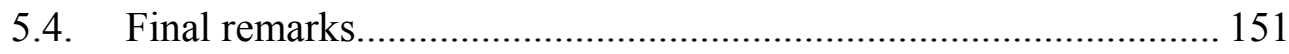

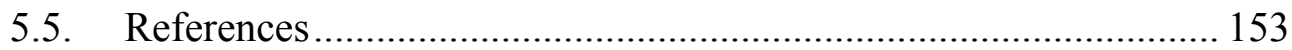

Chapter 6 - Concluding remarks .......................................................... 159

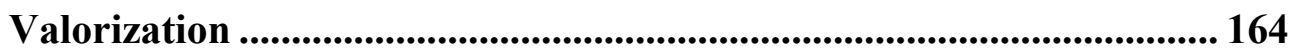

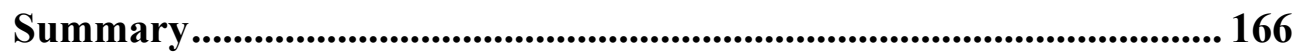

Biography.......................................................................................................... 170 


\section{List of tables}

Table 2.1. Descriptive statistics (ENEMDUR - December 2012) ............. 28 Table 2.2. \% of persons by paid-labour condition (ENEMDUR - December

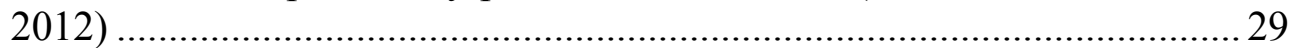

Table 2.3. Dependency ratio (ENEMDUR - December 2012) .................. 30

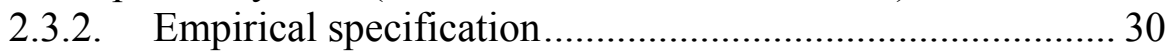

Table 2.4. Distribution of households across labour choices...................... 32

Table 2.5. Reduced utility function coefficients - Equation 2 (labour choice)

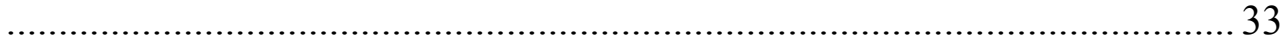

Table 2.6. Utility function coefficients - Equation 2 (labour choice) ......... 35

Table 2.7. Average marginal effects of the BDH on paid-labour ................ 39

Table 2.8. Average marginal effects on paid-labour (partners) ................... 40

Table 3.1. BDH recipients, school attendance, and schooling by age (urban pooled average 2009-2013)......................................................................... 67

Table 3.2. BDH recipients, school attendance, and schooling by age (rural

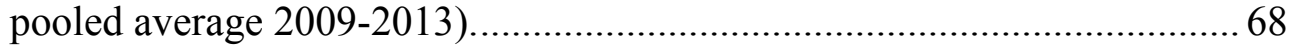

Table 3.3. School delay and marriage by age (pooled average 2009-2013).69 Table 3.4. School attendance by age and income level (urban pooled average

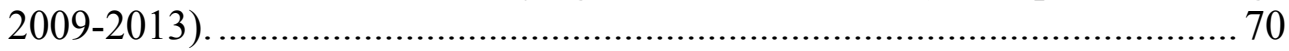

Table 3.5. School attendance by age and income level (rural pooled average

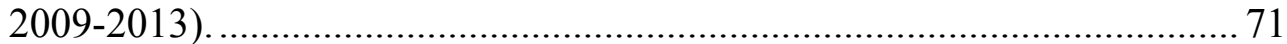

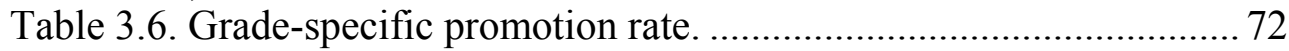

Table 3.7. Age-specific survival rate. ..................................................... 72

Table 3.8. Two-stage probit model and average marginal effects on school attendance and marriage status (ENEMDU 2009-2013).......................... 77

Table 3.9. Dynamic cohort microsimulation (married, school attendance and

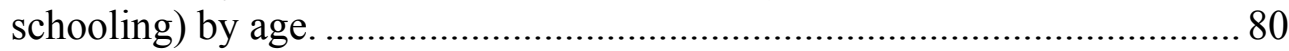

Table 3.10. Cost-effectiveness analysis of policy scenarios by age. .......... 81

Table 3.11. Schooling inequality by income bracket................................. 82

Table 4.1. Descriptive statistics ......................................................... 103

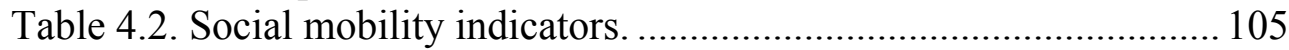

Table 4.3. Poverty transition matrix........................................................ 109

Table 4.4. Determinants of absolute social mobility in Ecuador (2003-20092014)

Table 4.5. Determinants of relative social mobility in Ecuador (2003-20092014).

Table 4.6. The effect of the BDH on absolute social mobility in Ecuador (2003-2009-2014). 
Table 4.7. The effect of the BDH on absolute social mobility in Ecuador (2009-2014) - extended panel

Table 5.1. Social protection instruments and policy options.

Table 5.2. Average marginal effects on the probability of attending school.

Table 5.3. 2SLS estimation of logarithm of household consumption per capita, by region, and poverty condition.

Table 5.4. Population projection by period, region, gender, and age (thousands).

Table 5.5. Benefits, cost, and rate of return (RoR) of social protection in Cambodia. 150

\section{List of figures}

Figure 1.1: Social protection and economic performance ........................................

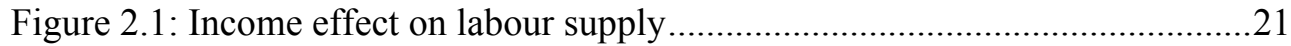

Figure 3.1: Relation between eligibility and RS index (2009) ..............................74

Figure 5.1: Social protection and socio-economic development.............................136 


\section{Chapter 1 - Introduction ${ }^{1}$}

Global GNI per-capita (PPP, current international \$) was 16,100 USD in 2016. However, $10.7 \%$ of the population was still living in poverty on less than 1.90 USD a day (World Bank, 2017). The first of the sustainable development goals (SDG) that was approved in 2015 by the United Nations' General Assembly aimed to "end poverty in all its forms everywhere", and it mandated to "implement nationally appropriate social protection systems and measures for all" (United Nations, 2015, p. 15). Along this line, the International Labour Organization (ILO)'s recommendation 202 urged countries to "establish as quickly as possible and maintain their social protection floors comprising basic social security guarantees" (International Labour Organization, 2012). Moreover, the ILO, the World Bank, and UNICEF share global initiatives for universal social protection (UNICEF and World Bank (2013) and ILO and World Bank (2015)).

The ILO and the World Bank understand social protection as the integrated set of policies designed to ensure income security and support to all people across the life cycle - paying particular attention to the poor and the vulnerable. Anyone who needs social protection should be able to access it.

Universal social protection includes adequate cash transfers for all who need it, especially: children; benefit/support for people of working age in case of maternity, disability, work injury or for those without jobs; and pensions for all older persons. This assistance services, public works programs and other schemes guaranteeing basic income security (International Labour Organization \& World Bank, 2015, p. 1).

Social protection instruments can be contributory (i.e., insurance based) and non-contributory (i.e., social transfers that are financed by the public

\footnotetext{
${ }^{1}$ This chapter is based on previous work published in a research report (Mideros, Gassmann, \& Mohnen, 2012), a working paper (Cherrier, Gassmann, Mideros, \& Mohnen, 2013), and a conference paper (Mideros A. , 2014).
} 
budget). Non-contributory mechanisms are effective at increasing social protection and in guaranteeing some level of protection for all (Cichon, Behrendt, \& Wodsak, 2011). Social protection measures aim to reduce poverty and inequality, improve capacity for smoothing consumption, help households to manage risk, and redistribute income (Gassmann, 2011). Specifically, cash transfers have been implemented largely in developing countries, and they have been integrated into anti-poverty programmes (Barrientos \& Santibañez, 2009).

Social protection is a human right and, therefore, it is an obligation of states to guarantee it to their citizens. ${ }^{2}$ Non-contributory social protection has been proven to be affordable in low- and middle-income countries, at least for a minimum level of benefits (Hagemejer, 2009). In addition, international research has concluded that its effects on health and education were positive (see for example Handa and Davis (2006), Barrientos and Scott (2008), Barrientos and Niño-Zarazúa (2010), Arnold et al (2011), IEG (2011), Barrientos (2012), Alderman and Yemtsov (2012), UNICEF (2012), Mideros et al. (2012), Tirivayi et al. (2013), World Bank (2015), and Bastagli et al. (2016)). However, there are still questions regarding its economic effects over the medium and long term. This is relevant, because if economic effects are positive, this strengthens the case for implementation in countries with scarce resources. The objective of this thesis is to shed new light on the economic effects of non-contributory social protection and to understand under what conditions social transfers promote a sustainable path out of poverty, while fostering economic performance.

\footnotetext{
${ }^{2}$ Article 22 of the Universal Declaration of Human Rights, and Article 9 of the International Covenant on Economic, Social and Cultural Rights. 


\subsection{Analytical framework}

Following Barrientos, the scope of my study focused on the micro-level, because "the dimension of growth relevant to social transfers is growth among the households in poverty" (Barrientos, 2012, p. 12) and, then, "we must focus on the poor and the particular circumstances that they face, recognising that those in poverty generally face a qualitatively different set of opportunities to those better off" (Barrientos \& Scott, 2008, p. 2).

There are recent analytical frameworks that link social transfers with economic performance. Barrientos (2012) proposed a basic framework for tracing the effects of social transfers on economic growth. Based on empirical evidence, the author identified three growth-mediating processes: i) alleviating credit constraints, if regular and reliable social transfers can promote savings and investments, ii) improving consumption and asset security, if social transfers help poor households to smooth consumption and secure assets from external shocks, and, iii) improving household resource allocation. Moreover, Barrientos (2012) stated that social transfers positively affect the following outcomes of productive capacity: asset protection and accumulation, labour supply, and local economy.

A different framework was proposed by Alderman \& Yemtsov (2012), who identified three main pathways through which social transfers promoted economic growth at the micro-, meso-, and macro-level: i) accumulating and protecting human capital and productive assets, and fostering investments and high return strategies for the poor, ii) generating local economic effects by enhancing community assets and infrastructure, but also causing spillover effects on non-beneficiary households and small businesses, and iii) stabilizing aggregate demand and improving social cohesion. 
Following this line of analysis, Mideros et al. (2012) used the analytical perspective of socio-economic development that was proposed by Szirmai (2012) to elaborate the links among non-contributory social protection, economic performance, and socio-economic outcomes (Fig. 1.1). Proximate sources of economic growth are those that are related directly to economic output as disembodied technological change, capital accumulation, and labour quality. Social transfers have proven to generate positive effects on accumulation of human and physical capital. Intermediate sources of development include trends in national and international demand, changes in economic, social, and technological policies, and changes in the terms of trade. Social transfers can stabilize aggregate demand at the time that it is a social and economic policy by itself. Finally, ultimate sources of development were related to geographic conditions, demographic trends, social attitudes and capabilities, political and social institutions, and class and power relations, among others. Social transfers have the potential to increase social cohesion and economic inclusion by reducing inequalities and fostering social mobility (Mideros, Gassmann, \& Mohnen, 2012).

Non-contributory social transfers increase disposable income and consumption of households directly. However, social transfers also affect household behaviour through income and non-income effects. Income security encourages households to invest in health, education, livelihoods, and productive activities. Moreover, transfer design and conditionality may further encourage certain decisions. Human capital is accumulated by investments in health and education, and this subsequently increases labour productivity, depending on the coverage and quality of public services. In addition, productive investments increase physical capital. In addition, social transfers affect labour supply positively. Although social transfers may 
reduce labour due to a higher level of income for any level of labour, this effect is unlikely to happen among poor individuals unless the transfer amount is high enough to cover all their basic needs and make leisure really enjoyable. Additionally, social transfers may help poor households solve credit constraints and to afford transportation and transaction costs. Finally, social protection may enhance social cohesion by reducing inequalities and by promoting socio-economic inclusion (Mideros, Gassmann, \& Mohnen, 2012).

Fig. 1.1: Social protection and economic performance

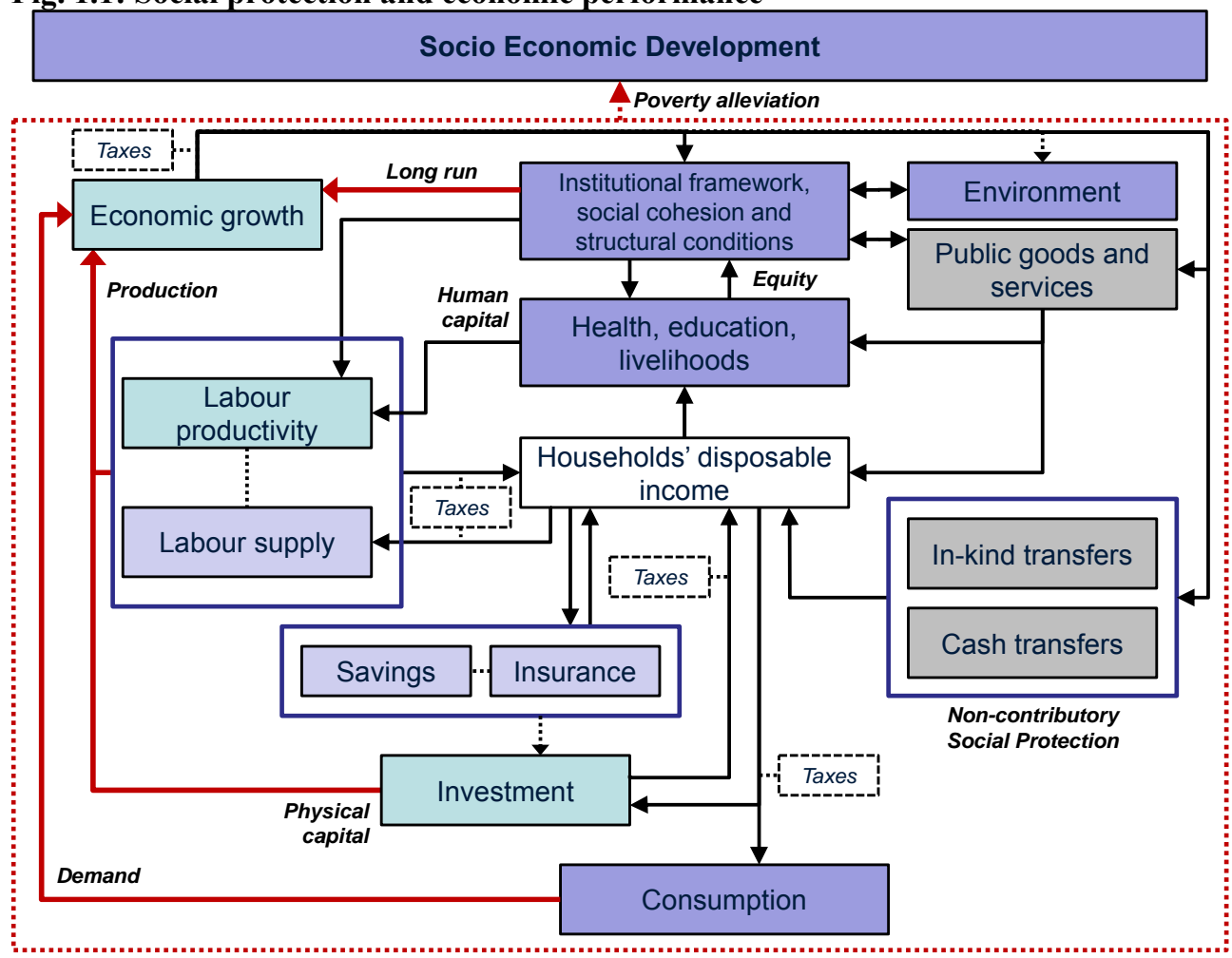

Source: Cherrier et al. (2013) based on Mideros et al. (2012).

On the other hand, non-contributory social transfers are financed by general public revenues, and then their cost includes the effects of taxation or budget 
reallocation. However, because social transfers enhance aggregate demand, generate local multipliers, increase productive capacity, and promote institutional changes, they foster economic capacity and growth. Nevertheless, economic effects may not happen overnight and, therefore, the analysis needs to take time into account.

\subsection{Research questions}

The research question of this thesis is Under what conditions do noncontributory investments in social protection foster economic performance? To answer it, four sub-questions are explored: i) Under what conditions do non-contributory social transfers promote participation in the labour market? ii) How and to what extent do non-contributory social transfers affect accumulation of human capital? iii) Under what conditions do noncontributory social transfers foster social mobility? iv) what is the economic rate of return of investments in non-contributory social protection?

This thesis presents a series of essays on the economic effects of social transfers. Each chapter is an independent paper that focuses on one of these sub-questions, but there is some overlap in the introductions and literature reviews of the chapters. Different econometric models and evaluation strategies were used to estimate the effect of social transfers, and microsimulation models were used for analysis of ex-ante evaluation and cost-effectiveness. ${ }^{3}$

\footnotetext{
${ }^{3}$ For a methodological survey of microsimulation, see Li and O'Donoghue (2013). For its use in policy analysis, see Bourguignon and Spadaro (2006) and Spadaro (2007). 6
} 


\subsection{Country cases}

Two country cases were studied. First, Ecuador is a middle-income country that had a GNI per-capita (PPP, current international \$) of 11,070 USD in 2016 (World Bank, 2017); Ecuador had a Human Development Index of 0.739 in 2015, and it ranked 89 out of 188 countries (UNDP, 2017). Total population was 14.5 million in 2010 (Ministerio Coordinador de Desarrollo Social, 2017). In December 2016, the active population was 7.9 million people, unemployment was $5.2 \%$, and underemployment was $19.9 \%$; the poverty head count by income was $22.9 \%$ and the Gini coefficient for income was 0.47 (Ministerio Coordinador de Desarrollo Social, 2017). From a multidimensional perspective of poverty, the main deprivations in Ecuador were basic services (safe water and sewerage), social protection, and inequalities (Mideros A. , 2012).

Administrative data on education records and recipients of social transfers from the National Employment, Unemployment and Underemployment Survey (ENEMDUR) of the National Institute of Statistics and Censuses (INEC) were used also. The ENEMDUR is a cross sectional survey that is conducted quarterly for urban households and twice a year (June and December) for rural households, excluding the Galapagos Islands. The sample framework is representative at the province level in the case of the Coast and the Sierra regions, and it is representative at the regional level in the case of the Amazon. The ENEMDUR's first objective is to collect labour and income data, but it also provides relevant information about individuals and households, including social transfers.

The analysis for Ecuador evaluated the cash transfer programme called Bono de Desarrollo Humano (BDH). The $\mathrm{BDH}$ is a cash transfer with soft conditionality (i.e., monitoring is weak) that children must attend school and 
health controls. It provides a flat transfer without consideration of household size, and it is not conditional on whether the household is employed. In 2003, each beneficiary household received 15 USD per month, irrespective of household size. The amount was increased in 2007, 2009, and 2013 to 30 USD, 35 USD, and 50 USD, respectively. Targeting was designed and based on a multivariate welfare indicator, which was estimated by principal component analysis, with a value between 0 and 100 . The threshold to receive the BDH was defined for the lowest $40 \%$ of the indicator in 2003, at 50.6 points in 2009, and at 36.5 points in 2014. The thresholds for 2009 and 2014 were the equivalent of the consumption poverty line. An additional eligibility condition required the presence of school age children under 18 years old in the household.

The second country case is Cambodia. It is a low income country that had a GNI per-capita (PPP, current international \$) of 3,510 USD in 2016 (World Bank, 2017); Cambodia had a Human Development Index of 0.563 in 2015, and it ranked 143 out of 188 countries (UNDP, 2017). According to the General Population Census of 2008, the total population was 13.4 million. Eighty per cent of the population lived in rural areas, 51\% were women, $33.7 \%$ were children (0-14), and $4.3 \%$ were elderly $(65+)$ (National Institute of Statistics, 2009).

The labour force $(15+)$ contained approximately 7 million people in 2008. Among working persons, $34.5 \%$ had not completed primary education. In $2008,72.5 \%$ of employment was generated in agriculture, forestry, and fisheries, services and sales (19.3\%), and industry (8.6\%). Of those who worked, $82.5 \%$ were unpaid or self-employed (i.e., vulnerable employment). Poverty, which was measured by average household consumption per capita, declined from $62.0 \%$ to $30.1 \%$ between 2004 and 2009 , below the poverty 
line of 0.93 USD and 1.38 USD per-capita daily income, respectively. However, the Gini coefficient of per capita consumption increased from 0.38 in 1993 , to 0.40 in 2004 , and to 0.43 in 2007 . In 2009 , the average monthly income per capita was 94 USD (National Institute of Statistics, 2010).

The analysis for Cambodia was based on the National Social Protection Strategy for the Poor and Vulnerable (NSPS), which was launched by the Government of Cambodia in 2011 to contribute to the rehabilitation and stability of the economy, and to enhance human capital. Data are from the Cambodia Socio-Economic Survey (CSES) 2004 and 2009 that were collected by the National Institute of Statistics (NIS) of the Ministry of Planning (MoP), and additional data came from available design proposals and costing studies (e.g., Hennicot (2012)). The NSPS sees social protection as a mechanism to protect people against different kinds of risk, and to bring the poor out of poverty. The NSPS recognizes four vulnerable groups: i) infants and children, ii) girls and women of reproductive age, iii) households that are vulnerable to food insecurity and unemployment, and, iv) special vulnerable groups (Royal Government of Cambodia, 2011). One of the main elements of the NPSP is the Social Safety Net (SSN) programme, which includes public work programmes (PWP), social transfers, and targeted subsidies. In this thesis, I calculated an ex-ante evaluation of the rate of return of social transfers.

\subsection{Structure and contents}

The thesis is organized as follows. In Chapter 2, I examined the effect of unconditional cash transfers on labour supply in Ecuador. I argued that there were no disincentives (negative income effect) of social transfers on labour supply in the case of poor adults, because leisure could not be assumed to be 
a normal good under such conditions. A unitary discrete labour supply model was estimated for the case of Ecuador. Results showed that cash transfers, unconditional in labour, did not produce labour disincentives in the case of household heads, but they may have paid for housework and childcare that was provided by partners and single adults. However, gender inequality in labour markets and for domestic care must be addressed by complementary policies.

In Chapter 3, I analysed the effect of social transfers on accumulation of human capital in Ecuador as a key example of the long-term economic effects of investments in social transfers. A dynamic, cohort microsimulation model was used to analyse cost-effectiveness of different policy scenarios in Ecuador. Results showed that cash transfers promoted accumulation of human capital to a rather limited extent. Transfers targeted at critical ages were the most cost-effective in promoting accumulation of human capital.

In Chapter 4, I studied an additional perspective of long-term effects of social transfers in Ecuador. Using administrative panel data, I analysed the determinants of social mobility in Ecuador using a multivariate welfare index, and I evaluated the effect of social transfers. Results showed that social policies should focus on vulnerabilities that are related to household composition, the accumulation of human capital, and the accumulation of durable goods. However, complementary policies that address gender, ethnic, geographical equity, and reproductive health are necessary to promote social mobility. Finally, I showed that social transfers fostered social mobility, especially for larger per capita transfers and, especially, if the transfer was complemented with economic inclusion programmes.

In Chapter 5, I estimated the rates of return of non-contributory social transfer programs in Cambodia using household level data. I went beyond 
standard cost efficiency analyses by developing a dynamic micro simulation model. The model showed that social protection promoted equitable economic growth by enhancing human capital and fostering economic performance at the micro level. A positive rate of return was identified that showed that social protection must be seen as an economic investment rather than only as a cost.

Finally, I presented concluding remarks in Chapter 6. The thesis makes a contribution in three different ways. First, new micro-level empirical evidence was presented for the cases of Ecuador and Cambodia, contributing to the understanding of poverty and poverty reduction in these countries. Second, new theoretical insights were generated regarding labour supply, accumulation of human capital, social mobility, and poverty traps. Third, microsimulation models were shown to be a powerful tool for ex-ante evaluation and analysis of cost-effectiveness of social transfers.

Moreover, the societal relevance of the study rests on existing policy recommendations to end poverty, to promote inclusive economic growth, and to reduce inequality, which are part of the sustainable development goals (SDG). The thesis contributes to the understanding of poverty traps and social mobility, and how social transfers should be designed and complemented in order to achieve economic effects and a sustainable way out of poverty.

\subsection{References}

Alderman, H., \& Yemtsov, R. (2012). Productive role of safety nets. Washington D.C.: The World Bank.

Arnold, C., Conway, T., \& Greenslade, M. (2011). Cash transfers. Department for International Development, DFID. 
Barrientos, A. (2012). Social transfers and growth: What do we know? What do we need to find out? World Development, 11-20.

Barrientos, A., \& Niño-Zarazúa, M. (2010). Effects of non-contributory social transfers in developing countries: A compendium. Geneva: International Labour Organization.

Barrientos, A., \& Santibañez, C. (2009). New forms of social assistance and the evolution of social protection in Latin America. Journal of Latin American Studies, 41, 1-26.

Barrientos, A., \& Scott, J. (2008). Social transfers and growth: A review. Manchester: BWPI Working Paper 52.

Bastagli, F., Hagen-Zanker, J., Harman, L., Barca, V., Sturge, G., Schmidt, T., \& Pellerano, L. (2016). Cash transfers: what does the evidence say? London: Overseas Development Institute.

Bourguignon, F., \& Spadaro, A. (2006). Microsimulation as a tool for evaluating redistribution policies. Journal of Economic Inequality, 4, 77-106.

Cherrier, C., Gassmann, F., Mideros, A., \& Mohnen, P. (2013). Making the investment case for social protection. Methodological challenges with lessons learnt from a recent study in Cambodia. Florence: Unicef Office of Research Working Paper 2013-06.

Cichon, M., Behrendt, C., \& Wodsak, V. (2011). The UN Social Protection Floor Initiative. Friedrich Ebert Stiftung.

Gassmann, F. (2011). To what extent does the existing safety net protect the poor. Washington D.C.: The World Bank.

Hagemejer, K. (2009). Can low income countries afford basic social security? In OECD, Promoting pro-poor growth. Social protection (pp. 89110). 
Handa, S., \& Davis, B. (2006). The Experience of Conditional Cash Transfers in Latin America. Development Policy Review, 24(5), 513-536.

Hennicot, J. (2012). Financial Assessment of the National Social Protection Strategy for the Poor and Vulnerable (Draft v.2). Phnom Penh: International Labour Organization.

IEG. (2011). Evidence and Lessons Learned from Impact Evaluations on Social Safety NEts. Washington DC: Independent Evaluation Group, IEG. World Bank, IFC, MIGA.

International Labour Organization. (2012, 06 14). Social Protection Floor Recommendation. Retrieved from http://www.ilo.org/dyn/normlex/en/f?p=NORMLEXPUB:12100:0:: NO::P12100_ILO_CODE:R202

International Labour Organization, \& World Bank. (2015). A shared mission for universal social protection. Concept Note. Geneva.

Li, J., \& O'Donoghue, C. (2013). A survey of dynamic microsimulation models: uses, model structure and methodology. International Journal of Microsimulation, 6(2), 3-55.

Mideros, A. (2012). Ecuador: Defining and measuring multidimensional poverty, 2006-2010. CEPAL Review, 108, 49-67.

Mideros, A. (2014). Régimen del buen vivir y el rol de la protección social no-contributiva para la erradicación de la pobreza. El caso ecuatoriano. Madrid: Congreso Internacional en Gobierno, Administración y Políticas Públicas.

Mideros, A., Gassmann, F., \& Mohnen, P. (2012). Estimation of rates of return of social protection instruments in Cambodia: A case for noncontributory social transfers. Maastricht: Maastricht Graduate School of Governance. 
Ministerio Coordinador de Desarrollo Social. (2017, 04 19). Sistema Integrado de Conocimiento y Estadistica Social del Ecuador. Retrieved from http://www.conocimientosocial.gob.ec/

National Institute of Statistics. (2009). General Population Census of Cambodia 2008. Phnom Penh: Royal Government of Cambodia.

National Institute of Statistics. (2010). Cambodia Socio-Economic Survey 2009. Phnom Penh: Royal Government of Cambodia.

Royal Government of Cambodia. (2011). National Social Protection Strategy for the Poor and Vulnerable. Phnom Penh: Royal Government of Cambodia.

Spadaro, A. (Ed.). (2007). Microsimulation as a tool for the evaluation of public policies: methods and applications. Bilbao: Fundacion BBVA. Szirmai, A. (2012). Proximate, intermediate and ultimate causality: Theories and experiences of growth and development. Maastricht: UNUMERIT Working Paper Series 2012-032.

Tirivayi, N., Knowles, M., \& Davis, B. (2013). The interaction between social protection and agriculture. A review of evidence. Roma: FAO.

UNDP. (2017, 04 19). Human Development Data (1990-2015). Retrieved from http://hdr.undp.org/en/data

UNICEF. (2012). Integrated Social Protection Systems. Enhancing Equity for Children. New York: United Nations Children's Fund.

UNICEF, \& World Bank. (2013). Common Ground: UNICEF and World Bank Approaches to Building Social Protection Systems.

United Nations. (2015). Transforming our world: the 2030 agenda for sustainable development. New York: United Nations.

United Nations. (2015). Transforming our world: the 2030 Agenda for Sustainable Development. New York: United Nations. 
World Bank. (2015). The State of Social Safety Nets. Washington D.C.: The World Bank.

World Bank. (2017, 04 19). World Bank Open Data. Retrieved from http://data.worldbank.org/ 


\section{Chapter 2 - Labour supply: A unitary discrete choice model ${ }^{4}$}

\subsection{Introduction}

The effect of social protection on labour supply is one of the main economic concerns, because non-negative labour effects are desired to foster positive returns. General economic intuition argues that if non-labour income increases, a person is going to work less due to a pure income effect (i.e., the idleness hypothesis). However, it may not be the case for poor persons, because at low levels of income, more leisure has a lower marginal utility than additional income. This paper generates a theoretical framework and provides empirical evidence on the effect of unconditional cash transfers on adult labour supply. We estimate a unitary, discrete choice, labour supply model for the case of the Ecuadorian Bono de Desarrollo Humano (BDH). It is a cash transfer programme, which was introduced in 1998 by the Government of Ecuador. While the BDH is unconditional on labour, it has conditions with regards to children's health care and school attendance. But the realisation of those conditions is not monitored strongly. Because of this, the $\mathrm{BDH}$ is considered to be a cash transfer with soft conditions. The BDH is targeted using a proxy-means test index, and it provides a flat transfer (e.g., 35 USD per month in 2012). ${ }^{5}$ This case is relevant for analysing labour effects of social transfers in developing countries where this kind of instrument is being implemented largely as a strategy to reduce poverty.

\footnotetext{
${ }^{4}$ This paper has been published as: Mideros A. \& O'Donoghue, C. (2015). The Effect of Unconditional Cash Transfers on Adult Labour Supply: A Unitary Discrete Choice Model for the Case of Ecuador. Basic Income Studies, 10(2), 225-255.

${ }^{5}$ In January 2013, 1.2 million households received the BDH, while 594 thousand old-age and 118 thousand disabled persons received a social pension. The transfer was increased to 50 USD per month in 2013 (it was 35 USD per month in 2012), given a total budget of approximately 1 billion USD in 2013 (approximately 1.2\% of GDP). 
The empirical evidence regarding economic effects of social protection is inconclusive. In the case of labour effects, there is agreement on the reduction of child labour, ${ }^{6}$ but in the case of adults, there is still theoretical ambiguity, and it remains as a gap in our knowledge and an empirical question (Alzúa et al, 2013). There are different channels to explain the effects of social transfers on labour supply. First, there is a pure income effect, because the increment in non-labour income may reduce labour supply. Second, the transfer may also help to cover transaction and opportunity costs that increase labour supply, for example, by covering the cost of labour search and caring. Third, conditionalities may enforce behavioural responses. If children have to go to school, it may free up time for parents that was used previously for childcare. Fourth, if child labour is reduced, adults may increase their labour supply to compensate for the reduction in income from child labour. Fifth, spill-over effects may affect non-beneficiary households and the local economy (2013).

Posel et al (2006) found that a person, between 15 and 50 years old, living in a household with a non-contributory pension recipient has a 3.2 percentage point higher probability of employment in South Africa. They relate this effect to the possibility to cover migration costs and increased support from grandmothers to childcare. In the case of Mexico, Skoufias \& Di Maro (2008) exploiting the experimental deign of the cash transfer programme PROGRESA found no significant effect on adult labour force participation and leisure time, but a substantial reduction in poverty.

\footnotetext{
${ }^{6}$ It is broadly accepted that social transfers enhance children's school attendance and reduce child labour (e.g., Bourguignon et al, 2003; Mideros et al, 2013; Edmonds \& Schady, 2009; Barrientos \& Nino-Zarazua, 2010). However, supply side education policies are needed to guarantee these effects.
} 
Foguel \& de Barros (2010) found positive effects of a conditional cash transfer programme on male labour participation in Brazil. Similar results were found by Barrientos \& Villa (2013), who used data from Colombia. They found marginal positive effects on the participation of males and single adults with children and on employment of women in formal jobs. In addition, evidence suggesting no disincentives to work has also been found in Argentina, Uruguay, and Chile (Maurizio \& Vázquez, 2014), and in Ethiopia, Bangladesh (Barrientos \& Nino-Zarazua, 2010), and Cambodia (Mideros et al, 2013). Some negative effects have been found by Fernandez \& Saldarriaga (2014) in Peru. They found a reduction in working hours in the week following the pay date (short-term effect). However, they did not find any significant long-term effect on labour participation.

Finally, Alzúa et al (2013) who compared results from three different experimental evaluations in Mexico, Nicaragua, and Honduras, found no statistically significant effect of social transfers on labour supply, but they found a positive labour supply effect and an increase in wages in some specific cases. Using the same data, Novella et al. (2012) found no significant labour effect in the Honduras, positive effects on working hours of males, but negative effects on female labour participation in Mexico, and negative effects on working hours of males, but no effects on labour participation in Nicaragua.

The rest of the paper is organized as follows: section two discusses the theoretical framework. Section three presents the data and the empirical strategy. Section four presents the results. Final remarks are presented in section five. 


\subsection{Theoretical framework}

Receiving a social transfer increases household disposable income and subsequently affects the labour supply of its members. Following mainstream labour supply theory, it can be argued that social transfers discourage labour due to the income effect. Additional non-labour income promotes more leisure (less work) and more consumption. However, this idea assumes that a person can work as much as she wants, and that leisure is a normal good. These are unlikely assumptions in the case of individuals in poor households.

Fig. 2.1 presents the income effect of an increase in non-labour income. ${ }^{7}$ Panel A shows the general case where an increase in real income due to a non-contributory social transfer moves the budget constraint from $\mathrm{AB}$ to $\mathrm{DE}$ (transfer size is $\mathrm{AD}$, which is equivalent to $\mathrm{BE}$ ), which allows an individual to increase both consumption and leisure, and then to reduce their allocation of labour time ${ }^{8}$ This produces an increase in the level of utility moving from $\mathrm{U}_{0}$ (at point $\mathrm{C}$ ) to $\mathrm{U}_{1}$ (at point $\mathrm{F}$ ).

However, it is reasonable to assume that there is a minimum level of consumption $\left(\mathrm{C}_{\mathrm{min}}\right)$ below which there is not any level of utility (maybe levels of disutility). We believe that there cannot be utility if a person cannot consume a minimum level of basic goods like water, food, and clothing. Even more, it is hard to think of a person who values leisure more than the possibility of additional income, if she cannot satisfy her basic needs. In this case, time allocation will result in a corner solution at the maximum level of possible work-time (minimizing the gap to achieve $\mathrm{C}_{\mathrm{min}}$, with horizontal

\footnotetext{
${ }^{7}$ Although an increase in real wage (labour income) may discourage work due to an income effect, it also encourages labour due to a substitution effect. However, in the case of a noncontributory social transfer there is only an income effect, if the transfer is received independently of labour.

${ }^{8}$ Time is constrained at point A because it is limited, for example, to 24 hours a day.
} 
indifference curves). It is the case of point B in panel B. Then, if a social transfer is enough to reach $\mathrm{C}_{\mathrm{min}}$, it is likely that a person will assign time for leisure by reducing labour by moving to point $\mathrm{H}$ in panel $\mathrm{B}$. On the other hand, if the transfer is not enough to reach $\mathrm{C}_{\min }$, the effect is higher consumption without any change in labour-leisure time assignation, moving to point $\mathrm{E}^{\prime}$ as in panel $\mathrm{C}$.

In addition, access to and opportunities on the labour market may be constrained, because of labour demand limitations, but also due to personal and household conditions (i.e., opportunity and transaction costs). It means a person may not participate in paid-labour as much as she wants or needs. It is the case of panel D, where the budget constraint is restricted to the segment $\mathrm{AC}$ (i.e., it is not possible to allocate more time to labour than that for point C). In this case, the social transfer does not affect labour at all, if $\mathrm{C}_{\min }$ is still not reachable. The result of introducing a social transfer is a movement from point $\mathrm{C}$ to point $\mathrm{G}$.

Finally, if social transfers help individuals to overcome labour constraints by, for example, covering transaction and child care costs, financing labour search, or acquiring productive assets, the final effect may be positive on labour supply. ${ }^{9}$ Although the budget constraint is still restricted without a social transfer (segment $\mathrm{AC}$ in panel $\mathrm{E}$ ), it is not with the transfer (budget constraint becomes $\mathrm{DE}$ ). The result is a movement from point $\mathrm{C}$ to point $\mathrm{H}$ in panel E.

\footnotetext{
${ }^{9}$ Positive labour supply effects are likely to happen when social transfers reduce credit and child care constraints (Barrientos \& Scott, 2008), and when they help to overcome transportation and other transaction costs (Posel et al, 2006). 
Figure 2.1. Income effect on labour supply
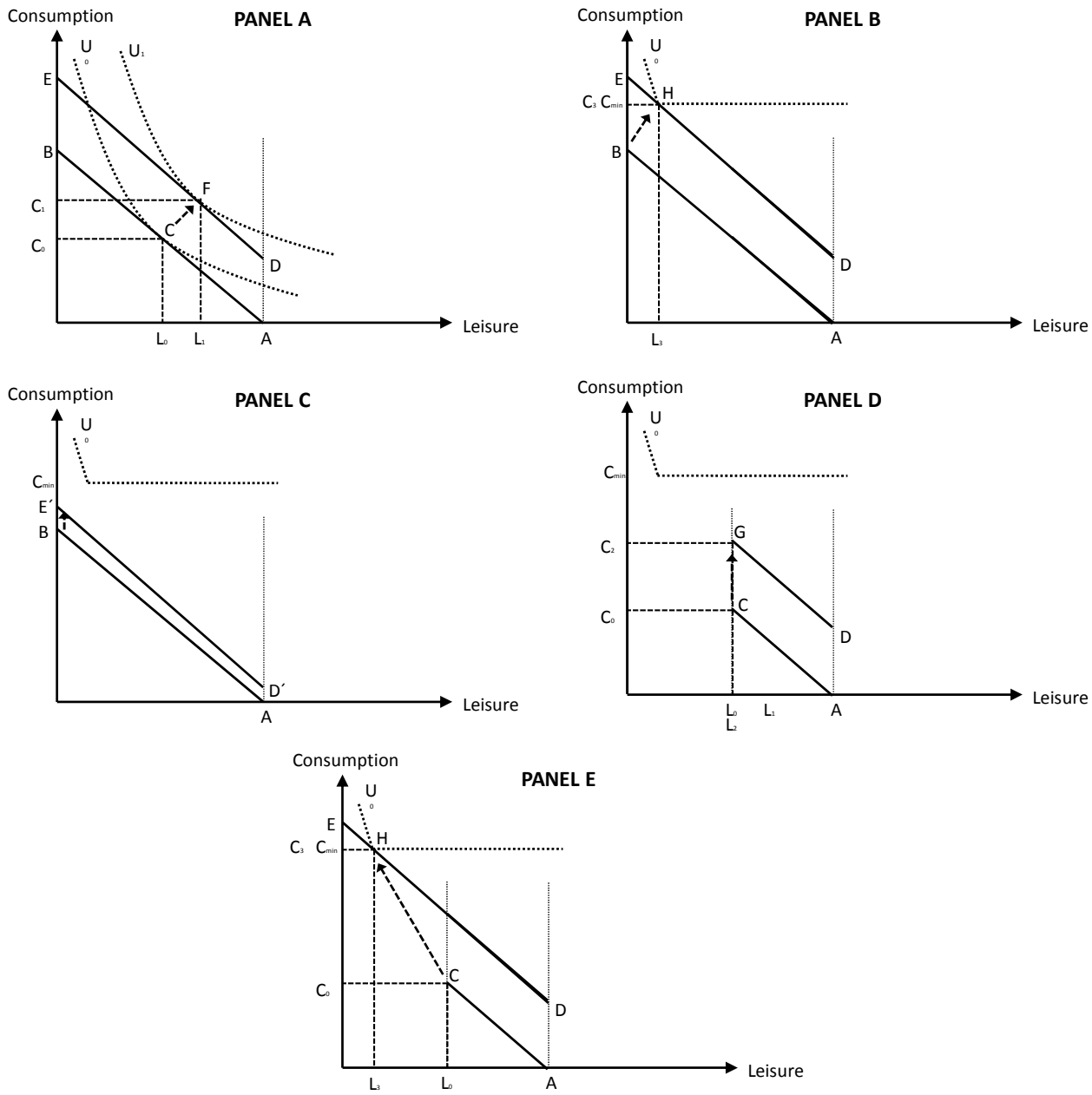

Source: Own elaboration.

Given this theoretical framework, social transfers may affect labour supply negatively in the case of individuals with income/consumption higher than $\mathrm{C}_{\min }$, while producing positive or zero effects in the case of persons with income/consumption below it. In this sense, our hypothesis is that social transfers produce non-negative, labour supply effects in the case of poor adults, because by definition they are below $\mathrm{C}_{\min }$. 


\subsubsection{The unitary discrete choice model}

We rely on an unitary discrete choice model of household labour supply, which has been developed following van Soest (1995) and van Soest et al. (2002); this model is used widely in the literature for similar analyses (e.g., Haan, 2004; Beninger et al., 2007; Kornstad \& Thoresen, 2007; Bloemen, 2010; Breunig \& Gong, 2010; Blundell \& Shephard, 2012; Löffler et al., 2013; Aaberge \& Colombino, 2013; Kabátek et al., 2014; Dagsvik et al., 2014). We assume that labour supply decisions are constrained in the choices of jobs and working hours and, therefore, we require a discrete rather than a continuous labour supply model. Furthermore, as this study aims to analyse the effect of a social transfer delivered to households, we base our model on a household utility function (unitary model) rather than an individual utility function (collective model). ${ }^{10}$

We define household utility as a function of a couple's time allocation and household income. We assume zero leisure $\left(t_{i}^{l s}=0\right)$ in the case of poor households (i.e., those with a level of consumption below $\mathrm{C}_{\min }$ ). Further, given that total time endowment $(T)$ is fixed at a maximum of 24 hours per day, we take paid-labour participation as the decision variable $\left(t_{i}^{l}\right)$ for the household's head $(i=h)$ and her partner $(i=p)$. In this sense, housework (including care-work) time is the complement in the case of poor adults $\left(t_{i}^{h w}=T-t_{i}^{l}\right)$, and a mix of housework and leisure in the case of non-poor adults $\left(t_{i}^{h w}+t_{i}^{l s}=T-t_{i}^{l}\right)$. Paid-labour participation options are defined by the elements of the choice set $(L)$. In addition, we decompose total household income $\left(y_{j}\right)$ into labour income for the household head $\left(w_{h} t_{h}^{l}\right)$ and her partner

\footnotetext{
${ }^{10}$ Although the unitary approach is most commonly used for policy analysis, some scholars argue in favour of a collective model to examine bargaining relations within households (e.g., Blundell et al, 2007; Bloemen, 2009).
} 
$\left(w_{p} t_{p}^{l}\right)$ by considering income from wages $\left(w_{i}\right)$, social transfers $(S t)$, and other non-labour income $\left(Y_{0}\right)$.

The budgeting problem is then described by equation 1 . The utility function $U_{j}($.$) is expected to increase with income, but to decrease with$ labour if household income is equal to or higher than $\mathrm{C}_{\mathrm{min}}$, although it is independent of labour otherwise.

$\max \mathrm{U}_{\mathrm{j}}()=.\left\{\begin{aligned}\left(t_{h}^{l}, t_{p}^{l}, y_{j}-C_{\text {min }}\right), y_{j} & \geq C_{\text {min }} \\ \left(y_{j}-C_{\text {min }}\right), y_{j} & <C_{\text {min }}\end{aligned}\right.$

subject to $y_{j}=w_{h} t_{h}^{l}+w_{p} t_{p}^{l}+S t+Y_{0}$

\subsection{Data and empirical strategy}

We use data from the Urban and Rural National Survey of Employment, Unemployment and Underemployment (ENEMDUR) of the National Institute of Statistics and Censuses (INEC) of Ecuador. Available income information includes, but is not limited to, social transfers. In this paper, we used the round of December 2012. The sample included 73,686 individual observations within 19,840 households; using weights, the sample represented the national population, and it accounted for 14.7 million inhabitants in 3.9 million households.

The BDH is a monthly cash transfer targeted at deprived households based on consumption, using a proxy means test index. ${ }^{11}$ Targeting was done in 2008-2009, and it has not been updated since that time. The BDH is part of household disposable income and, thus it affects poverty and inequality measures. Own estimations showed that the BDH (35 USD per month, in

\footnotetext{
11 The BDH also included pensions for old-age and disabled persons.
} 
2012) reduced the extreme poverty head count by $20.8 \%$, the poverty head count by $9.0 \%$, and the Gini coefficient by nearly $2.0 \%{ }^{12}$

As we mentioned before, the BDH accomplished the basic income's principles of not being conditional on labour and of being paid in cash on a regular basis. Although it is neither universal nor individual, it was targeted based on past household characteristics. But up to the date of our data, there were no entry and exit procedures. Because of these reasons, our study of the BDH's effects on adult labour supply generates insights for the impacts of unconditional basic income programmes.

There are some studies that evaluate the effects of the BDH on different dimensions of wellbeing (see Chapter 1). However, the effect on labour supply and economic returns has not been analysed. An exception is the study of Gonzales-Rozada \& Llerena (2011), who studied the duration of unemployment for those around the eligibility threshold (exploiting a regression discontinuity setting). They found that the BDH may have financed job searchs, which were related to longer periods of unemployment, but with higher future income.

\subsubsection{Descriptive statistics}

To estimate the effect of the BDH on adult labour supply, we used three subsamples, which were restricted to households with non-unemployed adult

\footnotetext{
${ }^{12}$ In December 2012, poverty head count was $27.3 \%$, extreme poverty head count was $11.2 \%$, and the Gini coefficient was 0.477 ; if the $\mathrm{BDH}$ is discounted, these figures increased to $30.0 \%, 14.1 \%$, and 0.486 , respectively. Poverty and extreme poverty lines were 76.35 USD (2.55) and 43.03 USD (1.43) monthly (daily) per-capita, in December 2012. Official poverty lines in Ecuador were estimated in 2006 (using the Life Conditions Survey, ECV-2006) and then they were updated according to the consumer price index (CPI). The extreme poverty line approximated the cost of food needed to cover a defined norm of kilocalories per-person; the poverty line summed non-food goods and services expenses.
} 
members (between 18 and 64 years old). ${ }^{13}$ The first subsample (BDH recipients) included only adults who lived in a $\mathrm{BDH}$ recipient household, which accounted for 1,417 households (2,834 adults, the head and his/her partner). We used this subsample to analyse the effect of the size of the cash transfer among those who received it. The second subsample (all adults) included all households in subsample one, but included? individuals who lived in a non-recipient household. It consisted of 2,853 households $(5,706$ adults, the head and his/her partner). This subsample was used to estimate the effect of receiving the BDH. Finally, the third subsample included single adults, which consisted of 1,086 households/individuals from which 383 households/individuals received the BDH. In total, we had 3,939 householdlevel observations, which included 1,800 BDH recipient households (Table $2.1) .^{14}$

Although the unit of analysis was the household, individual variables were necessary to evaluate time allocation for each adult member. Average household size was 4.4 in the BDH recipients subsample, but it was 3.9 and 2.8 for the all adults and single adults subsamples. Average age was approximately 40 years old. BDH recipient adults had, on average, three years less of education. Women represented $50 \%$ of adults in both subsamples of couples, and they represented $76 \%$ in the single adults subsample. Minority groups (indigenous, afroecuadorians, and montubios) represented a higher percentage in the $\mathrm{BDH}$ recipients subsample, as did those who lived in rural

\footnotetext{
${ }^{13}$ Age range was defined consistent with Ecuadorian legislation. Although legal working age starts at 15 years old, they were excluded to analyse pure effects on adult labour supply. The subsamples included employed, underemployed, and inactive adults. We omitted unemployed households, because their paid-labour choice was not clear.

${ }^{14} \mathrm{We}$ excluded BDH recipient households that had an old-age head of household $(53 \%$ of cases), more than two adults (30\% of the cases), two adults who were not partners $(9 \%$ of the cases), or inconsistent/incomplete data for the model ( $8 \%$ of the cases).
} 
areas. BDH recipient households had on average a higher number of schoolage children ( 6 - 17 years old) and old-age persons, and they had fewer assets and a greater number of unsatisfied basic needs. ${ }^{15}$

Average labour income per month was 174.72 USD, 376.43 USD, and 286.05 USD for BDH recipients, all adults, and single adults subsamples, respectively, which included the inactive with zero income. Labour income per hour was, on average, 1.69 USD, 2.74 USD, and 2.21 USD for those same subsamples, respectively. Almost half (46.4\%) (13.6\%) of the adults in the $\mathrm{BDH}$ recipients subsample were poor (extreme poor), compared to $21.4 \%$ $(6.3 \%)$ in the all adults subsample, and $31.3 \%(13.0 \%)$ in the single adults subsample.

As mentioned, unemployed adults were excluded. They represented a rather low percentage of adults. By excluding them, we omitted 18, 32, and 22 observations from each subsample, respectively. Unemployment was low in all the subsamples, and it ranged between $0.3 \%$ and $2.8 \%$ (Table 2.2). The rate was almost zero for household heads in the couples subsamples, but it was higher in the case of poor single adults. ${ }^{16}$ On the other hand, underemployment affected $40.9 \%, 36.2 \%$, and $48.1 \%$ of adults in the BDH recipients, all adults, and single adults subsamples, respectively. Underemployment was defined by labour-income that was below the

15 Official index of unsatisfied basic needs was calculated by the National Institute of Statistics (INEC) and included: i) low quality of dwelling (floor and walls materials), ii) inadequate access to basic services (water and sewerage), iii) children, 6 - 12 years old, who did not attend school, iv) economic dependence (schooling of the head of house was less than four years, and more than three dependent members per active person), and v) more than three persons per bedroom. A household/person was defined as poor if she was deprived in only one indicator, defined as extreme poor if deprived in two or more, and defined as nonpoor otherwise.

${ }^{16}$ Although unemployment was not a real issue in most of cases, it was rather high in the case of poor single adults. 
minimum wage or working less than 40 hours per week. ${ }^{17}$ In the case of BDH recipient adults, $60 \%$ of underemployed complied with both conditions. This percentage was $59 \%$ and $68 \%$ in the all adults and single adults subsamples, respectively. Underemployment was higher in the case of poor adults in the couples subsamples, because they were probably more willing to take any available job.

Finally, inactivity was higher in the case of adults in a BDH recipient household and for the poor, but it was concentrated among partners, and it was only $1.8 \%$ in the case of household heads. Paid-labour participation rate (including unemployed, underemployed, and employed) for all adults was $83 \%$. In the $\mathrm{BDH}$ recipient subsample, the paid-labour participation rate was $64 \%$, and it was $84 \%$ for single adults. Paid-labour participation was higher for non-poor individuals (70\%) compared to the poor (57\%) among those who received the $\mathrm{BDH}$. For household heads, the participation rate was $98 \%$ in both subsamples of couples, although it was substantially lower for partners in $\mathrm{BDH}$ recipient households (30\%) than in the all adults subsample (68\%). This difference was related to access to other sources of income and with household's needs of care work. Although 96\% of inactive partners in the $\mathrm{BDH}$ recipient households did housework, $64 \%$ of partners in non-recipient households did housework, but landlords and pensioners represented $26 \%$. This indicated that in BDH recipients' households, no participation in the labour market did not mean they had more leisure time, but they did? more housework; in the case of non-BDH recipient households, it was due to more leisure time and to other non-labour-income sources. In the case of inactive single adults, $61 \%$ did housework and $20 \%$ were pensioners.

${ }^{17}$ Consistent with Ecuadorian legislation, the minimum wage was 292 USD per-month in 2012. 
Table 2.1. Descriptive statistics (ENEMDUR - December 2012)

\begin{tabular}{|c|c|c|c|c|c|c|}
\hline \multirow[t]{2}{*}{ Variable } & \multicolumn{2}{|c|}{$\begin{array}{c}\text { BDH } \\
\text { recipients* }\end{array}$} & \multicolumn{2}{|c|}{ All adults** } & \multicolumn{2}{|c|}{ Single adults**** } \\
\hline & Obs. & Mean & Obs. & Mean & Obs. & Mean \\
\hline Household size (number of persons) & 2834 & 4,4 & 5706 & 3,9 & 1086 & 2,8 \\
\hline Age & 2834 & 39,8 & 5706 & 39,4 & 1086 & 42,6 \\
\hline Schooling (Years of education) & 2834 & 6,3 & 5706 & 9,4 & 1086 & 8,7 \\
\hline Sex $($ Female $=1 /$ Male $=0)$ & 2834 & 0,500 & 5706 & 0,500 & 1086 & 0,762 \\
\hline Member $($ Head=1 / Partner $=0)$ & 2834 & 0,500 & 5706 & 0,500 & & 1,000 \\
\hline Married $(\mathrm{Yes}=1 / \mathrm{No}=0)$ & 2834 & 0,995 & & 0,995 & & 0,136 \\
\hline Indigenous $(\mathrm{Yes}=1 / \mathrm{No}=0)$ & 2834 & 0,105 & 5706 & 0,060 & & 0,059 \\
\hline Afroecua & 2834 & 0,056 & 5706 & 0,046 & & 0,063 \\
\hline Mon & 2834 & 0,129 & 570 & 0,062 & & 0,037 \\
\hline$/ \mathrm{No}=0)$ & 2834 & 0,709 & 5706 & 0,830 & & 0,841 \\
\hline Numb & 2834 & 0,208 & 5706 & 0,198 & & 0,116 \\
\hline & 2834 & 0,213 & & 0,185 & & 0,107 \\
\hline & 2834 & 1,035 & 5706 & 0,803 & & 0,566 \\
\hline & 2834 & 0,870 & 5706 & 0,697 & 1086 & 0,744 \\
\hline & 2834 & 0,302 & 5706 & 0,357 & 1086 & 0,137 \\
\hline C & 2834 & 1,698 & 5706 & 1,643 & 1086 & 0,863 \\
\hline Number of old-age (older than 64 years old) & 2834 & 0,053 & 5706 & 0,034 & 1086 & 0,245 \\
\hline Number of unsatisfied basic needs & 2834 & 1,008 & 5706 & 0,499 & 1086 & 0,428 \\
\hline Num & 2834 & 0,885 & 5706 & 1,275 & 1086 & 1,074 \\
\hline Number of telephones & 2834 & 1,416 & 5706 & 2,067 & 1086 & 1,444 \\
\hline Area $($ Rural $=1 /$ Urban $=0)$ & 2834 & 0,677 & 5706 & 0,364 & 1086 & 0,296 \\
\hline Labour income per-month & 2834 & 174,72 & 5706 & 376,43 & 1086 & 286,05 \\
\hline Labc & 2834 & 44,39 & 5706 & 111,91 & 1086 & 116,20 \\
\hline $\mathrm{W}=\mathrm{I}$ & 1793 & 1,69 & 45 & 2,74 & 925 & 2,21 \\
\hline Partn & 2834 & 186,31 & & & & 15,66 \\
\hline Partn & 28 & & & & & 5,51 \\
\hline Household's social transfer (BDH) per-month & 2834 & 37,19 & 5706 & & 1086 & 11,82 \\
\hline $\begin{array}{l}\text { Household's social transfer (BDH) per-month } \\
\text { per-capita }\end{array}$ & 2834 & 9,47 & 5706 & 3,86 & 1086 & 4,48 \\
\hline Household's other non-labour income per-month & 2834 & 4,53 & 5706 & 26,51 & 1086 & 104,08 \\
\hline $\begin{array}{l}\text { Household's other non-labour income per-month } \\
\text { per-capita }\end{array}$ & 2834 & 1,22 & 5706 & 9,51 & 1086 & 43,29 \\
\hline Poor $($ Yes $=1 / \mathrm{No}=0)$ & 2834 & 0,404 & 5706 & 0,214 & 1086 & \\
\hline Extreme poor $(\mathrm{Yes}=1 / \mathrm{No}=0)$ & 2834 & 0,136 & 5706 & 0,063 & 1086 & 0,130 \\
\hline
\end{tabular}

* Adults in households with two adults, who received the BDH, ** Adults in households with two adults, who either received or did not receive the $\mathrm{BDH}, * * *$ Adults in households with a single adult, who either received or did not receive the BDH.

Note: Yes/No and Rural/Urban variables are dummy, and other variables are continuous. Income and transfers are expressed in U.S. dollars (USD). Poverty and extreme poverty lines are 76.35 USD (2.55) and 43.03 USD (1.43) monthly (daily) per-capita, in December 2012. Source: Own calculation based on ENEMDUR - December 2012. 
Table 2.2. \% of persons by paid-labour condition (ENEMDUR - December 2012)

\begin{tabular}{|c|c|c|c|c|c|c|c|c|c|}
\hline \multirow{2}{*}{$\begin{array}{l}\text { Paid-labour } \\
\text { condition }\end{array}$} & \multicolumn{3}{|c|}{ BDH recipients* } & \multicolumn{3}{|c|}{ All adults** } & \multicolumn{3}{|c|}{ Single adults $* * *$} \\
\hline & Non-poor & Poor & All & Non-poor & Poor & All & Non-poor & Poor & All \\
\hline \multicolumn{10}{|c|}{ Household head and partner } \\
\hline Inactive & 30.1 & 42.6 & 35.9 & 11.0 & 38.1 & 16.8 & & & \\
\hline Unemployed & 0.6 & 0.3 & 0.5 & 0.4 & 0.3 & 0.4 & & & \\
\hline Underemployed & 35.5 & 47.1 & 40.9 & 31.7 & 52.4 & 36.2 & & & \\
\hline Employed & 33.7 & 9.9 & 22.7 & 56.9 & 9.2 & 46.7 & & & \\
\hline \multicolumn{10}{|c|}{ Household head } \\
\hline Inactive & 1.4 & 2.2 & 1.8 & 1.9 & 2.3 & 2.0 & 12.0 & 23.1 & 15.6 \\
\hline Unemployed & 0.0 & 0.0 & 0.0 & 0.2 & 0.0 & 0.1 & 0.9 & 6.7 & 2.8 \\
\hline Underemployed & 41.8 & 78.2 & 58.7 & 28.1 & 79.7 & 39.2 & 39.0 & 67.0 & 48.1 \\
\hline Employed & 56.8 & 19.6 & 39.6 & 69.9 & 18.0 & 58.7 & 48.2 & 3.3 & 33.5 \\
\hline \multicolumn{10}{|c|}{ Partner } \\
\hline Inactive & 58.8 & 83.0 & 70.0 & 20.1 & 73.9 & 31.6 & & & \\
\hline Unemployed & 1.3 & 0.7 & 1.0 & 0.6 & 0.7 & 0.6 & & & \\
\hline Underemployed & 29.2 & 16.0 & 23.1 & 35.4 & 25.0 & 33.1 & & & \\
\hline Employed & 10.7 & 0.3 & 5.9 & 44.0 & 0.4 & 34.7 & & & \\
\hline
\end{tabular}

* Adults in households with two adults, (same as before) receiving the BDH, ** Adults in households with two adults, receiving or not the BDH, *** Adults in households with a single adult, receiving or not the $\mathrm{BDH}$

Source: Own calculation based on ENEMDUR - December 2012.

Housework depends on household composition. If there are more dependent persons, then more care work will be necessary. Table 2.3 presents the average dependency ratio by paid-labour condition for different subsamples. In the case of household heads, there was a positive correlation between paid-labour participation and the number of dependents. That is, a person was expected to be more active in paid-activities if there were more members of the household to be cared for, because more resources were needed to satisfy their needs. However, it also meant that the head of the household had the role of generating income. Nevertheless, the behaviour of partners was not clear. For partners in the all adults subsample, it appeared that they reduced labour-participation if the number of dependents increased, which may have been related to a higher role on housework. ${ }^{18}$

\footnotetext{
${ }^{18}$ Kornstad \& Thoresen (2007) estimated that mothers' labour supply could be reduced by $9 \%$ by cash transfers in Norway. In the same way, Breunig \& Gong (2010) found that women living in regions with lack of adequate childcare facilities worked less than their peers who had adequate childcare facilities in Australia.
} 
Table 2.3. Dependency ratio (ENEMDUR - December 2012)

\begin{tabular}{|c|c|c|c|}
\hline Paid-labour participation & Head of house & Partner & Total \\
\hline \multicolumn{4}{|c|}{ BDH recipients } \\
\hline Inactive & 0.31 & 0.49 & 0.49 \\
\hline Active & 0.49 & 0.48 & 0.49 \\
\hline Total & 0.49 & 0.49 & 0.49 \\
\hline \multicolumn{4}{|c|}{ All adults } \\
\hline Inactive & 0.20 & 0.47 & 0.46 \\
\hline Active & 0.43 & 0.40 & 0.42 \\
\hline Total & 0.43 & 0.43 & 0.43 \\
\hline \multicolumn{4}{|c|}{ Single adults } \\
\hline Inactive & 0.58 & & 0.58 \\
\hline Active & 0.61 & & 0.61 \\
\hline Total & 0.60 & & 0.60 \\
\hline
\end{tabular}

Note: Dependency ratio was estimated as the relation between the total number of dependents (children under 18 years old and persons older than 64 years old) and the total number of household members. The difference between head of house and partners was due to the inclusion of single adults.

Source: Own calculation based on ENEMDUR - December 2012.

Based on the theoretical framework presented in section two and these empirical data, we established as hypotheses that the $\mathrm{BDH}$ had non-negative effects on labour participation of household heads, but it may have financed care work done by the partners and single adults. It is important to mention that in the all adults subsample, $96 \%$ of partners were women $(97 \%$ in the $\mathrm{BDH}$ recipients subsample).

\subsubsection{Empirical specification}

For the empirical model, we divided the utility function $\left(U_{j}=V_{j}+\varepsilon_{j}\right)$ of the household into an observable part $\left(V_{j}\right)$ and unobserved characteristics $\left(\varepsilon_{j}\right)$. We assumed that the latter was independent and identically distributed (i.i.d.), which led us to the following distribution assumptions for a conditional logit type probability for household $j$ to choose $t_{j}^{l, k}$ from a discrete and finite set of options: $L=\left\{t_{j}^{l, 1}, \ldots, t_{j}^{l, k}, \ldots t_{j}^{l, L}\right\}$. Furthermore, we assumed that the observed part of the utility function $\left(V_{j}=X_{j}^{\varsigma} \beta\right)$ was linear 
in parameters, with vectors $X_{j}^{s}$ of observable variables and $\beta$ of parameters. In the same way that Haan (2004), Kornstad \& Thoresen (2007), Löffer et al (2013), and Kabátek et al (2014) described this, we defined the logit choice probability as:

$P r_{j}^{k}=\frac{\exp \left(X_{j}^{k} \beta\right)}{\sum_{s=1}^{L} \exp \left(X_{j}^{\prime s} \beta\right)}, t_{j}^{l, k} \in L, s=\{1, \ldots, k, \ldots, L\}$

For households with two adults, we specified 16 alternatives of working hours for the combinations between non-paid labour, part-time, full-time, and more than full-time labour for the household head and her partner, and four choices in the case of households that were headed by single adults (Table 2.4). ${ }^{19}$ Choices with inactive partners were the most frequent, and full-time and full-time-plus options were more common in the case of household heads. Based on empirical data, we used the median number of working hours per week for each choice. Categories were zero hours for no paid-labour, and 28 and 20 hours for part-time paid-labour of household heads and partners, respectively, 24 hours for part-time paid-labour of single adults, 40 hours for full-time paid-labour, and 50 hours for full-time-plus paid-labour. Although using continuous information to create categories may be viewed as a loss of information, it was consistent with the choice of a unitary discrete choice model, and it reduced data problems with respect to the reported number of working hours.

We estimated paid-labour income per hour by a Heckman selection equation (Annex 2.1). Results were used to define household labour income for each possible choice. In this sense, we used paid-labour income and working hours as the choice specific variables, and we interacted them with other household specific characteristics. Income variables (including

\footnotetext{
${ }^{19}$ We excluded households with unemployed adults.
} 
transfers) were presented in USD per week, and we used per capita values to take into account household size. Finally, we used population weights for all the estimations.

Table 2.4. Distribution of households across labour choices

Households with two adults, receiving the BDH

(BDH recipients)

\begin{tabular}{|c|c|c|c|c|c|c|}
\hline & & \multicolumn{5}{|c|}{ Household head } \\
\hline & & $\begin{array}{c}\text { No } \\
\text { paid- } \\
\text { labour }\end{array}$ & $\begin{array}{l}\text { Part-time } \\
\text { paid- } \\
\text { labour }\end{array}$ & $\begin{array}{c}\text { Full-time } \\
\text { paid- } \\
\text { labour }\end{array}$ & $\begin{array}{l}\text { Full-time- } \\
\text { plus paid- } \\
\text { labour }\end{array}$ & Total \\
\hline \multirow{5}{*}{ Partner } & No paid-labour & $\begin{array}{c}9 \\
(1,275)\end{array}$ & $\begin{array}{c}185 \\
(30,184)\end{array}$ & $\begin{array}{c}380 \\
(56,209)\end{array}$ & $\begin{array}{c}439 \\
(70,742)\end{array}$ & $\begin{array}{c}1,013 \\
(158,410)\end{array}$ \\
\hline & Part-time paid-labour & $\begin{array}{c}5 \\
(730)\end{array}$ & $\begin{array}{c}41 \\
(8,352)\end{array}$ & $\begin{array}{c}62 \\
(9,458)\end{array}$ & $\begin{array}{c}77 \\
(10,805)\end{array}$ & $\begin{array}{c}185 \\
(29,345)\end{array}$ \\
\hline & Full-time paid-labour & $\begin{array}{c}7 \\
(993)\end{array}$ & $\begin{array}{c}6 \\
(1,156)\end{array}$ & $\begin{array}{c}70 \\
(10,259)\end{array}$ & $\begin{array}{c}37 \\
(5,814)\end{array}$ & $\begin{array}{c}120 \\
(18,222)\end{array}$ \\
\hline & $\begin{array}{l}\text { Full-time-plus paid- } \\
\text { labour }\end{array}$ & $\begin{array}{c}7 \\
(1,060)\end{array}$ & $\begin{array}{c}13 \\
(1,911)\end{array}$ & $\begin{array}{c}16 \\
(2,955)\end{array}$ & $\begin{array}{c}63 \\
(12,142)\end{array}$ & $\begin{array}{c}99 \\
(18,068)\end{array}$ \\
\hline & Total & $\begin{array}{c}28 \\
(4,058)\end{array}$ & $\begin{array}{c}245 \\
(41,603)\end{array}$ & $\begin{array}{c}528 \\
(78,881)\end{array}$ & $\begin{array}{c}616 \\
(99,503)\end{array}$ & $\begin{array}{c}1,417 \\
(224,045)\end{array}$ \\
\hline
\end{tabular}

Households with two adults, receiving or not the BDH

(All adults)

\begin{tabular}{|c|c|c|c|c|c|c|}
\hline \multicolumn{7}{|c|}{ Household head } \\
\hline & & $\begin{array}{c}\text { No } \\
\text { paid- } \\
\text { labour }\end{array}$ & $\begin{array}{l}\text { Part-time } \\
\text { paid- } \\
\text { labour }\end{array}$ & $\begin{array}{c}\text { Full-time } \\
\text { paid- } \\
\text { labour }\end{array}$ & $\begin{array}{l}\text { Full-time- } \\
\text { plus paid- } \\
\text { labour }\end{array}$ & Total \\
\hline \multirow{5}{*}{ Partner } & No paid-labour & $\begin{array}{c}21 \\
(5,283)\end{array}$ & $\begin{array}{c}189 \\
(31,437)\end{array}$ & $\begin{array}{c}402 \\
(60,267)\end{array}$ & $\begin{array}{c}470 \\
(77,769)\end{array}$ & $\begin{array}{c}1,082 \\
(174,756)\end{array}$ \\
\hline & Part-time paid-labour & $\begin{array}{c}7 \\
(970)\end{array}$ & $\begin{array}{c}86 \\
(17,591)\end{array}$ & $\begin{array}{c}201 \\
(40,662)\end{array}$ & $\begin{array}{c}219 \\
(39,381)\end{array}$ & $\begin{array}{c}513 \\
(98,604)\end{array}$ \\
\hline & Full-time paid-labour & $\begin{array}{c}17 \\
(2,352)\end{array}$ & $\begin{array}{c}44 \\
(9,092)\end{array}$ & $\begin{array}{c}532 \\
(106,829)\end{array}$ & $\begin{array}{c}230 \\
(56,794)\end{array}$ & $\begin{array}{c}823 \\
(175,067)\end{array}$ \\
\hline & $\begin{array}{l}\text { Full-time-plus paid- } \\
\text { labour }\end{array}$ & $\begin{array}{c}13 \\
(2,320)\end{array}$ & $\begin{array}{c}33 \\
(8,975)\end{array}$ & $\begin{array}{c}100 \\
(21,026)\end{array}$ & $\begin{array}{c}289 \\
(68,447)\end{array}$ & $\begin{array}{c}435 \\
(100,768)\end{array}$ \\
\hline & Total & $\begin{array}{c}58 \\
(10,925)\end{array}$ & $\begin{array}{c}352 \\
(67,095)\end{array}$ & $\begin{array}{c}1,235 \\
(228,784)\end{array}$ & $\begin{array}{c}1,208 \\
(242,391)\end{array}$ & $\begin{array}{c}2,853 \\
(549,195)\end{array}$ \\
\hline
\end{tabular}

Households with a single adult, receiving or not the BDH

(Single adults)

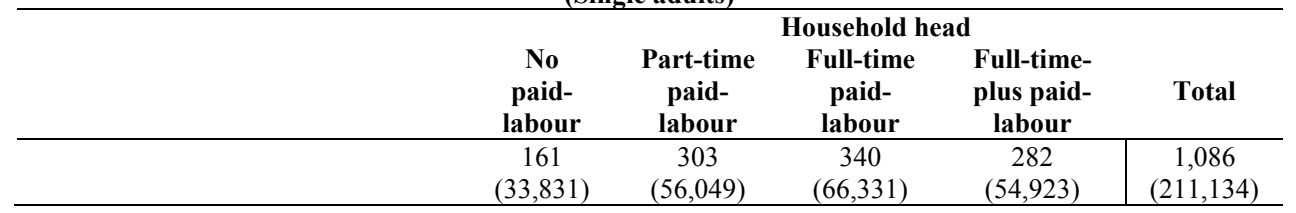

Note: Numbers of households expanded by population weights are presented between brackets.

Source: Own calculation based on ENEMDUR - December 2012. 


\subsection{Results}

\subsubsection{Utility function}

Table 2.5 presents results of a standard conditional logit estimation of the above derived labour supply model (Equation 2). As expected, the average marginal utility of paid-labour income was positive, but decreasing on labour, except for the case of single adults where it was positive only in $23 \%$ of the observations. The marginal utility of paid-labour was positive for household heads and single adults, but it decreased with working hours and paid-labour income. It was consistent with our hypothesis that leisure was not a normal good until a certain level of income/consumption was achieved. On the other hand, marginal utility of paid-labour was negative in the case of partners.

Table 2.5. Reduced utility function coefficients - Equation 2 (labour choice)

\begin{tabular}{|c|c|c|c|c|c|c|}
\hline \multirow{2}{*}{$\begin{array}{c}\text { Variable } \\
\mathrm{y}=\text { Paid-labour income per week per capita }\end{array}$} & \multicolumn{2}{|c|}{$\begin{array}{l}\text { BDH recipients } \\
\text { Coefficient }\end{array}$} & \multicolumn{2}{|c|}{$\begin{array}{l}\text { All adults } \\
\text { Coefficient }\end{array}$} & \multicolumn{2}{|c|}{$\begin{array}{c}\text { Single adults } \\
\text { Coefficient }\end{array}$} \\
\hline & 0,128 & $* * *$ & 0,097 & $* * *$ & $-0,030$ & $* * *$ \\
\hline$y^{\wedge} 2$ & 0,001 & $* * *$ & 0,000 & $* * *$ & 0,000 & $* * *$ \\
\hline$y * 1 j$ & $-0,002$ & *** & $-0,001$ & *** & 0,001 & $* * *$ \\
\hline$y * 1 j$ & $-0,001$ & *** & 0,001 & *** & & \\
\hline $\mathrm{lj}=\overrightarrow{\text { Paid-labour working hours per week of the }}$ & 0,066 & $* * *$ & 0,062 & $* * *$ & 0,056 & $* * *$ \\
\hline $1 \_\mathrm{j}=$ Paid-labour working & $-0,148$ & $* * *$ & $-0,081$ & $* * *$ & & \\
\hline $\overrightarrow{\mathrm{lj} \wedge} 2$ & 0,000 & $* * *$ & $-0,001$ & $* * *$ & $-0,001$ & $* * *$ \\
\hline $1 j^{\wedge} 2$ & 0,002 & $* * *$ & $-0,000$ & **** & & \\
\hline $\overrightarrow{\mathrm{j}} * 1 \mathrm{j}$ & 0,001 & $* * *$ & 0,001 & $* * *$ & & \\
\hline Number of & 224.0 & & 549. & & 52.7 & \\
\hline Pseudo R2 & 0,27 & & 0,1 & & 0,02 & \\
\hline
\end{tabular}

Note: Heteroskedasticity consistent standard errors are between brackets.

$* * *$ Significance at $1 \%, * *$ significance at $5 \%, *$ significance at $10 \%$

Source: Own calculation based on ENEMDUR - December 2012.

Table 2.6 extended the model by including interactions with different household characteristics. We considered the BDH as exogenous, because it was a flat transfer without any condition on household composition or hours worked. However, this assumption can be relaxed with no relevant effects on 
the main results. ${ }^{20}$ Consistent with our hypothesis, the BDH had non-negative effects on the marginal utility of the paid-labour working hours in the case of household heads. The amount of the BDH had no significant effect in the $\mathrm{BDH}$ recipients subsample, but receiving the social transfer had positive but decreasing (on transfer size) labour effects in the all adults subsample. This suggested that negative effects may appear if the transfer was large enough. ${ }^{21}$

However, the BDH generated negative effects on the marginal utility of paid-labour working hours of partners and single adults. Nevertheless, participation of partners and single adults in paid-labour was determined by other household needs (i.e., care work), which was paid by the $\mathrm{BDH} .{ }^{22}$ The marginal utility of paid-labour working hours decreased if the household dependency ratio increased in the case of partners. It was also the case if the number of children under 5 years old increased. However, the effect was lower or not significant if children attended a public nursery, except for single adults. That is, partners allocated more time to childcare. Finally, paid-labour participation of partners and single adults may have been promoted by increasing access to childcare facilities and by the presence of additional caregivers (i.e., old-age persons), because the burden of care work was reduced.

\footnotetext{
${ }^{20}$ To analysis potential endogeneity bias we estimate a linear probability model for paidlabour participation. The difference between the BDH's coefficients in the OLS and the 2SLS (with IV) is not statistically significant. In this sense even assuming endogeneity bias, it does not change the interpretation of our results. The IV procedure to estimate programme participation follows Ponce \& Bedi (2010) by including a third-degree polynomial of the replicated proxy means test index, and the decision rule (It is 1 if the index is below the cutoff of 36.5, and 0 otherwise) in the first stage. Utility function coefficients using an IV approach, to estimate program participation, are lower in magnitude but signs and significance level remains the same.

${ }^{21}$ Using the coefficients of the all adults subsample, we estimated that negative effects occurred at a transfer level of 4.53 USD per week per person (approximately 71 USD per month, for an average household size).

22 This is consistent with evidence found by Kornstad \& Thoresen (2007) and Breuning \& Gong (2010) on the relation between childcare and labour supply. 
Table 2.6. Utility function coefficients - Equation 2 (labour choice)

\begin{tabular}{|c|c|c|c|c|c|c|}
\hline Variable & BDH rec & pients & All ac & & Single a & dults \\
\hline $\mathrm{y}=$ Paid-labour income per week per capita & 0,063 & $* * *$ & 0,035 & **** & $-0,141$ & **** \\
\hline$y^{\wedge} 2$ & 0,000 & $* * *$ & 0,000 & $* * *$ & $-0,001$ & *** \\
\hline$y * 1 j$ & $-0,002$ & $* * *$ & $-0,001$ & $* * *$ & 0,003 & *** \\
\hline$y * 1 j$ & $-0,002$ & $* * *$ & $-0,001$ & $* * *$ & & \\
\hline $\mathrm{lj}=\overrightarrow{\text { Paid-labour working hours per week of the head }}$ & 0,205 & $* * *$ & 0,176 & $* * *$ & 0,104 & $* * *$ \\
\hline $1 \mathrm{j}=$ Paid-labour working hours per week of the partner & $-0,017$ & *** & 0,051 & *** & & \\
\hline $1 \mathrm{j}^{\wedge} 2$ & $-0,002$ & **** & $-0,002$ & *** & $-0,002$ & $* * *$ \\
\hline $1 \mathrm{j}^{\wedge} 2$ & 0,001 & $* * *$ & $-0,000$ & *** & & \\
\hline $1 \mathrm{j} * 1 \mathrm{j}$ & 0,001 & $* * *$ & 0,002 & $* * *$ & & \\
\hline $1 \mathrm{j} *$ other non-labour-income per week per capita & $-0,007$ & *** & $-0,001$ & *** & $-0,002$ & $* * *$ \\
\hline $1 \mathrm{j} *$ social transfer $(\mathrm{BDH})$ per week per capita & 0,000 & & 0,001 & & 0,022 & **** \\
\hline $1 \mathrm{j} *(\text { social transfer }(\mathrm{BDH}) \text { per week per capita })^{\wedge} 2$ & $-0,002$ & $* * *$ & $-0,002$ & *** & $-0,002$ & *** \\
\hline $1 \mathrm{j} * \mathrm{BDH}(\mathrm{Yes}=1 / \mathrm{No}=0)$ & & & 0,032 & $* * *$ & $-0,056$ & $* * *$ \\
\hline $1 \mathrm{j} *$ other non-labour-income per week per capita & 0,000 & & $-0,001$ & $* * *$ & & \\
\hline $1 \mathrm{j} *$ social transfer $(\mathrm{BDH})$ per week per capita & $-0,006$ & $* * *$ & 0,004 & *** & & \\
\hline $1 \mathrm{j} *(\text { social transfer }(\mathrm{BDH}) \text { per week per capita })^{\wedge} 2$ & 0,000 & $* * *$ & $-0,001$ & $* * *$ & & \\
\hline $1 \vec{j} * \mathrm{BDH}(\mathrm{Yes}=1 / \mathrm{No}=0)$ & & & $-0,091$ & *** & & \\
\hline lj*age & 0,002 & $* * *$ & 0,001 & *** & 0,006 & **** \\
\hline $1 \mathrm{j} *$ age ${ }^{\wedge}$ & 0,000 & $* * *$ & 0,000 & *** & 0,000 & *** \\
\hline lj * schooling (years of education) & 0,000 & & $-0,004$ & $* * *$ & $-0,003$ & *** \\
\hline $\mathrm{lj} *$ sex dummy $($ Female $=1 /$ Male $=0)$ & $-0,141$ & *** & $-0,115$ & $* * *$ & $-0,079$ & $* * *$ \\
\hline $1 \mathrm{j} *$ indigenous dummy $(\mathrm{Yes}=1 / \mathrm{No}=0)$ & $-0,030$ & **** & $-0,024$ & *** & $-0,005$ & *** \\
\hline $1 \mathrm{j} *$ afro dummy $($ Yes $=1 / \mathrm{No}=0)$ & $-0,029$ & $* * *$ & $-0,022$ & *** & 0,008 & *** \\
\hline $1 \mathrm{j} *$ montubio dummy $(\mathrm{Yes}=1 / \mathrm{No}=0)$ & $-0,023$ & *** & $-0,020$ & *** & $-0,057$ & *** \\
\hline $1 \mathrm{j} *$ age & 0,002 & *** & 0,005 & *** & & \\
\hline $1 \mathrm{j} * \operatorname{age}^{\wedge} 2$ & 0,000 & $* * *$ & 0,000 & $* * *$ & & \\
\hline $\overrightarrow{\mathrm{l}} \mathrm{j} *$ schooling (years of education) & 0,000 & $* * *$ & 0,001 & *** & & \\
\hline$\vec{j}$ * sex dummy $($ Female $=1 /$ Male $=0)$ & $-0,081$ & *** & $-0,095$ & *** & & \\
\hline $\overrightarrow{1} \mathrm{j} *$ indigenous dummy $(\mathrm{Yes}=1 / \mathrm{No}=0)$ & 0,010 & $* * *$ & 0,037 & *** & & \\
\hline $1 \mathrm{j} *$ afro dummy $($ Yes $=1 / \mathrm{No}=0)$ & 0,008 & *** & 0,004 & *** & & \\
\hline $1 \mathrm{j} *$ montubio dummy $(\mathrm{Yes}=1 / \mathrm{No}=0)$ & $-0,011$ & $* * *$ & $-0,021$ & $* * *$ & & \\
\hline $\overrightarrow{\mathrm{y} * \text { head's age }}$ & 0,001 & $* * *$ & 0,000 & *** & 0,000 & \\
\hline $\mathrm{y} *$ head's age ${ }^{\wedge} 2$ & 0,000 & $* * *$ & 0,000 & *** & 0,000 & ** \\
\hline y * head's schooling (years of education) & 0,003 & **** & 0,003 & *** & 0,010 & *** \\
\hline $\mathrm{y} *$ head's sex dummy $($ Female $=1 /$ Male $=0)$ & 0,025 & *** & 0,029 & *** & 0,012 & *** \\
\hline $\mathrm{y} *$ head's indigenous dummy $(\mathrm{Yes}=1 / \mathrm{No}=0)$ & 0,094 & $* * *$ & 0,016 & $* * *$ & $-0,013$ & **** \\
\hline $\mathrm{y} *$ head's afro dummy $(\mathrm{Yes}=1 / \mathrm{No}=0)$ & 0,016 & $* * *$ & 0,010 & *** & $-0,008$ & *** \\
\hline $\mathrm{y} *$ head's montubio dummy $(\mathrm{Yes}=1 / \mathrm{No}=0)$ & $-0,031$ & *** & $-0,020$ & *** & 0,069 & $* * *$ \\
\hline lj* household dependency ratio & $-0,029$ & $* * *$ & 0,035 & **** & 0,009 & **** \\
\hline $\begin{array}{l}\text { lj * number of children under } 5 \text { attending a public nursery }\end{array}$ & $-0,015$ & *** & $-0,014$ & $* * *$ & $-0,019$ & *** \\
\hline $1 \mathrm{j} *$ number of children under 5 not attending a public nursery & 0,005 & $* * *$ & 0,006 & *** & $-0,010$ & *** \\
\hline $1 \mathrm{j} *$ number of old age persons $(65+)$ & 0,013 & **** & $-0,007$ & *** & 0,022 & *** \\
\hline $1 \mathrm{j} *$ household dependency ratio & $-0,095$ & $* * *$ & $-0,080$ & $* * *$ & & \\
\hline $1 \mathrm{j} *$ number of children under 5 attending a public nursery & $-0,001$ & ** & $-0,001$ & & & \\
\hline $1 \mathrm{j} *$ number of children under 5 not attending a public nursery & $-0,012$ & **** & $-0,006$ & *** & & \\
\hline $1 \mathrm{j} *$ number of old age persons $(65+)$ & 0,029 & **** & 0,034 & *** & & \\
\hline$y *$ number of unsatisfied basic needs & $-0,029$ & **** & $-0,018$ & $* * *$ & $-0,034$ & **** \\
\hline $\mathrm{y} *$ number of televisions & 0,021 & $* * *$ & 0,007 & *** & 0,002 & $* * *$ \\
\hline $\mathrm{y} *$ number of telephones & 0,015 & *** & 0,007 & *** & 0,008 & $* * *$ \\
\hline $\mathrm{y} *$ area dummy $($ Rural $=1 /$ Urban $=0)$ & $-0,005$ & $* * *$ & $-0,009$ & $* * *$ & 0,006 & *** \\
\hline y * parish's poverty by basic needs head count & $-0,044$ & *** & 0,047 & $* * *$ & $-0,122$ & *** \\
\hline lj * parish's poverty by basic needs head count & $-0,036$ & *** & $-0,044$ & *** & 0,057 & *** \\
\hline $1 \mathrm{j}$ * parish's poverty by basic needs head count & $-0,009$ & *** & $-0,038$ & *** & 0,000 & \\
\hline Number of observations & 224.0 & & 549. & & 52.7 & \\
\hline
\end{tabular}

Note: Heteroskedasticity consistent standard errors are between brackets.

$* * *$ Significance at $1 \%, * *$ significance at 5\%, $*$ significance at $10 \%$

Source: Own calculation based on ENEMDUR - December 2012. 
Finally, it has to be noted that the marginal utility of paid-labour working hours was lower for women than for men. This was probably due to women's role as child care-givers, but it was also due to the inequality in paid-labour income against women (Annex 2.1). In this sense, both childcare and gender equity policies may be seen as complements of social transfers, if paid-labour participation is to be promoted.

All these results were consistent with our hypotheses that the BDH did not generate negative labour effects in the case of heads of household. However, the size of the transfer did matter, because if it was large enough, paid-labour disincentives may have been generated. In the case of partners and single adults, we argue that households may be using social transfers to finance childcare.

\subsubsection{Average marginal effects}

We used a multinomial logit equation to estimate average marginal effects (AME) on the probability of choosing a specific paid-labour option. In this case, we assumed the decision of one adult as given. That is, we estimated the effects independently for household heads and partners, and we considered four possible choices (Table 2.7).

Among those adults who received the BDH, an increase of 1 USD (42\% at the mean level) per week per capita on the transfer size increased the probability of no paid-labour by 1.1 and 5.6 percentage points in the case of household heads and partners, respectively. However there was not any significant effect on other choices in the case of household heads, but a reduction of 5.9 percentage points on full-time paid-labour in the case of partners. On the other hand, looking at the all adults subsample, receiving the $\mathrm{BDH}$ reduced the probability of no paid-labour by 2.1 percentage points for 
household heads, and it increased the probability of full-time-paid labour by 9.2 percentage points (but not significantly).

However, the transfer size reduced the positive effect, as an additional 1 USD increased the probability of no paid-labour by 0.6 percentage points. In the case of partners, receiving the $\mathrm{BDH}$ increased the probability of no paidlabour by 34.6 percentage points. Finally, we found that receiving the BDH had no significant effects in the case of single adults. ${ }^{23}$

In the case of partners, if the dependency ratio of the household increased by 0.01 (between $1.7 \%$ and $2.3 \%$ at the mean level), the probability of no paid-labour increased by 0.5 percentage points in the $\mathrm{BDH}$ recipients subsamples, but the effect was not significant for the all adults subsample, and it was negative (reduction of 0.2 percentage points) in the case of single adults (Table 2.8). On the other hand, the presence of an additional old-age person in the household reduced the probability of no paid-labour by 18.4 , 8.3 , and 6.5 percentage points in each subsample, respectively, by increasing the probability of full-time paid-labour by 9.3 and 12.2 percentage points in the $\mathrm{BDH}$ recipients and the all adults subsamples, respectively; the probability of full-time-plus paid-labour increased by 6.6 percentage points in the case of single adults. Finally, the number of children under 5 years old increased the probability of no paid-labour by between 3.4 and 6.4 percentage points in the subsamples of couples, if the children did not attend a public nursery. However, this effect was not significant if the children attended a public nursery. In the case of single adults, one additional child under 5, who

\footnotetext{
${ }^{23}$ In addition to the results presented in this paper, we estimated different models for the probability of paid-labour participation using logit, probit, and linear regressions (with and without IV) for each subsample, and we estimated average treatment effects of the BDH using propensity score matching. In all cases, $\mathrm{BDH}$ had a non-negative effect on participation of household heads and single adults in the labour force, but it had negative effects in the case of partners. All the models can be obtained from the authors upon request.
} 
did not attend a public nursery, increased the probability of no paid-labour by 4.6 percentage points; however, additional estimates showed that this negative labour effect did not happen in the case of men. ${ }^{24}$

All our estimates showed that the BDH did not necessarily generate negative labour supply effects on household heads, but we found positive effects in some cases. However, the amount of the transfer should be defined at an optimal level. From our theoretical framework, we related this effect to the idea that leisure time cannot be considered a normal good in the case of poor individuals, and that a social transfer may help households solve liquidity constraints and cover different transaction costs. Nevertheless, we found negative paid-labour effects for partners and, in some cases, for single adults. BDH may have paid for childcare, because we related this effect to a lack of access to alternative childcare options, and because there was an inequality in paid-labour income against women. If paid-labour participation is to be promoted, social transfers should be complemented by policies that address gender equity and childcare.

\footnotetext{
${ }^{24}$ In the case of household heads, in the subsamples of couples, average marginal effects of the dependency ratio, number of children, and number of old-age persons were not statistically significant for the probability that there was no paid-labour. 
Table 2.7. Average marginal effects of the BDH on paid-labour

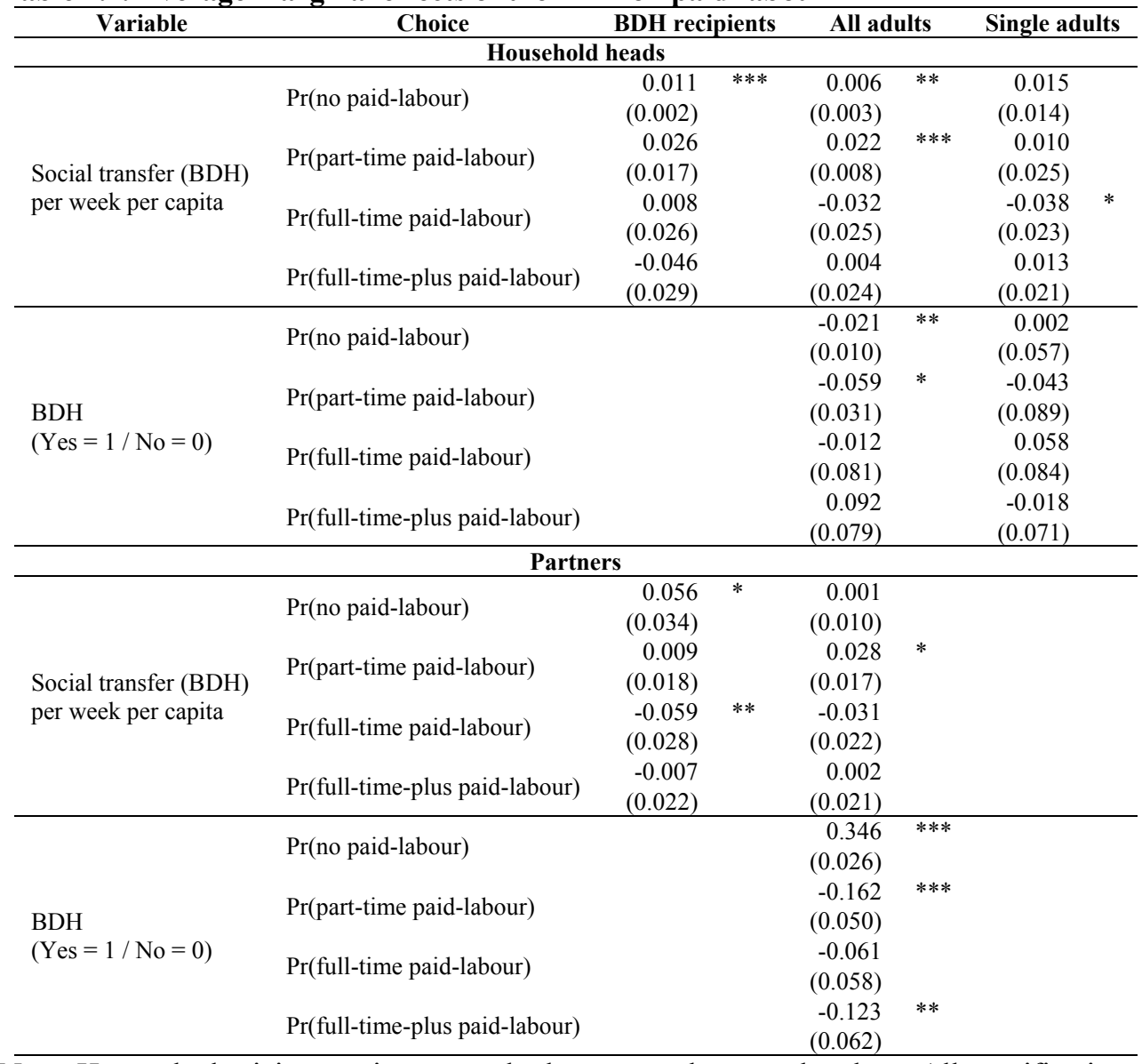

Note: Heteroskedasticity consistent standard errors are between brackets. All specifications included the following explanatory variables (even if not reported): paid-labour income (household head and partner), other non-labour income, age, age square, schooling, sex dummy, ethnic group dummy, household dependency ratio, number of children under 5, number of old-age persons, number of unsatisfied basic needs, assets (number of televisions and telephones), and dummy and parish's head count of poverty by unsatisfied basic needs. $* * *$ Significance at $1 \%, * *$ significance at $5 \%, *$ significance at $10 \%$

Source: Own calculation based on ENEMDUR - December 2012. 
Table 2.8. Average marginal effects on paid-labour (partners)

\begin{tabular}{|c|c|c|c|c|c|c|c|}
\hline \multirow[t]{2}{*}{ Variable } & Choice & \multicolumn{2}{|c|}{ BDH recipients } & \multicolumn{2}{|c|}{ All adults } & \multicolumn{2}{|c|}{ Single adults } \\
\hline & \multirow{2}{*}{$\operatorname{Pr}($ no paid-labour) } & 0.513 & $* *$ & 0.047 & & -0.233 & $* *$ \\
\hline \multirow{7}{*}{$\begin{array}{l}\text { Household } \\
\text { dependency ratio }\end{array}$} & & $(0.225)$ & & $(0.088)$ & & $(0.112)$ & \\
\hline & \multirow{2}{*}{$\operatorname{Pr}$ (part-time paid-labour) } & -0.057 & & -0.110 & & 0.103 & \\
\hline & & $(0.143)$ & & $(0.087)$ & & $(0.242)$ & \\
\hline & \multirow{2}{*}{$\operatorname{Pr}$ (full-time paid-labour) } & -0.323 & $* *$ & 0.163 & * & 0.085 & \\
\hline & & $(0.149)$ & & $(0.087)$ & & $(0.302)$ & \\
\hline & \multirow{2}{*}{$\operatorname{Pr}$ (full-time-plus paid-labour) } & -0.133 & & -0.100 & & 0.044 & \\
\hline & & $(0.123)$ & & $(0.097)$ & & $(0.188)$ & \\
\hline \multirow{8}{*}{$\begin{array}{l}\text { Number of children } \\
\text { under } 5 \text { attending a } \\
\text { public nursery }\end{array}$} & \multirow{2}{*}{$\operatorname{Pr}$ (no paid-labour) } & 0.026 & & 0.011 & & 0.072 & \\
\hline & & $(0.043)$ & & $(0.020)$ & & $(0.044)$ & \\
\hline & \multirow{2}{*}{$\operatorname{Pr}$ (part-time paid-labour) } & -0.016 & & -0.017 & & 0.012 & \\
\hline & & $(0.034)$ & & $(0.035)$ & & $(0.074)$ & \\
\hline & \multirow{2}{*}{$\operatorname{Pr}($ full-time paid-labour) } & 0.001 & & 0.022 & & 0.071 & \\
\hline & & $(0.021)$ & & $(0.030)$ & & $(0.077)$ & \\
\hline & \multirow{2}{*}{$\operatorname{Pr}$ (full-time-plus paid-labour) } & -0.011 & & -0.016 & & -0.155 & $*$ \\
\hline & & $(0.030)$ & & $(0.029)$ & & $(0.089)$ & \\
\hline \multirow{8}{*}{$\begin{array}{l}\text { Number of children } \\
\text { under } 5 \text { not attending } \\
\text { a public nursery }\end{array}$} & \multirow{2}{*}{$\operatorname{Pr}$ (no paid-labour) } & 0.064 & $* *$ & 0.034 & $* * *$ & 0.046 & $*$ \\
\hline & & $(0.028)$ & & $(0.013)$ & & $(0.024)$ & \\
\hline & \multirow{2}{*}{$\operatorname{Pr}$ (part-time paid-labour) } & -0.004 & & -0.029 & & 0.006 & \\
\hline & & $(0.024)$ & & $(0.018)$ & & $(0.035)$ & \\
\hline & \multirow{2}{*}{$\operatorname{Pr}$ (full-time paid-labour) } & -0.037 & $* *$ & 0.028 & & -0.002 & \\
\hline & & $(0.017)$ & & $(0.019)$ & & $(0.027)$ & \\
\hline & \multirow{2}{*}{$\operatorname{Pr}$ (full-time-plus paid-labour) } & -0.023 & & -0.033 & $*$ & -0.050 & \\
\hline & & $(0.015)$ & & $(0.020)$ & & $(0.042)$ & \\
\hline \multirow{8}{*}{$\begin{array}{l}\text { Number of old age } \\
\text { persons }(65+)\end{array}$} & \multirow{2}{*}{$\operatorname{Pr}$ (no paid-labour) } & -0.184 & $* * *$ & -0.083 & $* * *$ & -0.065 & $*$ \\
\hline & & $(0.059)$ & & $(0.028)$ & & $(0.036)$ & \\
\hline & \multirow{2}{*}{$\operatorname{Pr}$ (part-time paid-labour) } & 0.035 & & -0.073 & & -0.040 & \\
\hline & & $(0.043)$ & & $(0.047)$ & & $(0.055)$ & \\
\hline & \multirow{2}{*}{$\operatorname{Pr}$ (full-time paid-labour) } & 0.093 & $* * *$ & 0.122 & $* * *$ & 0.039 & \\
\hline & & $(0.031)$ & & $(0.040)$ & & $(0.040)$ & \\
\hline & \multirow{2}{*}{$\operatorname{Pr}$ (full-time-plus paid-labour) } & 0.055 & & 0.034 & & 0.066 & $*$ \\
\hline & & $(0.036)$ & & $(0.043)$ & & $(0.037)$ & \\
\hline
\end{tabular}

Note: Heteroskedasticity consistent standard errors are between brackets. All specifications included the following explanatory variables (even if not reported): paid-labour income (household head and partner), other non-labour income, social transfers (BDH), the probability of receiving the $\mathrm{BDH}$, age, age square, schooling, sex dummy, ethnic group dummy, number of unsatisfied basic needs, assets (number of televisions and telephones), are dummy and parish's head count of poverty by unsatisfied basic needs.

$* * *$ Significance at $1 \%$, ** significance at 5\%, $*$ significance at $10 \%$

Source: Own calculation based on ENEMDUR - December 2012. 


\subsection{Final remarks}

Social transfers were largely being implemented as a strategy to reduce poverty and inequality. Recent literature provides new analytical frameworks that rely on social transfers as an instrument to generate positive economic returns. However, empirical evidence remains scarce in this field. This study provides a theoretical framework and contributes empirical evidence on the effects of unconditional cash transfers on adult labour supply, which we believe is a key question for understanding the economic effects of social transfers.

Following traditional labour supply theories, it can be argued that a social transfer discourages labour due to an income effect, if we assume that leisure is a normal good. We argue that it is not the case for poor individuals who cannot cover their basic needs. For example, it is difficult to value leisure without sufficient water, food, and clothing. In this sense, social transfers may not generate this type of income effect in the case of poor households. Furthermore, international evidence suggests that there are non-negative labour effects of social transfers.

We estimated a unitary discrete labour supply model using data from Ecuador. Results for the utility function and average marginal effects were consistent with our theoretical framework, and these results proved our hypothesis, because we found that there were non-negative effects of social transfers on household heads labour supply, but it was limited to a certain transfer level. Moreover, we found positive effects that we related to the idea of social transfers that helped poor households solve liquidity constraints and cover different transaction costs. On the other hand, we found negative effects of labour supply on partners (who were mainly women) and single adults, where a social transfer may have paid for childcare, but also because of 
idiosyncratic characteristics and labour market inequality against women. We believe that policies that address gender equity and childcare should complement social transfers if paid-labour participation of partners is a final objective. However, this should be carefully thought out with respect to the wellbeing of children and the freedom of adults to choose the kind of work they prefer.

\subsection{References}

Aaberge, R., \& Colombino, U. (2013). Using a microeconometric model of household labour supply to design optimal income taxes. The Scandinavian Journal of Economics, 115(2), 449-475.

Alderman, H., \& Yemtsov, R. (2012). Productive role of safety nets. Washington D.C.: The World Bank.

Alzúa, M. L., Cruces, G., \& Ripani, L. (2013). Welfare programs and labor supply in developing countries: Expermitental evidence from Latin America. Journal of Population Economics, 26, 1255-1284.

Arnold, C., Conway, T., \& Greenslade, M. (2011). Cash transfers. Department for International Development, DFID.

Barrientos, A. (2012). Social transfers and growth: What do we know? What do we need to find out? World Development, 40(1), 11-20.

Barrientos, A., \& Nino-Zarazua, M. (2010). Effects of non-contributory social transfers in developing countries: A compendium. Geneva: International Labour Organization.

Barrientos, A., \& Scott, J. (2008). Social transfers and growth: A review. BWPI Working Paper.

Barrientos, A., \& Villa, J. M. (2013). Antipoverty transfers and labour force participation effects. BWPI Working Paper, 185. 
Beninger, D., Laisney, F., \& Beblo, M. (2007). Welfare analysis of a tax reform for Germany: A comparison of the unitary and collective models of households labour supply. Journal of Population Economics, 20(4), 869-893.

Bloemen, H. (2010). Income taxation in an empirical collective household labour supply model with discrete hours. Tinbergen Institute Discussion Paper(2010-010/3).

Bloemen, H. G. (2009). An empirical model of collective household labur supply with non-participation. The Economic Journal, 120, 183-214.

Blundell, R., \& Shephard, A. (2012). Employment, hours of work and the optimal taxation of low-income families. Review of Economic Studies(79), 481-510.

Blundell, R., Chiappori, P.-A., Magnac, T., \& Meghir, C. (2007). Collective labour supply: Heterogeneity and non-participation. The Review of Economics Studies, 74(2), 417-445.

Bourguignon, F., Ferreira, F. H., \& Leite, P. G. (2003). Conditional cash transfers, schooling, and child labour: Micro-simulating Brazil's Bolsa Escola program. The World Bank Economic Review, 17(2), 229-254.

Breunig, R., \& Gong, X. (2010). Child care availability, quality and affordability: Are local problems related to maternal labour supplu? Treasury Working Paper(2010-02).

Buser, T., Oosterbeek, H., Plug, E., Ponce, J., \& Rosero, J. (2013). Impactos de quitar el BDH en salud infantil. Mimeo.

Cherrier, C., Gassmann, F., Mideros, A., \& Mohnen, P. (2013). Making the investment case for social protection. Methodological challenges with lessons learnt from a recent study in Cambodia. Working paper 2013/06(2013-06). 
Colombino, U., Locatelli, M., Narazani, E., \& O'Donoghue, C. (2010). Alternative basic income mechanisms: An evaluation exercise with microeconometric model. Basic Income Studies, 5(1).

Dagsvik, J., Jia, Z., Kornstad, T., \& Thoresen, T. (2014). Theoretical and practical arguments for modelling labor supply as a choice among latent jobs. Journal of Economic Surveys, 28(1), 134-151.

Edmonds, E., \& Schady, N. (2009). Poverty alleviation and child labor. NBER Working Paper Series(15345).

Fernandez, F., \& Saldarriaga, V. (2014). Do benefit recipients change their labor supply after receiving the cash transfer? Evidence from the Peruvian Juntos Program. IZA Journal of labor \& Development, 3(2).

Foguel, M. N., \& de Barros, R. P. (2010). The effects of conditional cash transfers programmes on adult labour supply: An empirical analysis using time-series-cross-section sample of brazilian municipalities. Est. Econ. Sao paulo, 40(2), 259/293.

Gonzales-Rozada, M., \& Llerena Pinto, F. (20 de April de 2011). The effects of a conditional transfer program on the labor market: The Human Development Bonus in Ecuador. Mimeo.

Haan, P. (2004). Discrete Choice Labor Supply: Conditional Logit vs. Random Coefficient Models. DIW Berlin, Discussion Papers 394. Harvey, P. (2013). More for less: The job guarantee strategy. Basic Income Studies, 7(2), 3-18.

INEC. (25 de May de 2013). Instituto Nacional de Estadísticas y Censos Proyecciones poblacionales. Obtenido de http://www.inec.gob.ec/estadisticas/index.php?option=com_content\&vi ew $=$ article $\& \mathrm{id}=329 \&$ Itemid $=328 \&$ lang $=$ es 
Jackson, W. (1999). Basic Income and the right to work: A keynesian apporach. Journal of Post Keynesian Economics, 21(4), 639-662.

Kabátek, J., van Soest, A., \& Stancanelli, E. (2014). Income taxation, labour supply and housework: A discrete choice model for Frenc couples. Labour Economics(27), 30-43.

Kornstad, T., \& Thoresen, T. (2007). A discrete choice model for labor supply and childcare. J Popul Econ(20), 781-803.

León, M., \& Younger, S. (2007). Transfer payments, mothers' income and child health in Ecuador. The Journal of Development Studies, 43(6), 1126-1143.

Löffler, M., Peichl, A., \& Siegloch, S. (2013). Discrete choice labor supply models and wage exogeneity. Mimeo.

LoVuolo, R. (2012). Prospects and challenges for the basic income proposal in Latin America. Basic Income Studies, 7(1).

Maurizio, R., \& Vázquez, G. (2014). Argentina: efectos del programa Asignación Universal por Hijo en el comportamiento laboral de los adultos. Revista CEPAL, 113, 121-144.

Mideros, A. (2012). Ecuador: Defining and measuring multidimensional poverty, 2006-2010. ECLAC Review(108), 49-67.

Mideros, A., Gassmann, F., \& Mohnen, P. (2013). Estimation of rates of return on social protection: Making the case for non-contributory social transfers in Cambodia. (2013-063).

Novella, R., Ripani, L., Cruces, G., \& Alzúa, M. L. (2012). Conditional cash transfers, female bargaining power and paternal labour supply. Washington D.C.: IDB Working Paper Series IDB-WP-368. 
Oosterbeek, H., Ponce, J., \& Schady, N. (2008). The impaact of cash transferson school enrolment. Tinbergen Institute Discussion Paper(TI 2008-037/4).

Paxson, C., \& Schady, N. (2010). Does money matter? The effecs of cash transfers on child development in rural Ecuador. Economic Development and Cultural Change, 59(1), 187-229.

Ponce, J. (2008). Education policy and performance. Evaluating the impact of targeted education programs in Ecuador. Maastricht: Shaker Publishing.

Ponce, J., \& Bedi, A. (2010). The impact of a cash transfer program on cognitive achievements: The Bono de Desarrollo Humano of Ecuador. Economics of Education Review(29), 116-125.

Posel, D., Fairburn, J. A., \& Lund, F. (2006). Labour migration and households: A reconsideration of the effects of the social pension on labour supply in South Africa. Economic Modelling, 23, 836-853.

Psacharopoulos, G., \& Patrinos, H. (2002). Returns to Investment in Education: A Further Update. World Bank Policy Research Working Paper(2881).

Schady, N., \& Araujo, M. C. (2008). Cash transfers, conditions, and school enrolment in Ecuador. Economía, 8(2), 43-77.

Schady, N., \& Rosero, J. (2008). Are cash transfers made to women spent like other sources of income? Economics Letters(101), 246-248.

SIISE. (2013). Sistema Integrado de Indicadores Sociales del Ecuador. Recuperado el 25 de May de 2013, de http://www.siise.gob.ec/siiseweb/ Skoufias, E., \& Di Maro, V. (2008). Conditional cash transfers, adult work incentives, and poverty. The Journal of Development Studies, 44(7), 935960. 
Standing, G. (2008). How cash transfers promote the case for basic income. Basic Income Studies, 3(1), 1-30.

Standing, G. (2013). Why a basic income is necessary for a right to work. Basic Income Studies, 7(2), 19-40.

Suplicy, E. M. (2003). Ligitimizing basic income in developing countries:

Brazil, or "the answer is blowin' in the wind". Journal of Post Keynesian Economics, 25(3), 407-424.

Tirivayi, N., Knowles, M., \& Davis, B. (2013). The interaction between social protection and agriculture. A review of evidence. Rome: Food and Agriculture Organization of the United Nations (FAO).

UNICEF. (2012). Integrated Social Protection Systems. Enhancing Equity for Children. New York: United Nations Children's Fund.

Van Parijs, P. (2004). Basic income: A simple and powerful idea for the twenty-first century. Politics \& Society, 32(1), 7-39.

van Soest, A. (1995). Structural Models of Family Labor Supply. A Discrete Choice Approach. The Journal of Human Resources, 30(1), 63-88.

van Soest, A., Das, m., \& Gong, X. (2002). A structural labour supply model with flexible preferences. Journal of Econometrics(107), 345-374.

World Bank. (7 de July de 2013). The World Bank Indicators. Obtenido de http://data.worldbank.org/indicator/NY.GNP.PCAP.CD 


\section{Annex 2.1. Paid-labour income (Heckman selection equation)}

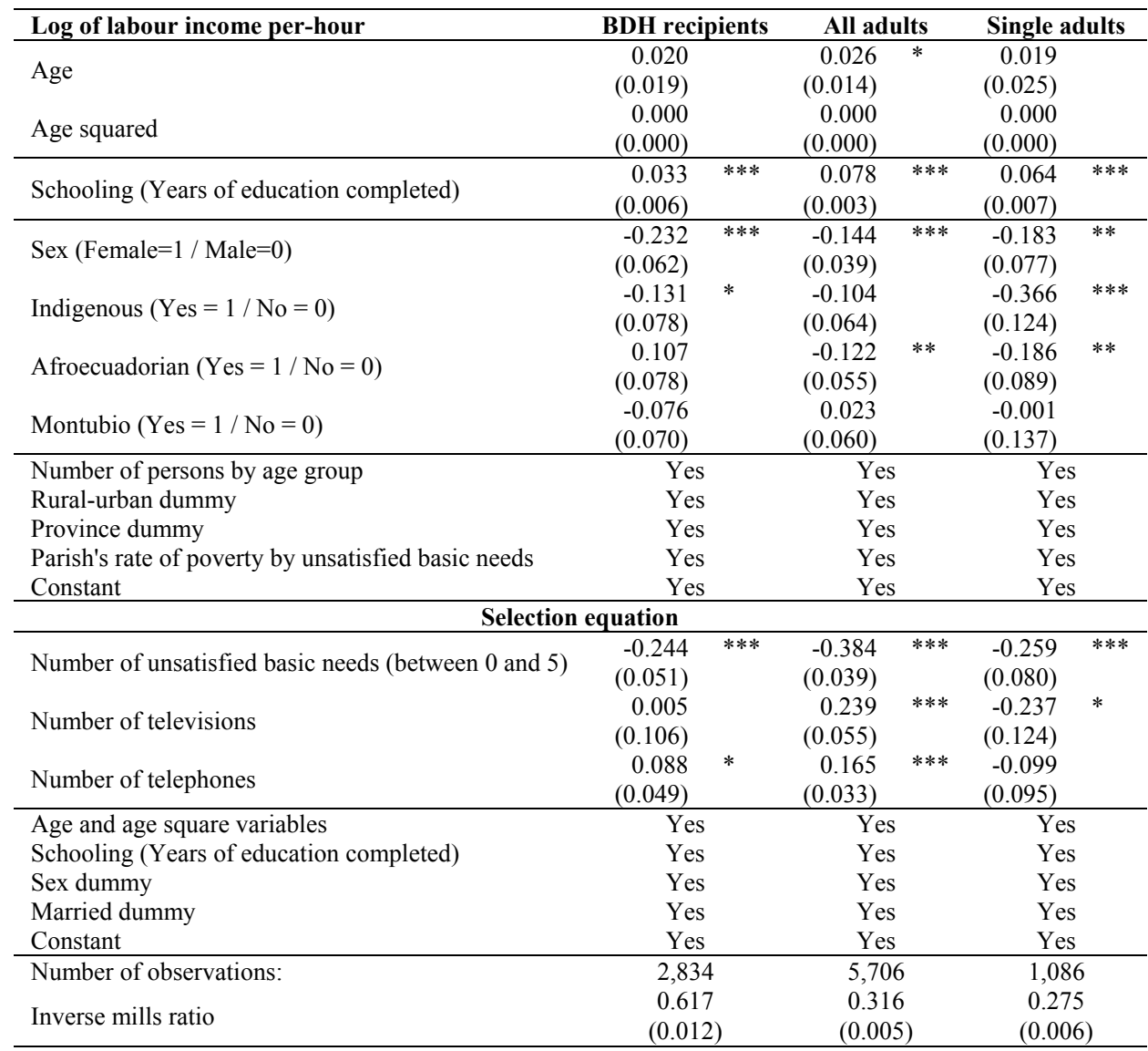

Interpretation: Combining the final and selection equations, an additional year of education was related to an $8.1 \%$ higher labour income per-hour for all adults. This result was at international levels (Psacharopoulos \& Patrinos, 2002). However, the return was lower in the case of single adults $(6.4 \%)$ and the BDH recipients $(3.3 \%)$ subsamples, which may have been related to both lower quality of education and lower access to labour opportunities. Results also showed gender disparities against women. Women earned 12\% $-29 \%$ less income from labour.

Note: Heteroskedasticity consistent standard errors (between brackets) were estimated and they clustered at the parish level. We used columns two and three to estimate labour-income for the labour supply model.

$* * *$ Significance at $1 \%, * *$ significance at $5 \%, *$ significance at $10 \%$

Source: Own calculation based on ENEMDUR - December 2012. 


\section{Chapter 3 - Accumulation of human capital: A cost- effectiveness analysis ${ }^{25}$}

\subsection{Introduction}

Social transfers are being broadly implemented in developing countries, because of their direct effect on reducing poverty, decreasing inequality, and achieving social outcomes. There is a large literature on these effects. ${ }^{26}$ However, social transfers also reduce the intergenerational transmission of poverty by promoting the accumulation of human capital. The long-term economic effects of investments in social transfers are a key argument in favour of such transfers. New theory and evidence is needed to understand fully the potential and the limits of social transfers to foster inclusive economic development and to contribute to the eradication of poverty, as one of the sustainable development goals.

There are relatively new analytical frameworks that link social transfers and economic growth (see for example Sadoulet et al (2001)), Barrientos \& Sabates-Wheeler (2009), Barrientos (2012), Alderman and Yemtsov (2012), Tirivayi et al (2013), Thome et al (2013), and Mideros et al (2016)). At the micro level, social transfers help poor households escape credit constraints; second, social transfers provide certainty and security in consumption and promotes higher investments in physical and human capital; and third, social

\footnotetext{
25 The author is grateful for comments from colleagues of the research group on poverty, public policy, and inclusive innovation at the Maastricht Graduate School of Governance, UNU-MERIT \& Maastricht University, especially those from Cathal O'Donoghue, Franziska Gassmann, and Andrea Franco. An earlier version of this paper was presented at the European Meeting of the International Microsimulation Association, Maastricht (23-24 October 2014). ${ }^{26}$ See for example Samson et al (2004), Barrientos (2005), Barrientos and Scott (2008), Barrientos and Niño-Zarazua (2010), Barrientos et al (2010), Arnold et al (2011), IEG (2011), Barrientos (2012), UNICEF (2012), Alderman \& Yemtsov (2012), Mideros et al (2012), Tirivayi et al (2013), World Bank (2015), and Bastagli et al (2016).
} 
transfers improve households' resource allocation by financing opportunity and transaction costs (Barrientos, 2012). Moreover, social transfers influence growth at the micro level by overcoming market failures such as credit constraints and information assymmetries (Alderman \& Yemtsov, 2012). In this sense, social transfers help poor households to accumulate and protect assets, to increase entrepreneurial activitiesm and to increase human capital and productivity. In this perspective Mideros et al. (2012) linked social transfers with an analytical framework of socio-economic development that was proposed by Szirmai (2012). They discussed how social transfers affected development outcomes by reducing poverty and inequality and fostering human development, and how ultimate sources of growth and development were affected by increasing social cohesion, intermediate sources by social policies, and proximate sources by increasing human capital and productive assets.

However, despite the relevance of this literature on the expansion of social transfers to promote reductions in poverty and inequality, and to foster inclusive economic development, empirical evidence remains scarce (Cherrier, Gassmann, Mideros, \& Mohnen, 2013). Moreover, it is well known that the effect of social transfers depends on its design, level of benefit, and target groups (Notten \& Gassmann, 2008). This paper concentrates on the effect of social transfers on the accumulation of human capital, because it is both a final outcome and a driver of productive capacity. ${ }^{27}$ Although Mincer (1974) was responsible for the analysis of the relationship between the distribution of earnings and human capital, Becker \& Thomes (1986) and Becker \& Thomas (1994) argued that in the case of poor households,

\footnotetext{
${ }^{27}$ Human capital is related to skills, knowledge, and effort and its relationship to productive capacity (Sen, 1997). 
underinvestment was a result of "poverty traps" that were related to household size, high opportunity costs, and credit constraints; they also described the role of investments in children on intergenerational mobility. Similarly, Heckman \& Mosso (2014) argued the importance of early childhood conditions on social mobility.

Social transfers may support poor households in measuring their investments in human capital, because they increase households' disposable income directly (i.e., income effect). But the way that social transfers are designed also promote behavioural changes (i.e., non-income effect). Nevertheless, effects on human capital were also conditioned on the level of coverage, quality of service, and the elimination of barriers to access health, education, and sanitation services (Mideros, Gassmann, \& Mohnen, 2012). Under this perspective, the research question this paper aims to answer is whether and to what extent social transfers foster long-term accumulation of human capital. The contribution goes in two directions. First, the effect of social transfers on accumulation of human capital over the lifecycle was explored empirically; this is a topic that the literature has not completely covered yet. Then, alternative designs of social transfers were evaluated by their cost-effectiveness. Despite the fact that human capital is multidimensional, the scope of this study was limited to the income effect of social transfers on schooling, measured by the years of education that a person obtained throughout a certain period of her life, as a proxy for human capital. A dynamic cohort microsimulation model was developed for a cohort of 5 year old children, simulating 14 years as a discrete period, to calculate the level of human capital accumulated up to the age of 18 . The model used agespecific survival rates that were estimated from official demographic projections and equations for school attendance and marriage status, and 
social transfers, education policies, household income, educational achievements (i.e., grade promotion) were exogenous. Data were obtained from the Ecuadorian National Survey of Employment, Unemployment and Underemployment (ENEMDU) of the National Institute of Statistics and Censuses (INEC) which provides necessary information about individuals, households, and social transfers.

The rest of the paper is organized as follows. Section two discusses the theoretical framework to link social transfers with accumulation of human capital. Section three presents the model and discusses the data and the parameters. A cost-effectiveness analysis of policy options is discussed in section four. Final remarks are elaborated in section five.

\subsection{The theory of accumulation of human capital}

In the "theory of life earnings", Rosen (1976) defined earnings as a function of the stock of human capital, and the decision to invest in human capital was based on the optimization of life-cycle earnings. Similarly, Heckman (1976) believed that accumulation of human capital resulted in a deferred-income stream with costs incurred early in life and returns harvested later. He argued that human capital was "embodied in the human agent and is productive both in the market and in its own production" (1976, p. S12). This idea is consistent with Rosen (1976) in the sense that schooling is valuable, because it provides marketable skills, but it also increases the efficiency to acquire new skills. In this sense, both scholars established that the accumulation of human capital is a decision that is related to the future expected returns of such an investment. In general, the learning production function (i.e., accumulation of human capital) is defined as a function of the stock of human capital and the 
time devoted to its accumulation, and its main cost is earnings that are forgone (i.e., opportunity cost).

Mincer (1974) was responsible for the analysis of the relationship between the distribution of earnings and human capital; later, he? others? expanded the analysis to the estimation of rates of return and the analysis of investment in human capital. Human capital can be accumulated by on-thejob training (e.g., learning new skills or perfecting old ones), which is expected to increase labour productivity and wages. In this case, it is the firm (or employer) who invests time and resources as they hope for future higher output. However, the investment cost is paid by the employee if the effect on productivity is portable by the worker (i.e., general training that can be used on a different firm) or by the employer if it is not (specific training). A second source of accumulation of human capital is investment in schooling, where forgone earnings (opportunity cost) is a major cost of such an investment. Finally, other knowledge, information, and skills can also be considered as human capital to the extent that they have a return on earnings. Similarly, investments to improve emotional and physical health, and motivation, also promote accumulation of human capital, because they are related closely to productivity and earnings (Becker, 1975).

The theory of investment in human capital states that its most important determinants are the rate of return and the investment cost. Becker (1975), who used a wealth maximization model, showed that investments in human capital declined with age for two main reasons. First, the number of periods and the present value of future returns declined with age. Second, the investment costs increased with age and the level of human capital already accumulated, due to higher forgone earnings. In addition, more time spent on accumulation of human capital is expected at any age if the model is extended 
to include a direct effect of human capital on the utility function, instead of only on labour productivity. Regarding incentives to invest, Becker (1975) argued that investments in human capital had a sizable liquidity premium, because they were rather illiquid; on top of that, these kinds of investments suffer from high uncertainty (e.g., ability and length of life). Finally, the investment theory of human capital indicates that it is difficult to borrow funds, because human capital cannot be offered as collateral. This argument was used to explain the underinvestment in education and health (Becker, 1975). In addition, in the case of poor households, underinvestment can be seen as a result of "poverty traps" that is related to household size, high opportunity costs, and credit constraints (Becker \& Tomes, 1986) (1994).

With respect to private rates of return on education, Hartog \& Oosterbeek (2007) summarized the empirical literature. Globally, the average return of an additional year of education on earnings was 5\%-15\%. They found also that marginal returns declined during school years. Differences between countries, the authors argued, can be explained by forces in the labour market (i.e., supply and demand), but by differences in the school system, financial assistance, types of education, individual ability, and family background (Hartog \& Oosterbeek, 2007). With respect to the latter, almost all studies have shown that children of rich and well-educated parents tended to receive more schooling and, hence, had a higher income after their education; one of the reasons that poor families received less schooling was because they faced credit constraints to finance the education of their children (Plug, 2007). In this perspective, Becker \& Thomes (1986) (1994) stated that the role of investments in children was that of intergenerational mobility. Similarly, Heckman \& Mosso (2014) argued for the importance of early childhood conditions on social mobility. 
On the other hand, the social rate of return on education may be different than the private return if it is not equal to the increase in productivity (e.g., if institutions compress the wage structure) or if education produces externalities. Social return would be higher than the private return if the education level of others increases the productivity of the individual, but also if a higher education level affects mortality, criminal activity, and other valuable outcomes (Lindahl \& Canton, 2007). From this perspective, the notion of human capital is included in models of endogenous economic growth, which emphasises its role as a driver of economic capacity. For example, Romer concluded that "an economy with larger total stock of human capital will experience faster growth" (Romer, 1990, p. S99), and "in the absence of feasible policies that can remove the divergence between social and private returns to research, a second-best policy would be to subsidize the accumulation of human capital" (1990, p. S99). Similarly, Lucas (1988) included human capital in a model of economic growth to account for how human capital affected current economic capacity and how the allocation of time affected accumulation of human capital. In his model, human capital increased individual productivity (i.e., internal effect), but it also generated spillovers (i.e., external effects). The latter remained invisible or visible only at the aggregate level. Lindahl \& Canton (2007) summarized empirical studies of the social rate of return on education. Long-term returns were superior to short-term effects, and social returns might have been slightly higher than the private returns. However, the empirical evidence was inconclusive.

In addition, human capital also affected entrepreneurship (i.e., selfemployment), which was seen as an engine of economic capacity, because it promoted competition, innovation, and job creation. Indeed, higher human 
capital fostered these benefits, which justified public investments. Empirical studies showed that education increased entrepreneurs' performance, with a rate of return of $6.1 \%-14.2 \%$, which was higher than the private rates of return of employees (e.g., 14.2\% compared to $10.7 \%$ in the case of the Unites States). One explanation for these findings was that education helped individuals solve capital constraints to start up a business (van der Sluis \& van Praag, 2007).

Based on these reasons, arguments in favour of education subsidies included positive externalities of education (increasing the social rate of return), financial market failures and merit, or public goods. Jacobs (2007) analysed the effects of taxation and education policies on accumulation of human capital. Although progressive taxes on labour income discouraged investments in human capital, because of a reduction in the rate of return, capital income taxes and education subsidies encouraged formation of human capital. ${ }^{28}$ In the case of poor households, it was necessary to take into account the particularity of opportunity and transportation costs and credit and information constraints. And this is where social transfers can make a difference to promote investments on human capital.

\subsubsection{Social transfers and investments in human capital}

Social transfers provide additional secure income to poor households, which affects their consumption and investment patterns. Social transfers reduce constraints on households' budgets, which allows them to consume more goods and services of any kind, such as nutritious food, health care, and

\footnotetext{
${ }^{28}$ Labour income taxes and education subsidies affect forgone earnings, future earnings, and education costs, which are main determinants of investment decisions to build human capital, and capital income taxes reduce (increases) incentives to save in financial (human) form (Jacobs, 2007). 
education. In the case of education, for example, social transfers help households pay fees, materials, and transportation costs. Moreover, because poverty and income insecurity "lead to distortions in inter-temporal resource allocation, forcing a focus on current consumption in preference to investment" (Barrientos, 2012, p. 15), social transfers help households pay opportunity costs, such as the potential labour income of school age members. Finally, social transfers may include conditionalities of human capital to promote non-income effects on school attendance, health care, and other dimensions of human capital. Nevertheless, it has to be realized that effects on human capital are conditioned on the level of coverage, quality of service, and the elimination of different access barriers to health, education, and sanitation services (Mideros, Gassmann, \& Mohnen, 2012).

Empirical evidence regarding the effect of social transfers on human capital includes effects on health and education. Although the role of health on accumulation of human capital and its returns is beyond the scope of this paper, it is important to mention that for poor individuals, having an additional and secure income also promotes healthy behaviour and access to health care services. For instance, Arnold et al. (2011) presented evidence of improvements in food consumption due to social transfers in Ethiopia, an increase in food consumption of approximately $165 \%$ in Bolivia; approximately $75 \%$ of the transfers was spent on food in Malawi. In Ecuador, Schady and Rosero (2008) found an increase in the consumption in food of $1.9-4.3 \%$. Similarly, the World Bank (2015) reported improvements in food consumption, diet diversity, and food security in Zambia.

Social transfers also contributed to an improvement in child nutrition. Agüero et al. (2007) found a gain in expected average height of $3.5 \mathrm{~cm}$ in South Africa. Arnold et al. (2011) showed a reduction in malnutrition that 
was 1.7 times greater than the national trend in Nicaragua, and they found a decline in starvation of $19 \%-48 \%$ in Lesotho. UNICEF (2012) documented an increase in height of $0.12 \mathrm{~mm}$ in children after 10 weeks in Bangladesh, and they found a gain in children's weight of $0.58 \mathrm{~kg}$ in Colombia. Barrientos and Scott (2008) found that health visits increased by 18\%, and Arnold et al. (2011) showed that immunisation of children in Peru increased by $30 \%$, and immunisation coverage increased $45 \%-98 \%$ in Bangladesh. Moreover, they showed reductions in the incidence of illness by $12.5 \%$ in Malawi, a decrease in diarrhoea by $10.5 \%$ in Colombia, and a decrease in maternal mortality by 11\% in Mexico. The World Bank (2015) also reported positive effects on child nutrition for Bangladesh and Uganda. In addition, Bastagli et al. (2016) summarized evidence from 41 studies on the positive effects of cash transfers on dietary diversity, malnourishment, and health services in Latin America, Sub-Saharan Africa, South Asia, and East Asia Pacific.

In education, which is the focus off this paper, Bastagli et al. (2016) provided an extensive literature review of the links and effects of social transfers on education, where they analysed school attendance, test scores, and cognitive and problem-solving skills. By reviewing 42 studies, Bastagli et al. (2016) reported that most of studies showed positive effects for boys and girls on school attendance and reduction in absenteeism. For example, Schady and Araujo (2008) found an increase in school enrolment of $10 \%$ in Ecuador. Similar results for school enrolment were found Pakistan (11\%), Malawi (5\%), and Cambodia (30 \% ) (Arnold et al., 2016), and they also found a reduction in the incidence of absences and drop outs of $20 \%$ and $63 \%$, respectively, in Brazil. The World Bank (2015) also reported a reduction in the drop-out rate in Cambodia, and improvements in cognitive outcomes in Nicaragua. Similarly, there was an increment in the probability of completing 
high school of 4 -8 \% in Colombia (UNICEF (2012). However, Bastagli et al. (2016) also reported some studies where no effect was found, and they related this to the baseline enrolment rate and the size of the social transfer. It is intuitive that "programmes in countries with lower baseline enrolment/attendance may deliver larger impacts compared to countries in which baseline enrolment is high" (Bastagli, et al., 2016, p. 75), because there is more room for improvement. In addition, if there is not enough supply of educational services, any kind of effect can be expected. In the case of transfer size, the authors found that if it was not enough to cover opportunity costs, there may be no effect especially on higher educational levels (Bastagli, et al., 2016).

School attendance can be related intuitively to a direct income effect that helps poor households overcome demand side barriers (e.g., financial constraints), but the effect of social transfers on test scores and cognitive development is less clear, because they are mainly related to other social and environmental factors that include quality of educational services (i.e., supply side policies). However, some effects may be expected when social transfers promote more regular school attendance, and increases "in household expenditure result in better food security and nutritional status of children, which in turns may also positively affect child's cognitive ability and child's efficiency of learning while in school in the long term" (Bastagli, et al., 2016, p. 75). Additionally, information campaigns and conditionality, which are often implemented together with social transfers, may promote behavioural changes on how parents raise their children (Bastagli, et al., 2016). In any case, the effects of social transfers on these variables have not been evaluated thoroughly, but results are not conclusive (Barrientos \& Nino-Zarazua 
(2010), Arnold et al. (2011), IEG (2011), World Bank (2015), and Bastagli et al. (2016).

Even more, positive effects on cognitive development occur under specific conditions that are related to complementary policies, socioeconomic context, and age range. For example, in a randomized experiment in Nicaragua, Macours et al. (2012) found a positive effect on an index of cognitive and socio-emotional outcomes of 0.12 and 0.08 standard deviations after nine and 24 months, respectively, in a conditional cash transfer programme called Atencion a Crisis. However, the impact was unlikely to be related to the cash component alone, but to the synergy with information on the importance of health and education that promotes permanent behavioural changes in child-rearing practices. In the case of the Ecuadorian Bono de Desarrollo Humano (BDH) cash transfer programme, Paxson \& Schady (2010) found an improvement in child development of 0.18 standard deviations among the poorest quartile in rural areas together with an improvement of haemoglobin levels, although no effects were found for less poor children. The authors relate the latter with the small size of the transfer, which may not have made a difference in the case of relatively wealthy children. Similar positive effects on the poorest have been found in Argentina and Bolivia (Paxson \& Schady, 2010). In the case of Uganda, Gilligan et al. (2013) found no effect for 60-83-month old children, but they found positive effects in the case of children aged 54-71 months. The effects were consistent with higher food consumption, lower prevalence of anaemia, and participation in Early Childhood Development centres.

Bastagli et al. (2016) reported larger effects for conditional cash transfers than for unconditional transfers, especially for girls, younger children, and lower ability children, based on studies in Morocco (Benhassine 
et al., 2013), Burkina Faso (Akresh, de Walque, \& Kazianga, 2013), and Malawi (Baird, Mcintosh, \& Olzer, 2011). (Barrera-Osorio, Bertrand, Linden, $\&$ Perez-Calle, 2008) found that conditionality on school graduation rather than just school attendance increased attendance by $5 \%$ in Colombia. Conditional cash transfers targeted to young women in Malawi reduced early marriage, teenage pregnancy, and self-reported sexual activity (Baird et al. (2010).

In the case of transfer size, results are inconclusive. However, transfer size may be more relevant in the case of unconditional cash transfers, which depend on the pure income effect, than in the case of conditional cash transfers where conditionality imposes an additional price effect (Bastagli, et al., 2016). Also, "tying the transfer schedule to critical moments of the school year decision cycle can have an impact, especially on enrolment" (Bastagli, et al., 2016, p. 118). In addition, Villa (2014) found that a longer exposure to Colombia's Familias en Accion conditional cash transfer programme led to a higher accumulation of human capital and higher school registration rates. Moreover, Fernald et al. (2008) (2009) found that the combined effect of longer exposure and higher cash transfer size was positive and significant for cognitive development results. Finally, Bastagli et al. (2016) reported inconclusive evidence regarding the gender of the head of household. Although a higher positive effect was found for female-headed households in Nicaragua, the opposite was found in Indonesia. Results on school attendance was more related to opportunity costs and access to information than with the gender of the adult who received the transfer.

The evidence is conclusive that social transfers enhance investments in human capital of poor households. However, the effect depends on the base line situation, conditionality with regard to attending school, targeting 
particular groups (e.g., girls, rural children, and specific age group), transfer size, and duration of exposure. Moreover, there is still a gap regarding the final effect; that is, how much human capital will a child accumulate throughout the life cycle if she received a social transfer. In the following sections, a dynamic cohort microsimulation model was developed to estimate accumulation of human capital (measured by years of education). Then, the model is used for a cost-effectiveness analysis of the accumulative effect of different social transfer designs.

\subsection{The model}

Microsimulation is being applied increasingly to analyse economic and social policies on individuals and households (Merz, 1993). It is "the process of imitating the behaviour of system patterns as a goal-oriented model experiment to investigate the impacts of different alternatives [on microunits]" (Merz, 1993, p. 2). Li and O’Donoghue (2013) presented a survey of microsimulation models. A first distinction is between "static" and "dynamic" models. The former are used mainly to evaluate distributional effects, and the latter allow individual units to change over time. Moreover, dynamic cohort models simulate a single cohort over their lifetime, and population models follow a population cross-section over a certain period of time (Li \& O'Donoghue, 2013). Among other uses, cohort microsimulation models have been applied to evaluate the effect of economic and social policies over the lifetime of an individual on income distribution (e.g., Baldini (2001)), public pensions (e.g., Geyer and Steiner (2010)), and cohort earnings (e.g., van de Ven (2006)).

In this paper a dynamic cohort microsimulation model was developed to evaluate the effect of social transfers on accumulation of human capital, 
which was measured by the years of education (i.e., schooling) accumulated by a person throughout her life. The model was based on four equations. First, being married was estimated based on the age $(t)$-gender $(g)$-area $(a)$ specific probability to get married, the effect of receiving a social transfer $(b d h)$, and the educational level (Equation 1). Receiving a social transfer (i.e., policy design) was included in the model as a dummy variable. Second, school attendance was estimated based on the age $(t)$-gender $(g)$-area $(a)$ specific probability to attend to school, but adjusted on the social transfer's amount received ( $\left.b d h \_p c\right)$, past behaviour (i.e., school delay), and marriage status (Equation 2). Past behaviour $\left(\right.$ past $\left._{i, t}\right)$ was equal to $t-\left(5+\right.$ schooling $\left._{i, t}\right)$. Third, accumulation of human capital was measured for each individual $(i)$ at a specific age $(t)$, based on the previous level of schooling (at $t-1)$ plus an additional year, if the individual attended school in the previous year times the grade $(d)$ - area $(a)$ specific probability to be promoted (Equation 3). Finally, the model considered demographic changes (i.e., ageing) by adjusting weights using age-specific survival rates (Equation 4).

$$
\begin{array}{lr}
\text { married }_{i, t}=\operatorname{Pr}\left(\text { marriage }_{t, g, a}+\left(\alpha * b d h_{i, t}\right)+\left(\beta * \text { schooling }_{i, t-1}\right)\right. & \text { (Equation 1) } \\
\text { attendance }_{i, t}=\operatorname{Pr}\left(\text { attendance }_{t, g, a}+\left(\gamma * b d h_{p c_{i, t}}\right)+\left(\delta * \text { past }_{i, t}\right)+(\rho *\right. & \\
\text { married } \left._{i, t}\right) & \text { (Equation 2) } \\
\text { schooling }_{i, t}=\text { schooling }_{i, t-1}+\left(\text { attendance }_{i, t-1} * \operatorname{Pr}\left(\text { promotion }_{d, a}\right)\right. & \text { (Equation 3) } \\
\text { weight }_{i, t}=\text { weight }_{i, t-1} * \text { survival }_{t-1} & \text { (Equation 4) }
\end{array}
$$

The model was kept as simple as possible to highlight the effects of interest. Although it meant that we accepted strong "everything else constant" type of assumptions, they did not affect comparisons between different scenarios of social transfers $(\mathrm{BDH})$, which was the aim of this paper. 
Exogenous variables that included the probabilities of attendance, marriage, and promotion, and average marginal effects $(\alpha, \beta, \gamma, \delta, \rho)$, were calculated empirically for Ecuador in the rest of this section. Policy options (i.e., social transfer design) are discussed in the next section.

\subsubsection{Data and variables}

The empirical analysis used pooled data from the Ecuadorian National Survey of Employment, Unemployment and Underemployment (ENEMDU) with rounds in December from 2009 to 2013 of the National Institute of Statistics and Censuses (INEC), which provided necessary information about individuals, households, and social transfers. ${ }^{29}$ The ENEMDU is a national representative survey; it included population weights that were used for all the estimates and regressions. The ENEMDU included information about the Ecuadorian social transfer called "Bono de Desarrollo Humano" (BDH). It pays a flat cash transfer to poor households that is independent of labour conditions and the number of household members. The BDH transferred 35 USD per month to each eligible household between 2009 and 2012, and 50 USD since 2013. Recipient households were identified in 2009 by a proxymean test called the "RS index" (Registro Social index). It was a multivariate welfare indicator that was estimated by non-linear principal components analysis with a value between 0 and 100. The eligibility threshold was estimated as a proxy of the consumption poverty line at a value of 36.50 . The BDH applied soft-conditionality (i.e., recipients were informed about the conditionality, but it was not monitored strongly) that was related to school

\footnotetext{
${ }^{29}$ Pooled data from the rounds of December between 2009 and 2013 were used to estimate average coefficients to avoid potential cyclical effects.

64
} 
attendance and heath care. The transfer mainly targeted poor households with children.

Pooled data from 2009-2013 included 99,616 observations of individuals 5 -18 years old, of which $38.7 \%$ received the BDH. Almost all children of primary education age (i.e., 6 -11 years old) attended school, although the rate was lower among pre-school age children (i.e., 5 years old). The rate of school attendance decreased during secondary education (i.e., 12 -18 years old). Children who received the BDH (i.e., poor and vulnerable households) had a lower probability of attending school, regardless of their age. Further, the decline in school attendance at age of secondary education was higher for them. In addition, males and rural children had lower probabilities of attending school than females and urban children; is evidence is consistent with the accumulated level of human capital (i.e., schooling, measured by the years of education). On average, at the age of 18, urban females achieved 11.0 years of education, followed by urban males (10.6), rural females (9.7), and rural males (9.1). Moreover, those who received the BDH had accumulated lower human capital than the remainder of individuals that we sampled (Table 3.1 and 3.2).

School delay measures the difference between the educational level a child should achieve at a specific age and her actual level of schooling. It was close to 1 year (i.e., on average, a child has one year less education than what she should have for her age) up to 8 years old. This delay was mainly because of low enrolment in pre-school education, which is not compulsory in Ecuador. Later, it increased with age, which may have been related to children having to repeat a year of school, and because some of them dropped out of school. The major increments in school delay occurred after the age of 16, which corresponded to upper secondary education and tertiary education. 
School delay had a cumulative effect on school attendance, especially at older ages, because it reduced a child fit to her peers (Table 3.3).

For economic status, we used four monthly, per-capita income brackets for each household: extremely poor (less than 37.64 USD), moderately poor (37.6-66.78 USD), vulnerable (66.78- 133.56 USD), and middle-\&-upper class (higher than 133.56 USD). Extreme poverty and poverty thresholds were based on official poverty lines of prices in 2009, but the threshold between vulnerable and middle class- $\&$-upper was equivalent to two times the poverty line, as proposed by Lopez-Calva \& Ortiz-Juarez (2011). School attendance increased with income, especially for males and older ages. All these figures were used to parametrize the model in the next section to account for age, gender, and socio-economic specific conditions (Table 3.4, Table $3.5)$. 


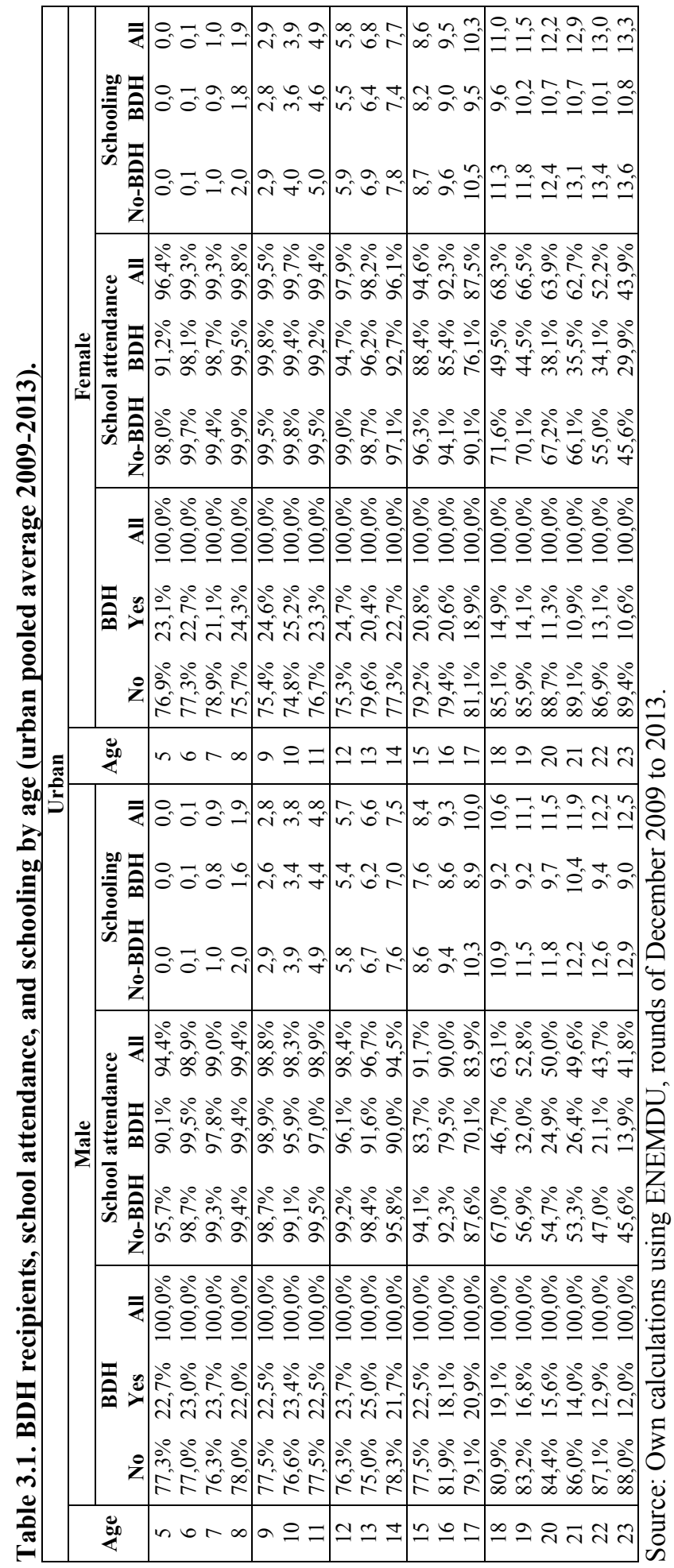




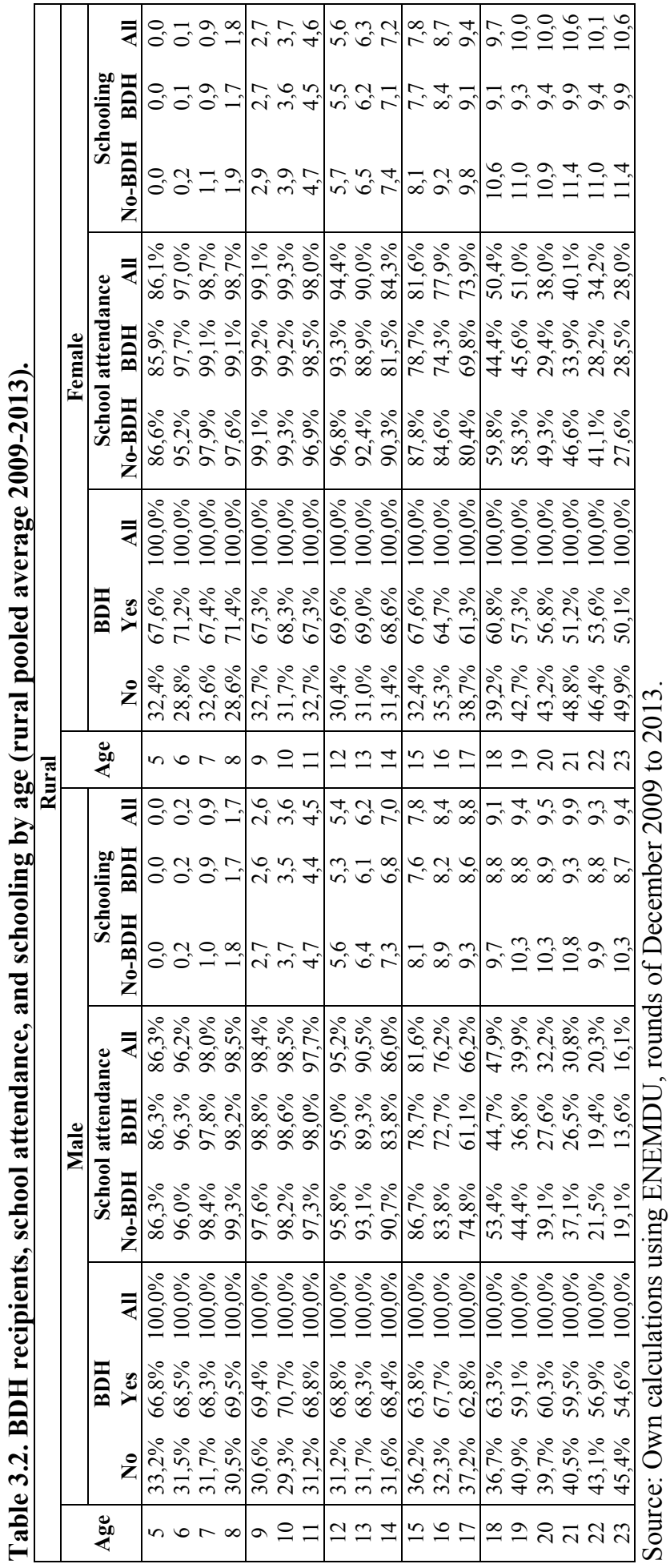


Table 3.3. School delay and marriage by age (pooled average 2009-2013).

\begin{tabular}{|c|c|c|c|c|c|c|c|c|c|}
\hline \multicolumn{10}{|c|}{ Urban } \\
\hline \multirow{3}{*}{ Age } & \multicolumn{4}{|c|}{ Male } & \multirow{3}{*}{ Age } & \multicolumn{4}{|c|}{ Female } \\
\hline & \multicolumn{2}{|c|}{ School delay } & \multicolumn{2}{|c|}{ Married } & & \multicolumn{2}{|c|}{ School delay } & \multicolumn{2}{|c|}{ Married } \\
\hline & No-BDH & BDH & No-BDH & BDH & & No-BDH & BDH & No-BDH & BDH \\
\hline 5 & 0,0 & 0,0 & $0,0 \%$ & $0,0 \%$ & 5 & 0,0 & 0,0 & $0,0 \%$ & $0,0 \%$ \\
\hline 6 & 0,9 & 0,9 & $0,0 \%$ & $0,0 \%$ & 6 & 0,9 & 0,9 & $0,0 \%$ & $0,0 \%$ \\
\hline 7 & 1,0 & 1,2 & $0,0 \%$ & $0,0 \%$ & 7 & 1,0 & 1,1 & $0,0 \%$ & $0,0 \%$ \\
\hline 8 & 1,1 & 1,4 & $0,0 \%$ & $0,0 \%$ & 8 & 1,0 & 1,2 & $0,0 \%$ & $0,0 \%$ \\
\hline 9 & 1,1 & 1,4 & $0,0 \%$ & $0,0 \%$ & 9 & 1,1 & 1,2 & $0,0 \%$ & $0,0 \%$ \\
\hline 10 & 1,1 & 1,6 & $0,0 \%$ & $0,0 \%$ & 10 & 1,0 & 1,4 & $0,0 \%$ & $0,0 \%$ \\
\hline 11 & 1,1 & 1,6 & $0,0 \%$ & $0,0 \%$ & 11 & 1,0 & 1,4 & $0,0 \%$ & $0,0 \%$ \\
\hline 12 & 1,2 & 1,6 & $0,0 \%$ & $0,0 \%$ & 12 & 1,1 & 1,5 & $0,1 \%$ & $0,0 \%$ \\
\hline 13 & 1,3 & 1,8 & $0,0 \%$ & $0,0 \%$ & 13 & 1,1 & 1,6 & $0,0 \%$ & $0,0 \%$ \\
\hline 14 & 1,4 & 2,0 & $0,0 \%$ & $0,0 \%$ & 14 & 1,2 & 1,6 & $0,1 \%$ & $0,6 \%$ \\
\hline 15 & 1,5 & 2,4 & $1,2 \%$ & $0,4 \%$ & 15 & 1,3 & 1,8 & $1,3 \%$ & $2,0 \%$ \\
\hline 16 & 1,6 & 2,4 & $1,6 \%$ & $1,0 \%$ & 16 & 1,4 & 2,0 & $2,3 \%$ & $1,3 \%$ \\
\hline 17 & 1,7 & 3,1 & $1,4 \%$ & $4,4 \%$ & 17 & 1,6 & 2,5 & $4,1 \%$ & $3,2 \%$ \\
\hline 18 & 2,1 & 3,8 & $2,5 \%$ & $6,5 \%$ & 18 & 1,7 & 3,4 & $4,3 \%$ & $6,0 \%$ \\
\hline 19 & 2,5 & 4,8 & $3,6 \%$ & $9,1 \%$ & 19 & 2,3 & 3,8 & $7,4 \%$ & $6,1 \%$ \\
\hline 20 & 3,2 & 5,3 & $4,9 \%$ & $6,8 \%$ & 20 & 2,6 & 4,3 & $7,3 \%$ & $7,7 \%$ \\
\hline 21 & 3,8 & 5,6 & $5,7 \%$ & $13,6 \%$ & 21 & 2,9 & 5,3 & $6,9 \%$ & $13,5 \%$ \\
\hline 22 & 4,4 & 7,6 & $9,4 \%$ & $10,1 \%$ & 22 & 3,6 & 6,9 & $10,1 \%$ & $11,8 \%$ \\
\hline 23 & 5,1 & 9,0 & $8,5 \%$ & $19,2 \%$ & 23 & 4,4 & 7,2 & $11,5 \%$ & $13,3 \%$ \\
\hline \multicolumn{10}{|c|}{ Rural } \\
\hline \multirow{3}{*}{ Age } & \multicolumn{4}{|c|}{ Male } & \multirow{3}{*}{ Age } & \multicolumn{4}{|c|}{ Female } \\
\hline & \multicolumn{2}{|c|}{ School delay } & \multicolumn{2}{|c|}{ Married } & & \multicolumn{2}{|c|}{ School delay } & \multicolumn{2}{|c|}{ Married } \\
\hline & No-BDH & BDH & No-BDH & BDH & & No-BDH & BDH & No-BDH & BDH \\
\hline 5 & 0,0 & 0,0 & $0,0 \%$ & $0,0 \%$ & 5 & 0,0 & 0,0 & $0,0 \%$ & $0,0 \%$ \\
\hline 6 & 0,8 & 0,8 & $0,0 \%$ & $0,0 \%$ & 6 & 0,8 & 0,9 & $0,0 \%$ & $0,0 \%$ \\
\hline 7 & 1,0 & 1,1 & $0,0 \%$ & $0,0 \%$ & 7 & 1,0 & 1,1 & $0,0 \%$ & $0,0 \%$ \\
\hline 8 & 1,2 & 1,3 & $0,0 \%$ & $0,0 \%$ & 8 & 1,1 & 1,3 & $0,0 \%$ & $0,0 \%$ \\
\hline 9 & 1,3 & 1,4 & $0,0 \%$ & $0,0 \%$ & 9 & 1,1 & 1,3 & $0,0 \%$ & $0,0 \%$ \\
\hline 10 & 1, & 1,5 & $0,0 \%$ & $0,0 \%$ & 10 & 1,1 & 1,4 & $0,0 \%$ & $0,0 \%$ \\
\hline 11 & 1,3 & 1,6 & $0,0 \%$ & $0,0 \%$ & 11 & 1,3 & 1,5 & $0,0 \%$ & $0,0 \%$ \\
\hline 12 & 1,4 & 1,7 & $0,3 \%$ & $0,1 \%$ & 12 & 1,3 & 1,5 & $0,0 \%$ & $0,2 \%$ \\
\hline 13 & 1,6 & 1,9 & $0,0 \%$ & $0,1 \%$ & 13 & 1,5 & 1,8 & $0,1 \%$ & $0,2 \%$ \\
\hline 14 & 1,7 & 2,2 & $0,0 \%$ & $0,0 \%$ & 14 & 1,6 & 1,9 & $0,4 \%$ & $0,8 \%$ \\
\hline 15 & 2,0 & 2,4 & $1,0 \%$ & $1,1 \%$ & 15 & 1,9 & 2,3 & $0,7 \%$ & $1,1 \%$ \\
\hline 16 & 2,1 & 2,8 & $1,4 \%$ & $1,0 \%$ & 16 & 1,8 & 2,6 & $2,7 \%$ & $2,2 \%$ \\
\hline 17 & 2,7 & 3,4 & $1,7 \%$ & $3,5 \%$ & 17 & 2,2 & 2,9 & $4,5 \%$ & $3,6 \%$ \\
\hline 18 & 3,3 & 4,2 & $4,4 \%$ & $3,8 \%$ & 18 & 2,4 & 3,9 & $6,3 \%$ & $5,3 \%$ \\
\hline 19 & 3,7 & 5,2 & $6,2 \%$ & $6,0 \%$ & 19 & 3,1 & 4,7 & $8,5 \%$ & $9,5 \%$ \\
\hline 20 & 4,7 & 6,1 & $6,6 \%$ & $13,0 \%$ & 20 & 4,1 & 5,6 & $9,8 \%$ & $7,5 \%$ \\
\hline 21 & 5,2 & 6,7 & $8,2 \%$ & $7,3 \%$ & 21 & 4,7 & 6,1 & $7,8 \%$ & $8,4 \%$ \\
\hline 22 & 7,1 & 8,2 & $12,8 \%$ & $11,2 \%$ & 22 & 6,0 & 7,6 & $12,9 \%$ & $12,7 \%$ \\
\hline 23 & 7,7 & 9,3 & $12,5 \%$ & $20,8 \%$ & 23 & 6,6 & 8,1 & $17,2 \%$ & $9,4 \%$ \\
\hline
\end{tabular}

Source: Own calculations using ENEMDU, rounds of December 2009 to 2013. 


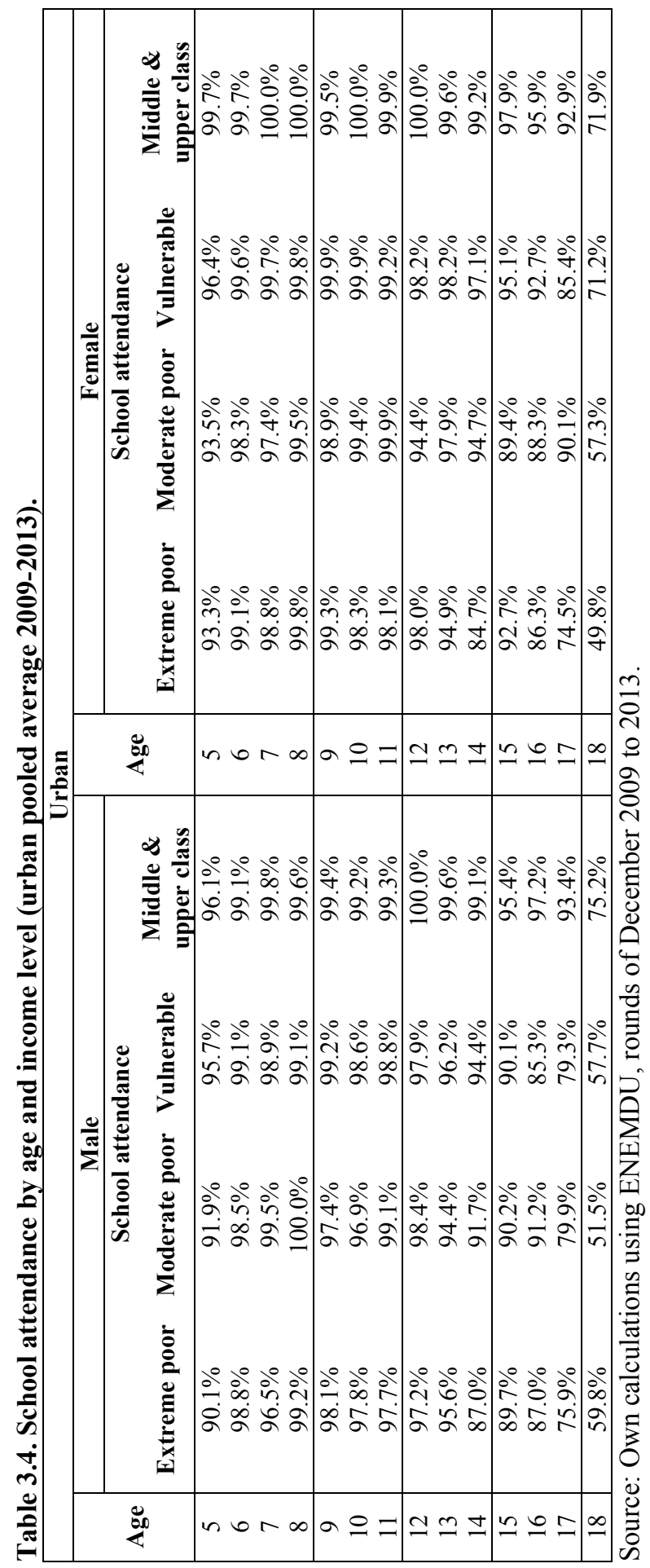




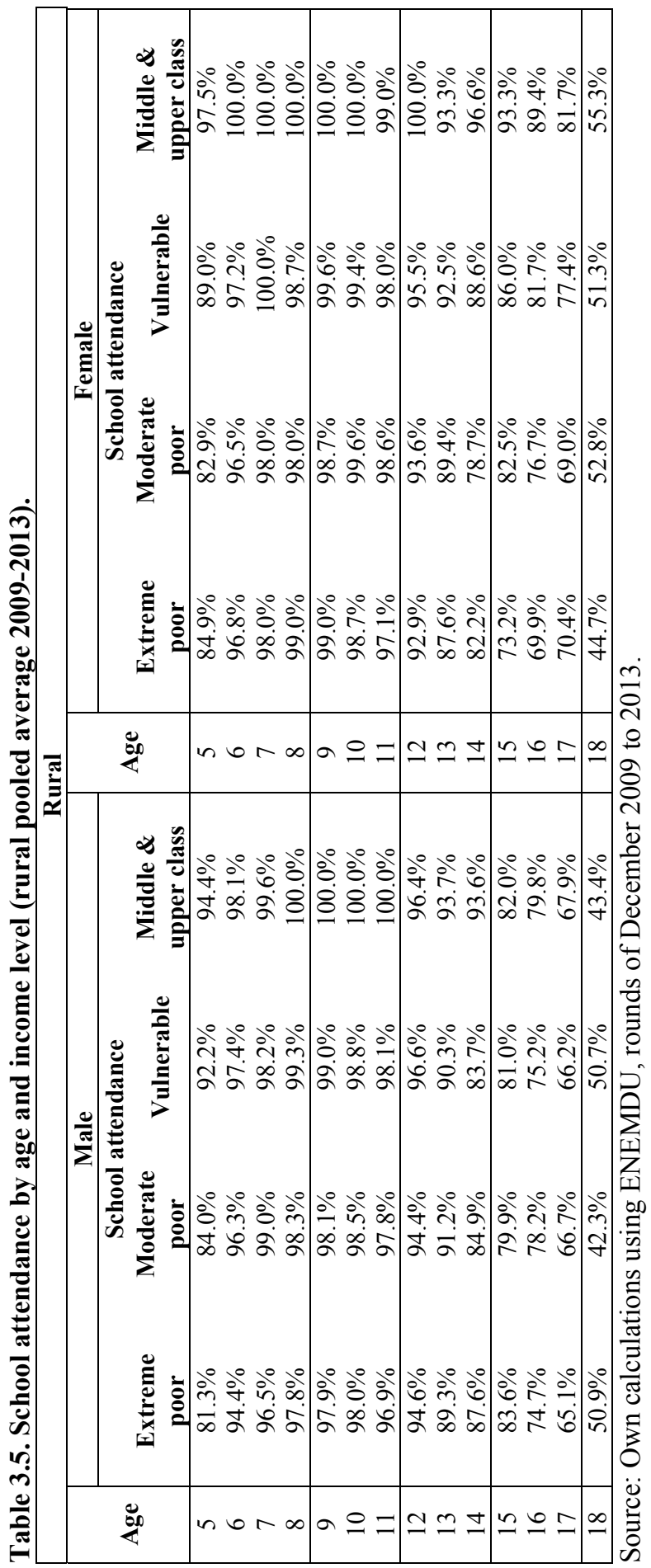


In addition, grade-specific and gender-specific promotion rates (Table 3.6) for primary and secondary education were estimated using administrative data from the Ecuadorian Ministry of Education. Finally, age-specific survival rates (Table 3.7) were estimated as the average between 2011 and 2020 from the official population projections of the National Institute of Statistics and Censuses (INEC)

Table 3.6. Grade-specific promotion rate.

\begin{tabular}{|c|c|c|}
\hline \multicolumn{3}{|c|}{ Promotion } \\
\hline Grade & Males & Females \\
\hline 1 & $99.27 \%$ & $99.18 \%$ \\
2 & $98.80 \%$ & $98.43 \%$ \\
3 & $99.10 \%$ & $98.88 \%$ \\
4 & $99.31 \%$ & $99.07 \%$ \\
\hline 5 & $99.41 \%$ & $99.26 \%$ \\
6 & $99.47 \%$ & $99.28 \%$ \\
7 & $99.57 \%$ & $99.42 \%$ \\
\hline 8 & $98.32 \%$ & $96.98 \%$ \\
9 & $98.46 \%$ & $97.53 \%$ \\
10 & $98.64 \%$ & $97.95 \%$ \\
\hline 11 & $97.37 \%$ & $95.92 \%$ \\
12 & $98.92 \%$ & $98.26 \%$ \\
13 & $99.69 \%$ & $99.46 \%$ \\
\hline
\end{tabular}

Source: I calculated these using the 2013's Master Archive of Educational Institutions (AMIE) of the Ecuadorian Ministry of Education.

Table 3.7. Age-specific survival rate.

\begin{tabular}{|c|c|c|c|}
\hline Age & Survival & Age & Survival \\
\hline 5 & $99,95 \%$ & 15 & $99,87 \%$ \\
\hline 6 & $99,96 \%$ & 16 & $99,84 \%$ \\
\hline 7 & $99,97 \%$ & 17 & $99,81 \%$ \\
\hline 8 & $99,97 \%$ & 18 & $99,79 \%$ \\
\hline 9 & $99,97 \%$ & 19 & $99,77 \%$ \\
\hline 10 & $99,96 \%$ & 20 & $99,76 \%$ \\
\hline 11 & $99,95 \%$ & 21 & $99,75 \%$ \\
\hline 12 & $99,94 \%$ & 22 & $99,74 \%$ \\
\hline 13 & $99,92 \%$ & 23 & $99,75 \%$ \\
\hline 14 & $99,90 \%$ & & \\
\hline
\end{tabular}

Source: I calculated these using the Population Projections of the Ecuadorian National Institute of Statistics and Censuses (INEC). 


\subsubsection{Evaluation strategy}

The causal effect of the BDH was calculated following Ponce and Bedi (2010), who relied on a regression discontinuity (RDD) model using instrumental variables (IV). This strategy identified the effect of those close to the targeting threshold to control for non-observable characteristics. However, it could not capture the effect on the very poor. The model was estimated using the 2009-2013 pooled data for children 5 - 18 years old using the RS index from 2009, which was $31.50-41.50$ (i.e., + /- 5 points around the RS threshold of 36.50). The RS index was estimated using administrative data from the Registro Social. The 2009's RS index used 30 variables, but only 26 variables could be replicated in the ENEMDU. Therefore, it was necessary not only to impute the RS index in the ENEMDU, but to rescale the index due to the lack of variables. First, this was done by estimating a partial index (RS $2009^{26}$ ) using the available variables and official weights of the RS index. Second, I estimated an equation to replicate the RS 2009 index using Registro Social's administrative data (Equation 5).

$R \widehat{S 2009}=-5.310639+\left(1.199731 * R S 2009^{26}\right)$

(Equation 5)

After the estimation of the RS index in the ENEMDU, the BDH's eligibility threshold of 36.50 was localized at the $41^{\text {st }}$ percentile in the ENEMDU 2009, which corresponded to the date of the Registro Social. However, the welfare conditions of households were likely to change over time. For this reason, the eligibility threshold was estimated for the years $2010-2013$ as the value at the $41^{\text {st }}$ percentile of the $R \widehat{S 2009}$.

Treatment discontinuity occurred in the RS index. The probability to be eligible to receive the $\mathrm{BDH}$ in 2009 was $25 \%$ for those households with a 
$R \widehat{S 2009}$ higher than 36.50 , but it was $75 \%$ if the $R \widehat{S 2009}$ was lower than the cut-off. If reduced to those $+/-5$ points around the threshold, these probabilities were $53 \%$ and $67 \%$, respectively (Fig. 3.1).

Figure 3.1. Relation between eligibility and RS index (2009).
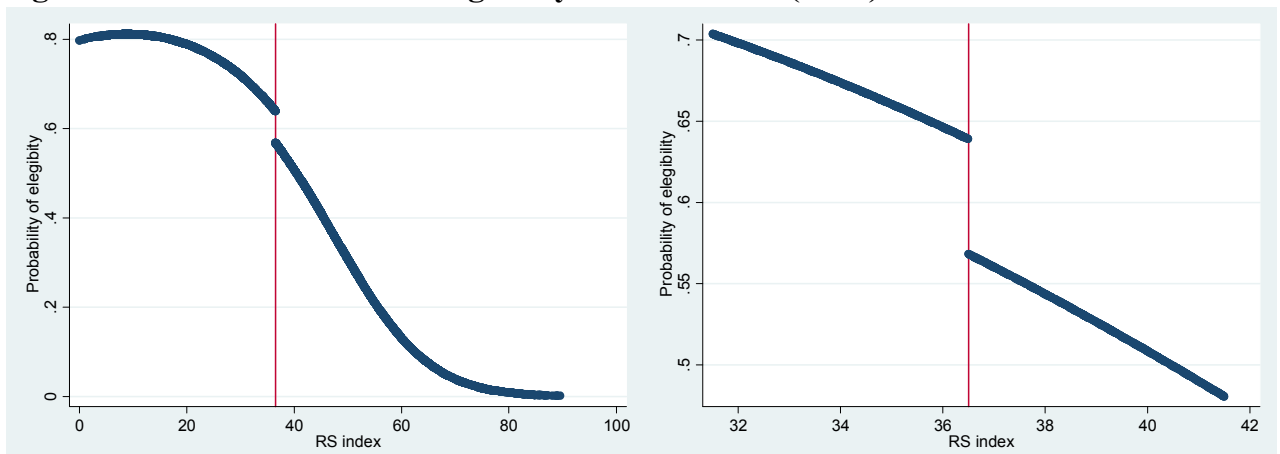

Source: I calculated the curves using ENEMDU, round of December 2009.

This non-linear relationship provided exogenous variation in treatment status. However, because it was unlikely that treatment was assigned solely by this criterion, I assumed there was a fuzzy discontinuity, and then the evaluation strategy included an IV approach. The first stage equation included an instrument $\left(T_{i}\right)$, the RS index $(R \widehat{S 2009})$, its square value $\left(R \widehat{S 2009^{2}}\right)$, and other variables $\left(\mathrm{X}_{\mathrm{i}}\right)$, which assumed an independent and identically distributed (i.d.d.) error term $(\varepsilon)$ with mean zero (Equation 6). The instrument was the assignment rule, and then it was correlated with BDH eligibility; we assumed that it was not correlated with the unobserved characteristics that determined the evaluated variables (i.e., school assistance and married status).

$b d h_{i}=\left(\zeta * T_{i}\right)+(\theta * R \widehat{S 2009})+\left(\vartheta * R \widehat{S 200} 9^{2}\right)+\left(\kappa * \mathrm{X}_{\mathrm{i}}\right)+\varepsilon_{i}$

(Equation 6) 
Following this strategy, the probability of school attendance and marriage was estimated by a two-stage probit model. The first stage was calculated by equation 6 , and the second stage estimate was obtained by:

$\operatorname{Pr}\left(\right.$ attendance $_{i}=\Phi\left(\tau * \widehat{b d h_{\imath}}+\gamma * b d h_{-} p c_{i}+\delta *\right.$ past $_{i}+\rho *$ married $_{i}+\eta * \mathrm{~K}_{i}+$ $\left.\psi_{i}\right)$

(Equation 7)

$\operatorname{Pr}(\text { married })_{i}=\Phi\left(\alpha * \widehat{b d h_{l}}+\beta *\right.$ schooling $\left._{i, t-1}+\theta * \mathrm{H}_{i}+\omega_{i}\right)$ (Equation 8)

where $\Phi$ was the cumulative distribution function of the standard normal distribution, $\mathrm{K}_{i}$ and $\mathrm{H}_{i}$ were vectors of observable characteristics and a constant, and $\psi_{i}$ and $\omega_{i}$ were independent and identically distributed (i.d.d.) error terms with mean zero, respectively.

Household income had a negligible effect on the probability of school attendance. Although it was statistically significant in the expected direction (positive effect), the coefficient was low. However, the cost of opportunity had a negative and significant effect. That is, a higher opportunity cost in terms of forgone income reduced the probability of attending school at any age. On average, females had a lower probability of attending school in comparison with males. The coefficients of interest for the model showed that school delay and being married reduced the probability of attending school. In the case of the $\mathrm{BDH}$, there was a negative coefficient that reduced the constant term for those who received the transfers, and the amount received increased the probability of attending school. The BDH did not necessarily increase school attendance, because it was not strongly conditioned. Also, school attendance is almost universal in Ecuador, and the size of the transfer was sufficient to cover the opportunity costs for those who did not attend school. Each 1 USD per month per capita of transfer increased the probability 
of attending school by 5.17 percentage points (p.p.). Each year of school delay reduced the probability of attending school by 3.03 p.p., and being married reduced it by 9.51 p.p. (Table 3.8).

Child marriage was a crucial determinant of school attendance. The probability of marriage incresed with age, being female, household size, and poverty conditions, for example, lack of access to water and sanitation. On the other hand, schooling reduced the probability of marriage and receiving $\mathrm{BDH}$. Average marginal effects showed that a person living in a $\mathrm{BDH}$ recipient household had a 1.92 p.p. lower probability of getting married. An additional year of education reduced the probability of marriage by 2.17 p.p. (Table 3.8). BDH may have encouraged school attendance directly based on its amount, but also because of its effect on the reduction in child marriage. 
Table 3.8. Two-stage probit model and average marginal effects on school attendance and marriage status (ENEMDU 2009-2013).

\begin{tabular}{|c|c|c|c|c|c|}
\hline \multirow{3}{*}{$\begin{array}{l}\text { IV probit (RDD, }+/-\mathbf{5}) \\
\text { Receiving the } \mathrm{BDH}(\mathrm{Yes}=1 / \mathrm{No}=0) \\
\text { BDH amount per month per capita }\end{array}$} & \multicolumn{2}{|c|}{$\begin{array}{c}\text { School } \\
\text { attendance }\end{array}$} & IV probit (RDD, +/- 5) & \multicolumn{2}{|c|}{ Married } \\
\hline & $\begin{array}{r}-2.8775 \\
(0.0202)\end{array}$ & $* * *$ & Receiving the $\mathrm{BDH}(\mathrm{Yes}=1 / \mathrm{No}=0)$ & $\begin{array}{r}-0.1792 \\
(0.0311) \\
\end{array}$ & $* * *$ \\
\hline & $\begin{array}{r}0.2966 \\
(0.0023) \\
\end{array}$ & $* * *$ & $\begin{array}{l}\text { Expected paidlabour income per } \\
\text { month per capita }\end{array}$ & $\begin{array}{r}0.0014 \\
(0.0002)\end{array}$ & $* * *$ \\
\hline $\begin{array}{l}\text { Expected paidlabour income per } \\
\text { month per capita }\end{array}$ & $\begin{array}{r}-0.0527 \\
(0.0004)\end{array}$ & *** & $\begin{array}{l}\text { Household income per month per } \\
\text { capita }\end{array}$ & $\begin{array}{r}0.0000 \\
(0.0000)\end{array}$ & \\
\hline $\begin{array}{l}\text { Household income per month per } \\
\text { capita }\end{array}$ & $\begin{array}{r}0.0001 \\
(0.0000) \\
\end{array}$ & $* * *$ & 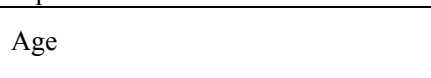 & $\begin{array}{r}0.7775 \\
(0.0083)\end{array}$ & $* * *$ \\
\hline 1 & $\begin{array}{r}0.3745 \\
(0.0037)\end{array}$ & *** & Age squared & $\begin{array}{r}-0.0167 \\
(0.0002)\end{array}$ & $* * *$ \\
\hline Age squared & $\begin{array}{r}-0.0148 \\
(0.0002)\end{array}$ & $* * *$ & Female $(\mathrm{Yes}=1 / \mathrm{No}=0)$ & $\begin{array}{r}0.0292 \\
(0.0037)\end{array}$ & $* * *$ \\
\hline Past (= age -5 - schooling) & $\begin{array}{r}-0.1739 \\
(0.0020)\end{array}$ & $* * *$ & Schooling & $\begin{array}{r}-0.0217 \\
(0.0008) \\
\end{array}$ & $* * *$ \\
\hline Female $(\mathrm{Yes}=1 / \mathrm{No}=0)$ & $\begin{array}{r}-0.0294 \\
(0.0029)\end{array}$ & $* * *$ & Household's dependency ratio & $\begin{array}{r}-0.0582 \\
(0.0031)\end{array}$ & $* * *$ \\
\hline Married $(\mathrm{Yes}=1 / \mathrm{No}=0)$ & $\begin{array}{r}-0.5459 \\
(0.0092)\end{array}$ & $* * *$ & Households size & $\begin{array}{r}0.1090 \\
(0.0012)\end{array}$ & $* * *$ \\
\hline $\begin{array}{l}\text { Indigenous/montubio/afro (Yes }=1 / \\
\mathrm{No}=0 \text { ) }\end{array}$ & $\begin{array}{r}0.0749 \\
(0.0029)\end{array}$ & $* * *$ & Water and sanitation $(\mathrm{Yes}=0 / \mathrm{No}=1)$ & $\begin{array}{r}0.1453 \\
(0.0041)\end{array}$ & $* * *$ \\
\hline Rural $(\mathrm{Yes}=1 / \mathrm{No}=0)$ & $\begin{array}{r}0.0534 \\
(0.0023)\end{array}$ & $* * *$ & Rural $(\mathrm{Yes}=1 / \mathrm{No}=0)$ & $\begin{array}{r}-0.1733 \\
(0.0056)\end{array}$ & $* * *$ \\
\hline $2010(\mathrm{Yes}=1 / \mathrm{No}=0)$ & $\begin{array}{r}0.4929 \\
(0.0045)\end{array}$ & $* * *$ & Parish's poverty head count & $\begin{array}{r}-0.0184 \\
(0.0147) \\
\end{array}$ & \\
\hline $2011(\mathrm{Yes}=1 / \mathrm{No}=0)$ & $\begin{array}{r}0.6992 \\
(0.0055)\end{array}$ & $* * *$ & $2010(\mathrm{Yes}=1 / \mathrm{No}=0)$ & $\begin{array}{r}0.0829 \\
(0.0056)\end{array}$ & $* * *$ \\
\hline $2012(\mathrm{Yes}=1 / \mathrm{No}=0)$ & $\begin{array}{r}0.5436 \\
(0.0057)\end{array}$ & $* * *$ & $2011(\mathrm{Yes}=1 / \mathrm{No}=0)$ & $\begin{array}{r}0.0472 \\
(0.0062)\end{array}$ & $* * *$ \\
\hline $2013(\mathrm{Yes}=1 / \mathrm{No}=0)$ & $\begin{array}{r}0.0629 \\
(0.0035)\end{array}$ & $* * *$ & $\begin{array}{l}2012(\mathrm{Yes}=1 / \mathrm{No}=0) \\
2013(\mathrm{Yes}=1 / \mathrm{No}=0)\end{array}$ & $\begin{array}{r}-0.0144 \\
(0.0063) \\
0.0790 \\
(0.0060) \\
\end{array}$ & $* * *$ \\
\hline Constant & $\begin{array}{r}0.1685 \\
(0.0134) \\
\end{array}$ & $* * *$ & Constant & $\begin{array}{r}-10.5098 \\
(0.0732) \\
\end{array}$ & $* * *$ \\
\hline Observations & $2,346,55$ & & Observations & $1,864,1$ & \\
\hline $\begin{array}{l}\text { Average marginal eff } \\
\text { at }(\mathrm{BDH} \text { amount per month per } \\
(\text { Past }=0)\end{array}$ & pita $=0)$ a & & $\begin{array}{c}\text { Average marginal effe } \\
\text { at (Schooling }=0)\end{array}$ & & \\
\hline BDH amount per month per capita & $\begin{array}{r}0.0517 \\
(0.0003)\end{array}$ & *** & Receiving the $\mathrm{BDH}(\mathrm{Yes}=1 / \mathrm{No}=0)$ & $\begin{array}{r}-0.0192 \\
(0.0035)\end{array}$ & $* * *$ \\
\hline Past (= age -5 - schooling) & $\begin{array}{l}-0.0303 \\
(0.0008)\end{array}$ & $* * *$ & Schooling & $\begin{array}{r}-0.0023 \\
(0.0001)\end{array}$ & $* * *$ \\
\hline Married $(\mathrm{Yes}=1 / \mathrm{No}=0)$ & $\begin{array}{r}-0.0951 \\
(0.0025)\end{array}$ & $* * *$ & & & \\
\hline
\end{tabular}

Note: Heteroskedasticity consistent standard errors are between brackets. Estimates used pooled data from 2009 - 2013. School attendance was estimated for children 5 - 18 years old, and it was estimated for those who were married $12-23$ years old.

$* * *$ Significance at $1 \%$, ** significance at $5 \%, *$ significance at $10 \%$

Source: Own calculations using ENEMDU, rounds of December 2009 to 2013. 


\subsection{Results}

The model simulated a cohort of 1,056 children (197,892 using weights) starting at 5 years old, of which $52.3 \%$ were girls and $40.9 \%$ were receiving the BDH. Data were from ENEMDU, round of December 2013. In the base line model (Scenario 1 - no social transfer), the cohort achieved 12 years of education (schooling) at the age of 18, which is equivalent to incomplete secondary education (Table 9). ${ }^{30}$

To analysis the cost-effectiveness of a social transfer on accumulation of human capital, three additional scenarios wee simulated. Scenario 2 simulated the BDH in its actual design. This scenario included a flat transfer of 50 USD to each eligible household that was identified in ENEMDU 2013 up to age of 18. Scenario 3 simulated a variable transfer to households with extreme income poverty. The transfer was defined based on the specific household's poverty gap (up to 37.64 USD per month at prices of 2009). It aimed to test a perfect targeting design on the poorest. Finally, scenario 4 transferred an amount equal to the poverty line (66.78 USD per month at prices of 2009) to poor individuals 12 - 18 years old, which are critical periods for school attendance. It tested targeting at critical ages.

All scenarios achieved lower rates of marriage (Equation 1), higher school attendance (Equation 2), and and more schooling (Equation 3) at any age in comparison with the scenario with-out a social transfer, but the cohort population declined equally for all scenarios (Equation 4). Scenario 2 evaluated the $\mathrm{BDH}$ in its actual design. At 18 years old, it reduced the percentage of child marriage from $1.5 \%$ to $0.9 \%$. School attendance increased by 4.2 p.p. at 5 years old, by 0.6-1.1 p.p. at 6 - 11 years old, and by 2.1-18.4

\footnotetext{
${ }^{30}$ My estimates using pooled data from ENEMDU showed that, on average, between 2009 and 2013 a cohort at the age of 18 years old achieved 10.31 years of education. 78
} 
p.p. at 12 - 18 years old. These results promoted higher human accumulation of 0.4 additional years of education per person at the age of 18 . This summed to 88,551 additional years of education for the total cohort's human capital. Scenarios 3 and 4 had lower effects on child marriage, school attendance, and schooling, as expected (Table 3.9). In general, social transfers had a positive effect on accumulation of human capital, but the effects were low in Ecuador.

The cost of the transfer was 48.1-48.5 million USD per year in the case of scenario 2, which was approximately $0.05 \%$ of Ecuadorian GDP in $2013 .{ }^{31}$ The annual cost of scenarios 3 and 4 was 32.7-33.1 million USD (0.03 of GDP), and 57.2-57.6 million USD (0.06\% of GDP), respectively (Table 3.10).

To compare scenarios in terms of their cost-effectiveness, total cost was calculated by adding-up the annual cost of each policy option; total accumulation of human capital for the cohort was measured by adding-up the years of education that was achieved for each person within the cohort. A cost-effectiveness indicator was then estimated as the relationship between the additional cohort's total schooling in comparison with scenario 1 and the cost in million USD. In this sense, the indicator measured how many additional years of education was achieved by a cohort for each million USD that was invested in social transfers.

${ }^{31}$ World Bank (2017) 


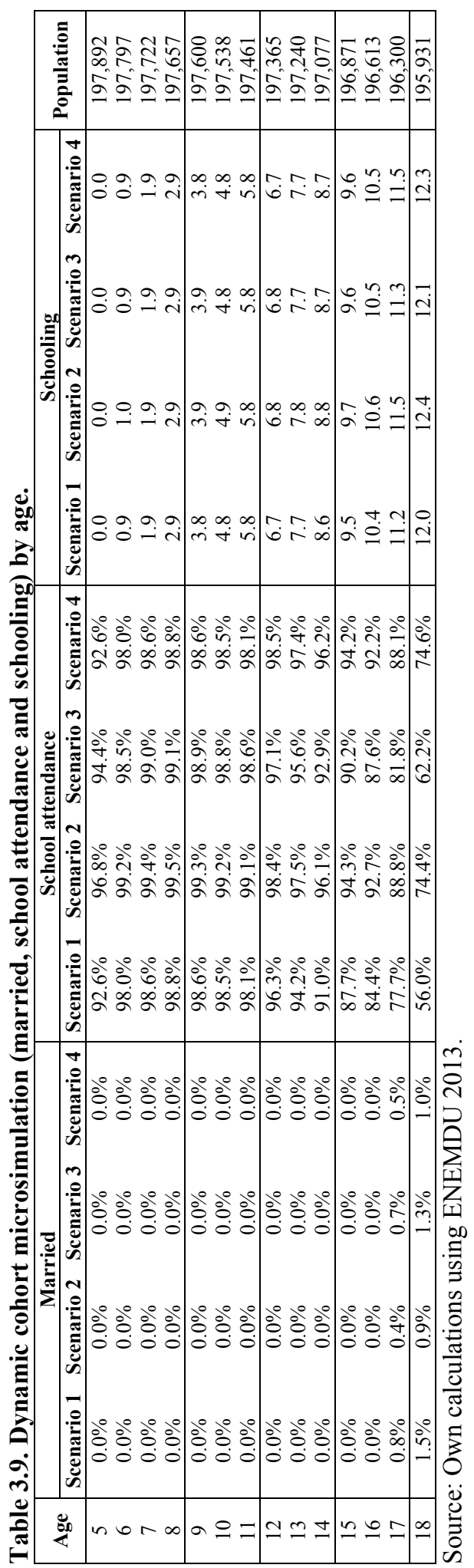




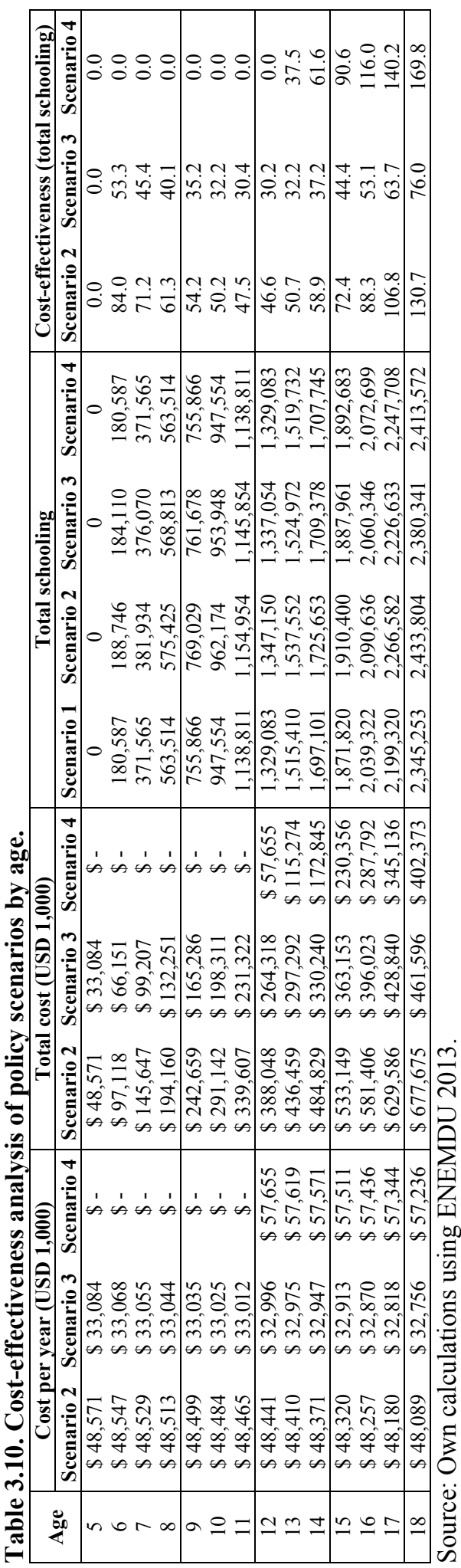


At the age of 18, the cost-effectiveness ratio had a value of 130.7 for scenario 2, 76.0 for scenario 3, and 169.8 for scenario 4 (Table 3.10). The latter was the most cost-effective. To promote accumulation of human capital, the best option was to target critical ages. However, it is also important to evaluate the effects on inequality. This was done by looking at average schooling that was achieved for different income brackets and its ratio with mean schooling. In the case where no social transfer was implemented, the average years of schooling for extreme poor individuals was 11.3 at the age of 18 , and it was 12.5 for middle-\&-upper class persons. In this sense, it generated a vicious circle of poverty and inequality. All policy scenarios reduced the gap, but the most efficient was scenario 3 where social transfers were designed to eradicate extreme income poverty and then promoted school attendance for the poorest of the poor (Table 3.11).

Table 3.11. Schooling inequality by income bracket.

\begin{tabular}{|l|cccc|}
\hline \multirow{2}{*}{ Income bracket } & \multicolumn{4}{|c|}{ Schooling } \\
\cline { 2 - 5 } & Scenario 1 & Scenario 2 & Scenario 3 & Scenario 4 \\
\hline Extreme poor & 11.3 & 12.3 & 12.8 & 12.5 \\
Moderate poor & 11.7 & 12.5 & 11.7 & 12.6 \\
Vulnerable & 12.0 & 12.4 & 12.0 & 12.0 \\
Middle \& upper class & 12.5 & 12.5 & 12.5 & 12.5 \\
\hline Total & 12.0 & 12.4 & 12.1 \\
\hline \multirow{2}{*}{ Income bracket } & \multicolumn{4}{|c|}{ Schooling / mean schooling } \\
\cline { 2 - 5 } & Scenario 1 & Scenario 2 & Scenario 3 & Scenario 4 \\
\hline Extreme poor & 0.95 & 0.99 & 1.05 & 1.01 \\
Moderate poor & 0.98 & 1.00 & 0.96 & 1.02 \\
Vulnerable & 1.01 & 1.00 & 0.99 & 0.98 \\
Middle \& upper class & 1.04 & 1.01 & 1.03 & 1.01 \\
\hline Total & 1.00 & 1.00 & 1.00 & 1.00 \\
\hline
\end{tabular}

Source: Own calculations using ENEMDU 2013.

\subsection{Final remarks}

Social transfers are being implemented in developing countries as a successful mechanism to reduce income poverty and inequality, and to promote human development objectives. They have the potential to generate 
economic returns at different levels. Social transfers affect poor households' disposable income and the way households allocate resources. Higher and reliable income helps households to invest in human capital by covering transaction and opportunity costs, and higher income aids the society to achieve social objectives and economic inclusion.

In this paper, a dynamic cohort microsimulation model was developed to explore accumulation of human capital during the lifetime of a cohort by following a cohort from the age of 5 to 18 (as discrete periods) using data from the Ecuadorian cash transfer programme called Bono de Desarrollo Humano $(\mathrm{BDH})$. Effects of the BDH were estimated for school attendance and marriage status. The model accounted for direct and indirect effects of social transfers on school attendance.

Results showed that social transfers promoted higher levels of schooling. At the age of 18 , the average level of schooling was $0.2-0.5$ years higher under social transfer scenarios. The effect (i.e., the difference with no social transfer) was higher under actual design of the BDH. However, social transfers were more cost-efficient to promote accumulation of human capital if they were targeted at critical ages, and they were more efficient in reducing schooling inequality if they were targeted at the poorest of the poor. Social transfers have the potential to promote accumulation of human capital and, thus, increase long-term economic returns. However, the effect depends on the existence of supply side policies to guarantee coverage and quality of educational services. 


\subsection{References}

Agüero, J., Carter, M., \& Woolard, I. (2007). The Impact of Unconditional Cash Transfers on Nutrition: The South African Child Support Grant. International Poverty Centre Working Paper 39.

Akresh, R., de Walque, D., \& Kazianga, H. (2013). Cash transfers and child schooling: evidence from a randomized evaluation of the role of conditionality. Washington D.C.: World Bank Policy Research Working Paper Series 6340.

Alderman, H., \& Yemtsov, R. (2012). Productive role of safety nets. Washington D.C.: The World Bank.

Arnold, C., Conway, T., \& Greenslade, M. (2011). Cash Transfers. Evidence Paper. London: Department for International Development.

Baird, S., Chirwa, E., Mcintosh, C., \& Olzer, B. (2010). The short term impacts of a schooling conditional cash transfer program on the sexual behaviour of young women. Health Economics, 19, 55-68.

Baird, S., Mcintosh, B., \& Olzer, B. (2011). Cash or condition? Evidence from a cash transfer experiment. The Quartely Journal of Economics, 126, 1709-1753. doi:10.1093/qje/qjr032

Baldini, M. (2001). Inequality and Redistribution over the Life-Cycle in Italy: an Analysis with a Dynamic Cohort Microsimulation Model. University of Modena and Reggio Emilia.

Barrera-Osorio, F., Bertrand, M., Linden, L., \& Perez-Calle, F. (2008). Consitional cash transfers in education design features, peer and sibling effect evidence from a randomized experiment in Colombia. Cambridge: NBER Working Paper 13890.

Barrientos, A. (2005). Non-contributory Pensions and Poverty Reduction in Brazil and South Africa. IDPM, University of Manchester. 
Barrientos, A. (2012). Social transfers and growth: What do we know? What do we need to find out? World Development, 40(1), 11-20.

Barrientos, A., \& Nino-Zarazua, M. (2010). Effects of non-contributory social transfers in developing countries: A compendium. Geneva: International Labour Organization.

Barrientos, A., \& Sabates-Wheeler, R. (2009). Do transfers generate local economy effects? Manchester: BPWI Working Paper 106.

Barrientos, A., \& Scott, J. (2008). Social transfers and growth: A review. BWPI Working Paper.

Barrientos, A., Niño-Zarazúa, M., \& Maitrot, M. (July de 2010). Social Assistance in Developing Countries Database. (T. U. Brooks Poverty Institute, Ed.)

Obtenido de http://www.chronicpoverty.org/publications/details/socialassistance-in-developing-countries-database

Bastagli, F., Hagen-Zanker, J., Harman, L., Barca, V., Sturge, G., Schmidt, T., \& Pellerano, L. (2016). Cash transfers: what does the evidence say? London: Overseas Development Institute.

Becker, G. (1975). Human capital. A theoretical and empirical abnalysis with specific references to education (Second ed.). Chicago: The University of Chicago Press.

Becker, G., \& Tomes, N. (1986). Human Capital and the Rise and Fall of Families. Journal of Labor Economics, 4(2), S1-S39.

Becker, G., \& Tomes, N. (1994). Human Capital and the Rise and Fall of Families. In G. Becker, Human Capital: A Theoretical and Empirical Analysis with Special Reference to Education (pp. 257-298). The University of Chicago. 
Benhassine, N., Devoto, N., Duflo, E., Dupas, P., \& Pouliquen, V. (2013). Turning a shove into a nudge? Cambridge: NBER Workig Paper 19227.

Cherrier, C., Gassmann, F., Mideros, A., \& Mohnen, P. (2013). Making the investment case for social protection. Methodological challenges with lessons learnt from a recent study in Cambodia. Florence: UNICEF Office of Research Working Paper 2013-06.

Fernald, L., Gertler, P., \& Neufeld, L. (2008). Role of cash in conditional cash transfer programmes for child health, growth, and development: an analysis of Mexico's Oportunidades. The Lancet, 374(9615), 828837.

Fernald, L., Gertler, P., \& Neufeld, L. (2009). 10-year effect of Oportunidades, Mexico's conditional cash transfer programme, on child growth, cognition, language, and behaviour: a longitudinal follow-up study,. The Lancet, 374(9706), 1997-2005.

Geyer, J., \& Steiner, V. (2010). Public Pensions, Changing Employment Patterns, and the Impact of Pension Reforms across Birth Cohorts: A Microsimulation Analysis for Germany. IZA Discussion Paper No. 4815.

Gilligan, D., Margolies, A., Quinones, E., \& Roy, S. (2013). Impact Evaluation of Cash and Food Transfers at Early Childhood Development centres in Karamoja, Uganda. Final impact report. Washington D.C.: IFPRI.

Hartog, J., \& Oosterbeek, H. (2007). What should you know about the private returns to education? In J. Hartog, \& H. M. van den Brink, Human capital. Advances in theory and evidence (pp. 7-20). Cambridge: Cambridge University Press. 
Heckman, J. (1976). A life-cycle model of earnings, learning an consumption. Journal of Political Economy, 84(4), S11-S44.

Heckman, J., \& Mosso, S. (2014). The economics of human development and social mobility. Bonn: IZA Discussion Paper 8000.

IEG. (2011). Evidence and Lessons Learned from Impact Evaluations on Social Safety NEts. Washington DC: Independent Evaluation Group, IEG. World Bank, IFC, MIGA.

Jacobs, B. (2007). Optimal tax and education policies and investments in human capital. En J. Hartog, \& H. M. van den Brink, Human capital. Advances in theory and evidence (págs. 212-232). Cambridge: Cambridge University Press.

Li, J., \& O'Donoghue, C. (2013). A survey of dynamic microsimulation models: uses, model structure and methodology. International Journal of Microsimulation, 6(2), 3-55.

Lindahl, M., \& Canton, E. (2007). The social returns to education. En J. Hartog, \& H. M. van den Brink, Human capital. Advances in theory and evidence (págs. 21-37). Cambridge: Cambridge University Press.

Lopez-Calva, L., \& Ortiz-Juarez, E. (2011). A Vulnerability Approach to the Definition of the Middle Class. Washington D.C.: Policy Research Working Paper 5902.

Lucas Jr., R. (1988). On the mechanics of economic development. Journal of Monetary Economics, 2, 3-42.

Macours, K., Schady, N., \& Vakis, R. (2012). Cash Transfers, Behavioural Changes, and Cognitive Development in Early Childhood: Evidence from a Randomized Experiment. American Economic Journal: Applied Economics, 4(2), 247-273. 
Merz, J. (1993). Microsimulation as an Instrument to Evaluate Economic and Social Programmes. Forschungsinstitut Freie Berufe Discussion Paper No. 5.

Mideros, A., Gassmann, F., \& Mohnen, P. (2012). Estimation of rates of return of social protection instruments in Cambodia. A case for noncontributory social transfers. Maastricht: Maastricht Graduate School of Governance (MGSoG).

Mideros, A., Gassmann, F., \& Mohnen, P. (2016). Estimation of rates of return on social protection: ex ante microsimulation of social transfers in Cambodia. Journal of Development Effectiveness, 8(1), 67-86.

Mincer, J. (1974). Schooling, experience and earnings. New York: National Bureau for Economic Research. Columbia University Press.

Notten, G., \& Gassmann, F. (2008). Size Matters: Targeting Efficiency and Poverty Reduction Effects of Means-tested and Universal Child Benefits in Rusia. Journal of European Social Policy, 18(3), 260-274. Paxson, C., \& Schady, N. (2010). Does Money Matter? The Effects of Cash Transfers on Child Development in Rural Ecuador. Economic Development and Cultural Change, 59(1), 187-229.

Plug, E. (2007). Are successful parents the secret to success? En J. Hartog, \& H. M. van den Brink, Human capital. Advances intheory and evidence (págs. 81-100). Cambridge: Cambridge University Press.

Ponce, J., \& Bedi, A. (2010). The impact of a cash transfer program on cognitive achievement: The Bono de Desarrollo Humano of Ecuador. Economics of Education Review, 116-125.

Romer, P. (1990). Endogenous technological change. Journal of Political Economy, 98(5), S71-S102. 
Rosen, S. (1976). A theory of life earnings. Journal of Political Economy, 84(4), S45-S67.

Sadoulet, E., De Janvry, A., \& Davis, B. (2001). Cash Transfer Programs with Income Multipliers: PROCAMPO in Mexico. World Development, 29(6), 1043-1056.

Samson, M., Lee, U., Ndlbe, A., Mac Quene, K., van Niekerk, I., GHarigaya, T., \& Abrahams, C. (2004). The Social and Economic Impact of South Africa's Social Security System. Economic Policy Reseacrh Institute, EPRI.

Schady, N., \& Araujo, M. C. (2008). Cash transfers, conditions, and school enrolment in Ecuador. Economía, 8(2), 43-77.

Schady, N., \& Rosero, J. (2008). Are Cash Transfers Made to Women Spent like Other Sources of Income? Economic Letters(101), 246-248.

Sen, A. (1997). Editorial: Human Capital and Human Capability. World Development, 25(12), 1959-1961.

Szirmai, A. (2012). Proximate, intermediate and ultimate causality: Theories and experiences of growth and development. Maastricht: UNUMERIT Working Paper Series 2012-032.

Thome, K., Filipski, M., Kagin, J., Taylor, J., \& Davis, B. (2013). Agricultural Spillover Effects of Cash Transfer: What Does LEWIE Have to Say? Amer. J. Agr. Econ., 95(5), 1338-1344.

Tirivayi, N., Knowles, M., \& Davis, B. (2013). The interaction between social protection and agriculture. Rome: Food and Agriculture Organization (FAO).

UNICEF. (2012). Integrated Social Protection Systems. Enhancing Equity for Children. New York: United Nations Children's Fund. 
van de Ven, J. (2006). Simulating Cohort Earnings for Australia. En J. Creedy, \& G. Kalb, Dynamics of Inequality and Poverty (Research on Economic Inequality, Volume 13) (págs. 63-80). Oxford: Emerald Group Publishing Limited.

van der Sluis, J., \& van Praag, M. (2007). Human capital and entrepreneurs. En J. Hartog, \& H. M. van den Brink, Human capital. Advances in theory and evidence (págs. 52-64). Cambridge: Cambridge University Press.

Villa, J. M. (2014). The lenght of exposure to antipoverty transfer programmes: what is the relevance for children's human capital foramtion? Manchester: BWPI Working Paper 206.

World Bank. (2015). The State of Social Safety Nets. Washington D.C.: The World Bank.

World Bank. (27 de 03 de 2017). World Bank. Obtenido de http://data.worldbank.org/indicator/NY.GDP.MKTP.CN?locations=EC 


\section{Chapter 4 - Social mobility ${ }^{32}$}

\subsection{Introduction}

Social protection programmes are implemented in many low and middleincome countries due to their efficacy in reducing poverty, vulnerability, and inequality. Over the last decade, evidence on the positive effects of investments in social protection has accumulated. ${ }^{33}$ Social transfers have proved to impact positively the development of human capital, labour supply, and accumulation of assets. They strengthen social networks and stimulate local markets. However, the literature is scarce regarding long-term effects of social transfers, such as the effects on social mobility of the poor and the reduction of chronic poverty. ${ }^{34}$ It is relevant to analyse how sustainable the effects of social transfers are. Moreover, social mobility as a notion of origin independence is desirable, because it is a necessary condition to guarantee that a person has the freedom to achieve whatever she wants to achieve in the future.

The accumulation of human and physical capital and the reduction of fertility rates, which leads to smaller households, might be key for a sustainable exit from chronic poverty and to reduce the likelihood that the next generation is poor (Jalan \& Ravallion, 2000). The command over human,

\footnotetext{
32 This paper has been published as: Mideros A. \& Gassmann, F. (2017). Fostering Social Mobility: The case of the Bono de Desarrollo Humano in Ecuador. UNU-MERIT Working Paper Series 2017-002.

${ }^{33}$ For surveys of empirical evidence, see Handa \& Davis (2006), Barrientos \& Scott (2008), Barrientos \& Niño-Zarazúa (2010), Arnold et al (2011), IEG (2011), Barrientos (2012), UNICEF (2012), Alderman \& Yemtsov (2012), Mideros et al. (2012), Tirivayi et al. (2013), World Bank (2015), and Bastagli et al. (2016).

${ }^{34}$ For a discussion on chronic poverty, see Jalan \& Ravallion (2000), Hulme et al. (2001), and Hulme \& Shepherd (2003). For a link between upward social mobility and overcoming chronic poverty, see Carter \& Barrett (2006).
} 
financial, and physical capital increases the resilience of households to withstand shocks. If households invest part of the social transfer in the accumulation of human and physical capital, this could eventually change their welfare trajectory and reduce the likelihood that they become poor in the event of a shock. McCulloch \& Baulch (2000) have shown that interventions that enabled households to smooth income over time reduced transitory poverty significantly.

The main question this paper aims to answer is whether and to what extent social transfers foster social mobility of poor households. Social mobility is generally understood as a long-term process by which households change their position in the welfare distribution (Baulch \& Hoddinott, 2000). In this paper, we contribute by looking at social mobility not as a change in the income distribution (often called economic mobility), educational level, or occupational status (often called social mobility), as is generally done in the literature (see, for example, Baulch \& Hoddinott (2000), Woolard \& Klasen (2005), Azevedo \& Bouillon (2009), Crawford et al. (2011), Sandberg (2012), Rodriguez-Oreggia \& Freije (2012), Jäntti \& Jenkins (2015), Lambert et al. (2014), and Cano (2015)), but by considering a multidimensional welfare indicator that reflects the importance of different dimensions of structural poverty conditions (Carter \& Barrett, 2006) and human development. Furthermore, by looking at intra-generational upward mobility, we first analysed the extent to which households changed their position in the welfare distribution over time, and we examined the determinants that explained such movements. Subsequently, we looked at the role social transfers played in this process. The latter is relevant to evaluate the effect of social transfers beyond their transitory consumption smoothing and poverty reduction effect; this is something that is scarcely done in the literature. The 
analysis considered human development trajectories at the household level, both in absolute and relative terms. For absolute mobility, we analyzed the effect on welfare growth, and for relative mobility we focused on the probability of a change in positive rank.

Additionally, we contributed empirical evidence by evaluating the Ecuadorian Bono de Desarrollo Humano (BDH) using administrative panel data from the Ecuadorian Registro Social (RS). The data contained information on beneficiary and non-beneficiary households at three points in time (2002-2003, 2008-2009, and 2013-2014), which allowed the creation of a panel and the evaluation of the effect of the BDH over a decade. The panel followed 413,043 households over the three periods. We used the RS index as the welfare indicator, which is a composite human development indicator that was estimated by principal components, and this provided a value between 0 and 100 for each household. It is used in Ecuador to target the BDH and other social programmes.

We assessed social mobility in three ways. First, we considered the poverty transition matrix. Secondly, we identified the determinants of social mobility both in absolute (welfare growth) and relative (changes in rank) terms. Finally, we estimated the effect of the BDH on absolute mobility. Moreover, we calculated the effect of the transfer amount among beneficiaries and the effect of an alternative programme called Crédito de Desarrollo Humano (CDH), which pays a yearly amount aimed at promoting productive investments, instead of a monthly transfer for consumption.

The rest of the paper is organized as follows. Section two discusses the theoretical framework to analyse the effect of social transfers on social mobility. Section three introduces the data and methodology. Results are presented in section four, and section five includes our conclusions. 


\subsection{Theory and evidence}

Social mobility is a long-term process by which households change their relative position in the welfare distribution (Baulch \& Hoddinott, 2000). Jäntti \& Jenkins (2015) distinguished four different concepts of social mobility. First, mobility as positional change looks at variations in population rank. If the change in position does not affect the concentration of people in a particular slot, it concerns exchange mobility; otherwise, it reflects structural mobility. In the first case, mobility of one person depends on other people's situation, and the transition matrix accounts for the probability of moving from one position to another. It is essentially a concept of relative mobility. Second, absolute mobility as individual growth focuses on individual changes over time, and mobility is defined as the distance between the initial and final situation. Third, mobility as reduction of longer-term inequality is characterized in terms of the extent to which longer-term welfare (i.e., average welfare) inequality is lower than in the case of period-specific income distributions. Finally, mobility as risk gives a behavioural interpretation to the longer-term welfare average (i.e., expected future welfare). The reduction in inequality is interpreted as a measure of risk. In this perspective, the longterm average is a permanent component, and the period-specific deviation (i.e., transitory component) represents unexpected idiosyncratic shocks. Higher dispersion of the transitory component across individuals denotes higher risk.

In addition, social mobility can be considered within- or betweengenerations. The first concentrates on changes between two points of time over the life cycle of a person (i.e., intra-generational mobility), and the latter examines changes between generations of parents and children (i.e., 
intergenerational mobility) (Jäntti \& Jenkins, Income mobility, 2015). In this paper, we analysed intra-generational mobility at the household level in Ecuador, following the concepts of relative and absolute social mobility.

Social mobility is desirablem because it reflects greater equality of opportunities. It means that where a person ends up is not (or is less) conditioned on where she started from (Jäntti \& Jenkins, Income mobility, 2015). This concept of origin independence indicates the degree to which future well-being is independent of present well-being (Gottschalk \& Spolaore, 2002). We relate this concept with the human development approach in the sense that origin independence is a necessary condition to guarantee that a person can achieve whatever she wants in the future (i.e., freedom of choice) without it being pre-conditioned by her current situation. ${ }^{35}$

\subsubsection{Social mobility and poverty dynamics: the role of social transfers}

Azevedo and Bouillon (2009) related social mobility to the idea of guaranteeing equal economic opportunities for all. Hence, the lack of mobility was associated with the generation of inequality, poverty, and social exclusion. In this sense, upward social mobility indicates a process of escaping chronic poverty. Using the concept of social mobility allows the analysis of the temporal dimension, and the reasons why some households do (not) increase their well-being over time. It is important to distinguish between transitory and chronic poverty. From the perspective of an antipoverty policy, transitory poverty demands strategies to smooth household consumption, but chronic poverty needs interventions to foster welfare

\footnotetext{
${ }^{35}$ The human development paradigm provides a people's centered focus of development, based on the capability approach (Robeyns, 2005). From this perspective, development is about expanding capabilities, choices, and agency of all people (Funkada-Parr, 2003). In this sense, human development is multidimensional (Alkire, 2002).
} 
growth (McCulloch \& Baulch, 2000). Given that chronic or permanent poverty is associated with low endowments and returns, intra-generational social mobility is determined by: a) the level of asset accumulation, b) the returns of those assets, and c) the cumulative impact of shocks (Baulch \& Hoddinott, 2000).

Chronic poverty is often the result of persistent poverty traps and intrinsic characteristics that condition the equilibrium level of well-being (Carter \& Barrett, 2006), such as the decision to invest in low return activities or underinvest in human capital. From a microeconomic perspective, poverty traps are related to a positive relationship between wealth and marginal returns, which can be the result of at least three circumstances: i) increasing returns to scale, ii) entry costs to high return activities, and iii) risk aversion (Carter \& Barrett, 2006). Market failures and individual behavioural responses under extreme scarcity may lead to poverty traps (Ghatak, 2015), as do expectations of the future that are related to underinvestment by the poor (Banerjee, et al., A multifaceted program causes lasting for the very poor: Evidence from six countries, 2015). ${ }^{36}$

Next to the positive effects of social transfers on income poverty and inequality, and on social outcomes such as attainments in education and health, they also affect economic performance at different levels. At the micro level, social transfers help households to alleviate credit constraints by fostering savings, investments, and access to credit. They allow households to smooth consumption, which may reduce transitory poverty, and to secure and accumulate assets by promoting access to economic opportunities. Moreover, social transfers help to cover transaction and transportation costs,

\footnotetext{
${ }^{36}$ For a recent discussion of poverty traps and the role of the aid transfers at the macro level, see Meysonnat et al. (2015). 
which enhances labour supply and fosters local economic effects (see Barrientos (2012), Alderman \& Yemtsov (2012), Tirivayi et al. (2013), and Mideros et al. (2016)).

Relating the potential economic returns of social transfers to the determinants of intra-generational mobility, social transfers help poor households to invest in both human and physical capital (i.e., accumulation of assets). Moreover, social transfers help households to confront negative economic shocks that otherwise may force them into asset destitution (Baulch $\&$ Hoddinott, 2000). In this case, social transfers, if permanent and reliable, allow poor households to smooth their consumption, solve liquidity constraints, and protect them against economic shocks. Given that intergenerational mobility is driven by two mechanisms, inheritance of endowments and the propensity of parents to invest in the human capital of their children (Rodríguez-Oreggia \& Freije, 2012), ${ }^{37}$ social transfers promote mobility between generations by helping poor households to accumulate more assets and to afford higher human capital investments, thereby breaking the intergenerational transmission of poverty. In this sense, we argue that social transfers should not be seen only from a protection perspective, but also as an instrument for economic inclusion and upward social mobility.

\subsubsection{Empirical evidence}

Literature on the effects of social transfers on social mobility in developing countries is scarce, in part due to the lack of long-term panel data. A study in Latin America found that intergenerational social mobility was lower in this region than in developed countries (Azevedo \& Bouillon, 2009).

\footnotetext{
${ }^{37}$ For seminal literature on the role of human capital and intergenerational mobility, see Becker \& Tomes (1986) (1994). For the importance of early child conditions on social mobility, see Heckman \& Mosso (2014).
} 
Correlation of intergenerational income for Chile, Brazil, and Peru were approximately 0.52 and 0.60 in comparison with United Kingdom (0.50), United States (0.47), France (0.41), Canada (0.19), and Nordic Countries (0.19). The authors explained these results as a lack of access to basic services and markets, labour market discrimination, low educational level, and credit constraints. Interestingly, they found that relative mobility was lower at the top of the income distribution, which meant that it was more likely that a poor person becomes non-poor, than a rich person becomes non-rich. The main factors that influenced social mobility were family background, market failures, access to basic services and markets, labour segmentation and discrimination, access to safety nets, and inheritances. In addition, the authors found low intra-generational social mobility, which they explained by the presence of poverty traps that were produced by lack of human and physical capital (Azevedo \& Bouillon, 2009). In the case of Ecuador, Cano (2015) found that income mobility was low for top incomes, which reflected structural inequalities, but education was a main driver of upward intragenerational mobility.

In the case of social transfers, it is important to note that they may be necessary, but not sufficient, for social mobility. In the words of Sandberg, "the possible impact on chronic poverty and exclusion rests on its ability to enable more than a temporary exit from poverty" (2012, p. 1355). Complementary policies regarding housing, coverage and quality of health and educational services, social exclusion and discrimination, gender equity, ${ }^{38}$ and economic inclusion are necessary to foster social mobility. For

\footnotetext{
${ }^{38}$ In most developing countries, large gender inequalities in the labour market exist against women, which reduces the returns of their labour participation. In addition, authors like Molyneux (2009) argued that conditional cash transfers entrapped women in patriarchal gender roles.

98
} 
example, social transfers may help to solve qualification deficits by promoting accumulation of human capital and liquidity constraints for one's own business investments, but they usually do not have a direct link with the labour market or with the expected returns of such assets. In this sense, complementary policies that provided professional training, self-employment support, labour intermediation, employment creation, and enhancement of the local economy were necessary to guarantee social mobility (Sandberg, 2012).

A qualitative social mobility analysis of the Uruguayan conditional cash transfer (CCT) Asignación Familiar (AFAM) did not find significant effects on residential segregation, educational segmentation, and labour market segmentation, which are necessary to break the intergenerational transmission of poverty and social exclusion (Sandberg, 2012). Sandberg concluded that "major socio-economic reforms and interventions are needed to correct structural inequalities, asymmetric processes and supply-side deficiencies, particularly in urban planning and development, the secondary education system, and the labour market" (2012, p. 1356), and that with higher transfer amounts and complementary active labour market policies, AFAM could help in such cases (2012).

In Mexico, Rodríguez-Oreggia \& Freije (2012) found little evidence of positive effects of the cash transfer programme Oportunidades on employment, wages, and intergenerational occupational mobility among a cohort of beneficiaries aged 14-24 in 2007. They did not find any significant effect on the probability of being employed, but a positive effect on wages was found only for males who were exposed to the program for at least six years. The authors argued that the positive effects of the programme operated only via the increase in educational level. For the same programme, Villa \& Niño-Zarazúa (2014) analysed poverty dynamics in the context of programme 
graduation (and hence, poverty), and they found that successful graduation was only achieved for $28.9 \%$ and $26.7 \%$ of beneficiary households in urban and rural areas, respectively.

However, Banerjee et al. (2015) evaluated multifaceted programmes in six countries, which included productive asset grants, training, life skills coaching, access to health information, and access to savings accounts in addition to temporary cash or food transfer. They found positive effects after one and three years of the intervention on consumption, household assets, food security, and income. They argued that this kind of programme provided a "big push" to unlock poverty traps. An important aspect related to this kind of programme is that they go beyond the traditional objective of consumption smoothing and accumulation of human capital by delivering synergies with productive activities. As such, they achieved a more sustainable reduction in poverty (Handa and Davis, 2006).

\subsection{Data and methods}

Contrary to poverty status at one point in time, which can be observed using cross sectional data, the analysis of social mobility and poverty transition requires longitudinal data to examine welfare trajectories over time (Baulch $\&$ Hoddinott, 2000). In this paper, we used administrative data from the Ecuadorian Registro Social (RS). The data were collected by the Coordinator Ministry of Social Development (MCDS), and included beneficiary and nonbeneficiary households at three points in time: 2002-2003, 2008-2009, and 2013-2014. Henceforth, we used the second year to refer to each period (e.g., 2003 for 2002-2003).

The RS was used to estimate a composite indicator (RS index) using principal components, and this provided a value between 0 and 100 for each 
household. The index was updated each period, whereby variables and weights changed. Hence, the indices were not directly comparable. Weights for each variable were estimated using household surveys as a proxy of consumption. They were provided by the MCDS to estimate the indices directly. The RS index is the instrument used to target the Ecuadorian Bono de Desarrollo Humano (BDH) and other social programmes in Ecuador.

The BDH was a cash transfer with soft conditionality (i.e., monitoring is weak) that children must attend school and health controls. It provided a flat transfer. In 2003, each beneficiary household received 15 USD per month irrespective of household size. The amount was increased in 2007, 2009, and 2013 to 30 USD, 35 USD, and 50 USD, respectively. ${ }^{39}$ The official RS index threshold to receive the BDH was defined for the lowest $40 \%$ in 2003, and as a proxy for the consumption poverty line at 50.6 points in 2009 and 36.5 points in 2014, respectively. An additional eligibility condition required the presence of school age children under 18 years old in the household.

The RS index was updated each time the RS information was collected. ${ }^{40}$ That is, the RS 2003 index used different variables and weights than the RS 2009 index, and the RS 2014 index. For instance, the RS 2003 index was estimated using 27 variables. However, there were only 23 variables available in 2009 and 25 variables in 2014. Therefore, it was necessary to impute the RS 2003 for the periods 2009 and 2014 to have a comparable welfare indicator. This was done by first estimating a partial index ( $R S 2003_{2009, j}^{23}$ and $\left.R S 2003_{2014, j}^{25}\right)$ using the available variables at

\footnotetext{
${ }^{39}$ My estimates based on official data showed that, on average, the BDH reflected at 15 USD $7 \%(12 \%)$ of the income (extreme) poverty line; at 30-35 USD it reflected $12 \%(22 \%)$, and at 50 USD it reflected $15 \%(27 \%)$.

40 The variables used to calculate the RS index (multidimensional welfare indicator) are presented in Annex 4.1.
} 
each period. Second, the RS 2003 index was imputed for each household $(j)$ using the equations below. Coefficients were estimated using a univariate linear regression model with a constant and assuming an independent and identically distributed (i.d.d.) error term with mean zero.

$R S 2 \widehat{003}_{2009, j}^{27}=7.976611+\left(1.149994 * R S 2003_{2009, j}^{23}\right)$

$R S \widehat{2003}_{2014, J}^{27}=2.104049+\left(1.078523 * R S 2003_{2014, j}^{25}\right)$

Similarly, we imputed the RS 2009 index for the period 2014. It included 30 variables, but only 28 variables were available in 2014. As in the previous case, the RS index was imputed subsequently using the following equation: $R S \widehat{2009_{2014, j}^{30}}=-2.711827+\left(1.102745 * R S 2009_{2014, j}^{28}\right)$

The data allowed us to build a panel to evaluate social mobility and the effect of the BDH over a decade. It is important to note that given the design of the RS as an instrument to evaluate poverty and vulnerability, households at the upper tail of the welfare distribution were not included. Hence, our analysis concentrated on low-welfare households. The panel followed 413,043 households over the three periods, of which $35 \%$ were headed by females. ${ }^{41}$ Average household median schooling increased from 4.8 to 5.4 years between 2003 and 2014, although household size decreased from 4.0 to 3.4. The average RS 2003 index increased from 43.9 in 2003 to 48.4 in 2009 and 53.3 in 2014 (Table 4.1).

As mentioned above, we used the RS index as a welfare indicator for the empirical analysis of social mobility, thereby taking into account the multidimensionality of human development, while focusing on the

\footnotetext{
${ }^{41}$ According to the population census of 2010, Ecuador had 3.8 million households with a total population of 14.5 million inhabitants.
}

102 
functioning space (i.e., what a person actually achieved). ${ }^{42}$ Table 4.2 shows general social mobility indicators. ${ }^{43}$ Between 2003 and 2009, 72.7\% of households experienced positive absolute mobility (i.e., welfare growth on the RS index). This percentage was higher between 2009 and 2014 when $77.4 \%-82.6 \%$ of households experienced positive absolute mobility. Over the entire period 2003-2014, this percentage was $87.9 \%$. However, in the case of relative upward mobility (i.e., moving to a higher percentile on the welfare distribution), mobility was slightly higher between 2003 and 2009 (48.7\% of households) than between 2009 and 2014 ( 46.5\% - 48.6\% of households). Both measures were complementary in the sense that absolute mobility showed that most of households improved their welfare level, although relative mobility indicated origin independence, but also risk and, in some cases, vulnerability.

It is possible to have positive relative mobility with negative absolute mobility, when those higher up the welfare distribution become absolutely worse off. The desirable scenario is having both positive absolute and relative mobility, because it indicates that everybody is better off, but that the final position on the welfare distribution is not conditioned to the initial condition.

Table 4.1. Descriptive statistics

\begin{tabular}{llrrr}
\hline & Variable & Observations & Mean & $\begin{array}{c}\text { Standard } \\
\text { deviation }\end{array}$ \\
\hline & RS index & & & \\
\hline RS 2003 in 2003 & & 413.043 & 43,93 & 9,00 \\
RS 2003 in 2009 & 413.043 & 48,36 & 8,58 \\
RS 2003 in 2014 & 413.043 & 53,30 & 9,00
\end{tabular}

\footnotetext{
${ }^{42}$ For a discussion on the operationalisation of the capability approach for poverty analysis, see Saith (2001).

${ }^{43}$ For a discussion on social mobility indexes, see Cowell \& Schluter (1998) and Jänti \& Jankins (2015).
} 


\begin{tabular}{|c|c|c|c|}
\hline RS 2009 in 2009 & 413.043 & 28,64 & 12,83 \\
\hline RS 2009 in 2014 & 413.043 & 36,80 & 13,88 \\
\hline \multicolumn{4}{|l|}{ Segmentation variables } \\
\hline Head of house is female (Yes $=1 / \mathrm{No}=0)$ & 413.043 & 0,35 & 0,00 \\
\hline Indigenous $(\mathrm{Yes}=1 / \mathrm{No}=0)$ & 413.043 & 0,15 & 0,00 \\
\hline Afroecuadorian $(\mathrm{Yes}=1 / \mathrm{No}=0)$ & 413.043 & 0,04 & 0,00 \\
\hline Montubio $(\mathrm{Yes}=1 / \mathrm{No}=0)$ & 413.043 & 0,11 & 0,00 \\
\hline Mestizo (including white and others) $(\mathrm{Yes}=1 / \mathrm{No}=0)$ & 413.043 & 0,71 & 0,00 \\
\hline Rural area $(\mathrm{Yes}=1 / \mathrm{No}=0)$ & 413.043 & 0,47 & 0,00 \\
\hline \multicolumn{4}{|l|}{ Human capital variables } \\
\hline Household's size in 2003 & 413.043 & 3,97 & 2,00 \\
\hline Household's size in 2009 & 413.043 & 3,77 & 1,97 \\
\hline Household's size in 2014 & 413.043 & 3,43 & 1,87 \\
\hline Household's dependency ratio in 2003 & 413.043 & 0,48 & 0,26 \\
\hline Household's dependency ratio in 2009 & 413.043 & 0,49 & 0,29 \\
\hline Household's dependency ratio in 2014 & 413.043 & 0,46 & 0,33 \\
\hline Household's median schooling in 2003 & 413.043 & 4,80 & 2,91 \\
\hline Household's median schooling in 2009 & 413.043 & 4,89 & 2,95 \\
\hline Household's median schooling in 2014 & 413.043 & 5,40 & 3,22 \\
\hline \multicolumn{4}{|l|}{ Physical capital variables } \\
\hline Household's number of durables in 2003 & 413.043 & 1,15 & 0,98 \\
\hline Household's number of durables in 2009 & 413.043 & 1,80 & 1,20 \\
\hline Household's number of durables in 2014 & 413.043 & 2,32 & 1,19 \\
\hline \multicolumn{4}{|l|}{ Labour variables } \\
\hline Share of working age with income in 2003 & 413.043 & 0,69 & 0,33 \\
\hline Share of working age with income in 2009 & 413.043 & 0,59 & 0,35 \\
\hline Share of working age with income in 2014 & 413.043 & 0,43 & 0,38 \\
\hline \multicolumn{4}{|l|}{ Change variables } \\
\hline Change in household's size between 2003 and 2009 & 413.043 & $-0,21$ & 1,62 \\
\hline Change in household's size between 2003 and 2014 & 413.043 & $-0,54$ & 2,00 \\
\hline Change in household's size between 2009 and 2014 & 413.043 & $-0,33$ & 1,24 \\
\hline Change in household's dependency ratio between 2003 and 2009 & 413.043 & $-0,15$ & 1,44 \\
\hline Change in household's dependency ratio between 2003 and 2014 & 413.043 & $-0,46$ & 1,83 \\
\hline Change in household's dependency ratio between 2009 and 2014 & 413.043 & $-0,31$ & 1,10 \\
\hline Change in median schooling between 2003 and 2009 & 413.043 & 0,09 & 2,66 \\
\hline Change in median schooling between 2003 and 2014 & 413.043 & 0,60 & 2,88 \\
\hline Change in median schooling between 2009 and 2014 & 413.043 & 0,51 & 2,35 \\
\hline Change in durables between 2003 and 2009 & 413.043 & 0,65 & 1,11 \\
\hline Change in durables between 2003 and 2014 & 413.043 & 1,17 & 1,18 \\
\hline Change in durables between 2009 and 2014 & 413.043 & 0,52 & 1,10 \\
\hline Change in share of working age with income between 2003 and 2009 & 413.043 & $-0,10$ & 0,39 \\
\hline Change in share of working age with income between 2003 and 2014 & 413.043 & $-0,26$ & 0,46 \\
\hline Change in share of working age with income between 2009 and 2014 & 413.043 & $-0,16$ & 0,44 \\
\hline
\end{tabular}

Note: Household dependency ratio was defined as the number of persons below 15 years old and above 64 years old, over total household size. The share of working age with income was the ratio between the number of persons 15-64 years old who received an income and the total number of working age members.

Source: Own calculation based on Registro Social 2002-2003, 2008-2009, and 2013-2014.

The Shorrock's mobility index compares the Gini of the total welfare indicator (adding up both periods) with the weighted average of the Gini in each period (Woolard \& Klasen, Determinants of Income Mobility and 
Household Poverty Dynamics in South Africa, 2005). ${ }^{44}$ A value of zero means no mobility, and one indicates perfect mobility. This index measures relative mobility, and in the case of the RS index in Ecuador, it shows a value of 0.11 comparing 2003 with 2014. This value was close to that found for income and expenditure in South Africa, which was also similar to that of Spain in the 1990s (0.1), but higher than the value in industrialized countries (0.05), as reported by Woolard \& Klasen (2005). The index was slightly higher in the period 2003-2009 than in 2009-2014. However, as upward absolute mobility was lower in the period 2003-2009, higher relative mobility can be seen as an indication of more risk and vulnerability compared to 20092014. In the absence of positive absolute mobility, relative mobility was driven by individuals getting worse off.

Table 4.2. Social mobility indicators.

\begin{tabular}{|c|c|c|c|c|c|}
\hline \multirow[t]{2}{*}{ Period } & \multicolumn{2}{|c|}{ Positive mobility* } & \multirow{2}{*}{$\begin{array}{c}\text { Shorrock's } \\
\text { mobility } \\
\text { index }\end{array}$} & \multicolumn{2}{|c|}{$\begin{array}{c}\text { Fields and Ok's per capita } \\
\text { mobility index }\end{array}$} \\
\hline & Absolute & Relative & & Total & Positive \\
\hline $2003-2009^{+}$ & $72.73 \%$ & $48.73 \%$ & 0.10 & 6.97 & 4.44 \\
\hline $2003-2014^{+}$ & $87.85 \%$ & $48.59 \%$ & 0.11 & 10.38 & 9.37 \\
\hline $2009-2014^{+}$ & $77.42 \%$ & $47.28 \%$ & 0.08 & 6.72 & 4.94 \\
\hline $2009-2014^{++}$ & $82.60 \%$ & $46.47 \%$ & 0.06 & 9.84 & 8.16 \\
\hline
\end{tabular}

${ }^{+}$RS 2003 index, ${ }^{++}$RS 2009 index

*Percentage of households with increased welfare indicator. Immobility was zero in the case of absolute mobility, and it accounted for $2.6 \%-3.3 \%$ in the case of relative mobility; the complement was negative mobility.

Source: Own calculation based on Registro Social 2002-2003, 2008-2009, and 2013-2014.

Finally, Fields and Ok's per capita mobility index measures absolute mobility as the average distance between the final and the initial welfare value. Although the total index adds up both positive and negative mobility

\footnotetext{
${ }^{44}$ It is important to note that the mobility index was equal to one minus the rigidity index used by Woolard \& Klasen (2005). The formula for the Shorrock's mobility index was then $1-\left\{G_{(x+y)} /\left[\left(\mu_{x} G_{x}+\mu_{y} G_{y}\right) /\left(\mu_{x}+\mu_{y}\right)\right]\right\}$, where $x$ and $y$ are periods, $\mu_{t}$ was the mean welfare value at period $t$, and $G_{t}$ was the Gini index for period $t$.
} 
in absolute terms, the positive index only includes upward mobility. ${ }^{45}$ Positive mobility was higher in the period 2009-2014 ( 4.9 - 8.2 RS index points) compared to 2003-2009 (4.4 RS index points). Overall, the different indicators provided evidence of social mobility in Ecuador; relative mobility was slightly higher between 2003 and 2009, but absolute mobility was higher between 2009 and 2014. In general, there was more upward mobility (being better off) in the period 2009-2014 than in 2003-3009, but at the same time the risk and vulnerability of getting worse off were higher.

In the next section, we assessed social mobility in three different ways. First, we considered the poverty transition matrix over the periods 2003, 2009, and 2014, which allowed us to identify structural mobility. Poverty lines were the RS index thresholds that were indicated previously to target the $\mathrm{BDH}$ and other social programmes in Ecuador. Second, we identified the determinants of social mobility both in absolute (welfare growth) and relative (changes in rank) terms. In both cases, we followed the model proposed by Woolard \& Klasen (2005) to analyse the determinants of welfare change. The underlying assumption was that household welfare $\left(W_{j}\right)$ was a function of physical $\left(K_{j}\right)$ and human $\left(H_{j}\right)$ assets, and labour $\left(L_{j}\right)$ and segmentation $\left(S_{j}\right)$ conditions. The dependent variable was the change in household welfare between periods:

$\Delta \log W_{j}=f\left(S_{j}, H_{j}, K_{j}, L_{j}\right)$.

We used a linear regression model to estimate the determinants of absolute mobility, which had the following specification:

$\ln W_{j, t}=\psi \log W_{j, t-1}+\alpha S_{j, t-1}+\beta H_{j, t-1}+\gamma K_{j, t-1}+\delta L_{j, t-1}+\theta C_{j, t}+\varepsilon_{j}$

45 Total mobility was measured as $\frac{1}{n} \sum_{j=1}^{n}\left|x_{j}-y_{j}\right|$, and positive mobility was calculated by $\frac{1}{n} \sum_{j=1}^{n}\left(x_{j}-y_{j}\right)$.

106 
where $W_{j, t}$ was the RS index for household $j$ at period t. $\psi, \alpha, \beta, \gamma, \delta$, and $\theta$ were vectors of coefficients. $C_{j}$ reflected changes in assets $(H$ and $K)$ and labour $(L)$ conditions between periods $t-1$ and $t$. $\varepsilon$ was a measure of unobservable characteristics that was assumed to be i.d.d. with mean zero. With respect to the determinants of relative mobility, we estimated the following logit model on the probability of a positive movement among percentiles:

$\operatorname{Pr}=\frac{1}{\left.1+e^{-\left(\rho \log W_{j, t-1}+\sigma S_{j, t-1}+\tau H_{j, t-1}+\varphi K_{j, t-1}+\omega L_{j, t-1}+\phi C_{j, t}+\pi j\right.}\right)}$

where $\rho, \sigma, \tau, \varphi, \omega$, and $\phi$ were vectors of coefficients, and $\pi$ was a measure of unobservable characteristics assumed to be i.d.d. with mean zero. The variables included in the models are discussed in the next section.

Finally, we estimated the effect of the BDH on absolute mobility by exploiting a difference-in-difference (DD) setting. The DD compares treatment $(T)$ and comparison $(C)$ groups in terms of outcomes. The average programme impact was defined as $E\left(Y_{1}^{T}-Y_{0}^{T} \mid T_{1}=1\right)-$ $E\left(Y_{1}^{C}-Y_{0}^{C} \mid T_{1}=0\right)$, where $t=1$ indicated time after programme implementation and $t=0$ indicated before, and $T_{1}=1$ denoted treated and $T_{1}=0$ denoted non-treated. The main assumption was that unobserved heterogeneity $\left(\sigma_{j, t}\right)$ was time invariant and uncorrelated with the treatment over time, which was likely to be the case once we included the available control variables for physical and human assets, labour characteristics, and segmentation conditions. Under a regression framework, the DD model was specified as:

$\log W_{j, t}=\lambda+\mu T_{j, 1} t+\xi T_{j, 1}+\eta t+\sigma_{j, t}$ 
where the interaction term between treatment and time $(\mu)$ was the DD effect, and $\eta$ estimated the effects of time and $\xi$ estimated the effect of being targeted (Khandker, Koolwal, \& Samad, 2010).

\subsection{Social mobility in Ecuador (2003-2014)}

Using the model and specifications presented in the previous section, we followed Woolard \& Klasen (2005) and we evaluated three "poverty traps" as determinants of social mobility: i) household composition, ii) low education, and iii) lack of physical capital and income generation opportunities.

To analyse poverty transitions, we used the RS 2003 index with the poverty threshold of 50.65 points. In $2003,77.9 \%$ of households in the panel had a RS index below the poverty threshold; this percentage decreased to $60.4 \%$ in 2009 and to $37.7 \%$ in 2014 . The probability to exit poverty between 2003 and 2009 was 29.3\% (see Panel A), and 44.8\% between 2009 and 2014 (see Panel B) (Table 4.3). On the other hand, the probability of becoming poor decreased from $24.2 \%$ in $2003-2009$ to $10.9 \%$ in $2009-2014$. Therefore, in terms of poverty transition, social mobility was positive in Ecuador.

Panel C in Table 4.3 shows that $31.9 \%$ of households were poor over the entire period; $23.2 \%$ were poor in 2003 and 2009, but left poverty in 2014; $19.2 \%$ were poor in 2003, but non-poor in 2009 and 2014; and $16.1 \%$ have never been poor. These figures were consistent with the idea that poverty reduction was sustained in Ecuador over the last decade.

These results can be related to changes in drivers of social mobility. Household size and dependency ratio decreased between 2003 and 2014, but at the same time, median schooling and ownership of durables increased. Moreover, changes in household median schooling and dependency ratio 
were higher between 2009 and 2014 ( 0.5 years / -0.3 points) than between 2003 and 2009 ( 0.1 years / -0.2 points). This may explain why positive social mobility, in terms of poverty reduction, was higher in 2009-2014 than in 2003-2009.

Table 4.3. Poverty transition matrix.

\begin{tabular}{|c|c|c|c|c|c|}
\hline \multicolumn{6}{|c|}{ Panel A } \\
\hline \multirow{2}{*}{\multicolumn{4}{|c|}{ 2003-2009 }} & \multicolumn{2}{|c|}{2009} \\
\hline & & & & Non-poor & Poor \\
\hline \multirow{2}{*}{\multicolumn{3}{|c|}{2003}} & Non-poor & $75.81 \%$ & $24.19 \%$ \\
\hline & & & Poor & $29.29 \%$ & $70.71 \%$ \\
\hline \multicolumn{6}{|c|}{ Panel B } \\
\hline \multirow{2}{*}{\multicolumn{4}{|c|}{ 2009-2014 }} & \multicolumn{2}{|c|}{2014} \\
\hline & & & & Non-poor & Poor \\
\hline \multirow{2}{*}{\multicolumn{3}{|c|}{2009}} & Non-poor & $89.08 \%$ & $10.92 \%$ \\
\hline & & & Poor & $44.79 \%$ & $55.21 \%$ \\
\hline \multicolumn{6}{|c|}{ Panel C } \\
\hline \multirow{2}{*}{\multicolumn{4}{|c|}{ 2003-2009-2014 }} & \multicolumn{2}{|c|}{2014} \\
\hline & & & & Non-poor & Poor \\
\hline \multirow{4}{*}{2003} & \multirow{2}{*}{ Non-poor } & \multirow{4}{*}{2009} & Non-poor & $16.10 \%$ & $0.67 \%$ \\
\hline & & & Poor & $3.86 \%$ & $1.49 \%$ \\
\hline & \multirow{2}{*}{ Poor } & & Non-poor & $19.16 \%$ & $3.65 \%$ \\
\hline & & & Poor & $23.21 \%$ & $31.87 \%$ \\
\hline
\end{tabular}

Source: Own calculation based on Registro Social 2002-2003, 2008-2009, and 2013-2014.

\subsubsection{Determinants of social mobility}

By exploring the determinants of social mobility, it is possible to analyse "poverty traps" (i.e., structural conditions that limit capabilities and opportunities of the poor), which must be addressed to promote positive mobility of the poor and the vulnerable. In Ecuador, which is a middle-income country ${ }^{46}$ with high inequality ${ }^{47}$, the elimination of poverty traps is necessary to achieve inclusive development by promoting economic growth together with poverty reduction and inequality decline.

${ }^{46}$ GNI per-capita (PPP, current international \$) was 11,070 USD in 2016 (World Bank, 2016).

${ }^{47}$ Gini coefficient was 45.4 in 2014 (World Bank, 2016). 
The selection of explanatory variables (Table 4.1) followed the literature on social mobility in the sense that "education, changes in employment and the demographic composition of the households play a large role in explaining existing mobility" (Woolard \& Klasen, 2005, p. 869). Initial conditions included dummy variables that accounted for segmentation characteristics (i.e., gender of the household head, ethnic group, and area of residence), human capital variables (i.e., household size, dependency ratio, and median schooling ${ }^{48}$ ), physical capital variables (i.e., number of durable goods ${ }^{49}$, including television, refrigerator, kitchen, telephone, and car), and labour variables (i.e., ratio between the number of persons 15-64 years old who received an income and the total number of working age members). In addition, change variables were calculated by subtracting initial from final values for human capital, physical capital, and labour variables. ${ }^{50}$

Absolute mobility was analysed by an RS index change regression that included the control variables already mentioned. The left side of Table 4.4 shows the results for the three periods of analysis. All variables had a significant effect on the RS index change. The initial RS index had a positive coefficient, which indicated that the higher the initial welfare indicator, the more likely the household was to experience absolute mobility (elasticity between 0.2 and 0.4 ). That is, there was increasing returns to scale; in other words, the poorer a household was, the less likely it was to experience welfare growth. All else being equal, female-headed households, indigenous and Montubio households, and rural households had lower absolute mobility than

\footnotetext{
${ }^{48}$ We used median schooling as a proxy for a household's productivity level.

${ }^{49}$ Durables were included as a proxy for physical capital. However, because they were also part of the RS index, we tested for collinearity using variance inflation factors.

${ }^{50}$ Although the inclusion of other variables can be debated, we were constrained by those variables that were available in the RS. 
male-headed households, mestizos-and-whites, and urban households, respectively. This indicated a persistent inequality against women, ethnic minorities (especially against indigenous and montubio ${ }^{51}$ populations), and rural areas. Separate estimates for urban and rural areas showed that the determinants of social mobility were similar, but that durables had a higher effect in rural areas. In addition, an alternative specification without the initial RS index provided similar results. ${ }^{52}$

An increase in the household size by one person reduced growth of the RS index by $2.2 \%-3.9 \%$ (Table 4.4 ). Similarly, a higher dependency ratio was related to lower RS index growth (except in the period 2003-2009). These results showed that large initial household size and higher dependency ratios were demographic poverty traps because they reduced absolute social mobility. An initial additional year of education (at the median) increased growth of the RS index by $0.6 \%-1.7 \%$, which indicated that low initial education also constrained social mobility. Initial physical capital measured by the ownership of durable goods had a positive effect on social mobility of $7.5 \%-11.4 \%$ for each additional durable good. The more physical capital a household possessed, the more it grew (i.e., increasing returns to scale). Initial income generating conditions had a positive effect on the growth of the RS index (except in the period 2009-2014 using the RS 2009). This hinted at a third poverty trap that was related to low access to work and physical capital. Finally, the highest effect was measured for durables among the change variables $(7.7 \%-14.6 \%)$. Other positive effects were related to increments in household median schooling and working age persons with activities that

\footnotetext{
${ }^{51}$ Montubios are peasant populations along the coast.

${ }^{52}$ Not presented here, but available upon request from the authors.
} 
generated income. On the other hand, absolute social mobility was reduced if household size or the dependency ratio increased.

Similar results were found for relative social mobility. Table 4.5 shows average marginal effects for a logit model for the probability of a positive movement among percentiles. A female-headed household has a probability to move up between 0.4 -3.7 percentage points lower than a male-headed household, all else being equal. As in the previous case, being indigenous or montubio, or living in a rural area, were related to a lower probability of social mobility. In the case of initial conditions, higher household size and dependency ratios reduced the probability of relative social mobility, but education, ownership of durables, and income generating activities had positive effects. The key change variables to promote relative social mobility were access to durables (physical capital) and income generating activities, which increased the probability of social mobility by 19.5-23.1 and 2.0-11.0 percentage points, respectively. On the other hand, a positive change in household size reduced the probability of relative social mobility by $3.7-7.9$ percentage points. 
Table 4.4. Determinants of absolute social mobility in Ecuador (2003-2009-2014).

\begin{tabular}{|c|c|c|c|c|c|c|c|c|}
\hline \multirow{2}{*}{ Variable } & \multicolumn{8}{|c|}{ RS index change regression (OLS) - $\log \mathrm{RS}$ index } \\
\hline & \multicolumn{2}{|c|}{ 2003-2009* } & \multicolumn{2}{|c|}{ 2003-2014* } & \multicolumn{2}{|c|}{ 2009-2014* } & \multicolumn{2}{|c|}{$2009-2014 * *$} \\
\hline Log RS index (initial) & $\begin{array}{r}0,245 \\
(0,002)\end{array}$ & $* * *$ & $\begin{array}{r}0,196 \\
(0,001)\end{array}$ & $* * *$ & $\begin{array}{r}0,329 \\
(0,002)\end{array}$ & $* * *$ & $\begin{array}{r}0,422 \\
(0,002)\end{array}$ & $* * *$ \\
\hline Head of house is female $(\mathrm{Yes}=1 / \mathrm{No}=0)$ & $\begin{array}{r}-0,002 \\
(0,000)\end{array}$ & $* * *$ & $\begin{array}{r}-0,008 \\
(0,000)\end{array}$ & $* * *$ & $\begin{array}{r}-0,013 \\
(0,000)\end{array}$ & $* * *$ & $\begin{array}{r}-0,004 \\
(0,001)\end{array}$ & $* * *$ \\
\hline Indigenous $(\mathrm{Yes}=1 / \mathrm{No}=0)$ & $\begin{array}{r}-0,060 \\
(0,001)\end{array}$ & $* * *$ & $\begin{array}{r}-0,041 \\
(0,001)\end{array}$ & $* * *$ & $\begin{array}{r}-0,027 \\
(0,001)\end{array}$ & $* * *$ & $\begin{array}{r}-0,034 \\
(0,002)\end{array}$ & $* * *$ \\
\hline Afroecuadorian $(\mathrm{Yes}=1 / \mathrm{No}=0)$ & $\begin{array}{r}0,000 \\
(0,001)\end{array}$ & & $\begin{array}{r}0,003 \\
(0,001)\end{array}$ & $* * *$ & $\begin{array}{r}0,002 \\
(0,001)\end{array}$ & $* * *$ & $\begin{array}{r}0,007 \\
(0,002)\end{array}$ & $* * *$ \\
\hline Montubio $(\mathrm{Yes}=1 / \mathrm{No}=0)$ & $\begin{array}{r}-0,011 \\
(0,000)\end{array}$ & $* * *$ & $\begin{array}{r}-0,014 \\
(0,000)\end{array}$ & $* * *$ & $\begin{array}{r}-0,012 \\
(0,000)\end{array}$ & $* * *$ & $\begin{array}{r}-0,061 \\
(0,001)\end{array}$ & $* * *$ \\
\hline Rural area $(\mathrm{Yes}=1 / \mathrm{No}=0)$ & $\begin{array}{r}-0,007 \\
(0,000)\end{array}$ & $* * *$ & $\begin{array}{r}-0,017 \\
(0,000)\end{array}$ & $* * *$ & $\begin{array}{r}-0,023 \\
(0,000)\end{array}$ & $* * *$ & $\begin{array}{r}-0,047 \\
(0,001)\end{array}$ & $* * *$ \\
\hline Head of house's age & $\begin{array}{r}0,001 \\
(0,000)\end{array}$ & $* * *$ & $\begin{array}{r}0,003 \\
(0,000)\end{array}$ & $* * *$ & $\begin{array}{r}0,003 \\
(0,000)\end{array}$ & $* * *$ & $\begin{array}{r}0,000 \\
(0,000)\end{array}$ & $* * *$ \\
\hline Household's size (initial) & $\begin{array}{r}-0,022 \\
(0,000)\end{array}$ & $* * *$ & $\begin{array}{r}-0,024 \\
(0,000)\end{array}$ & $* * *$ & $\begin{array}{r}-0,025 \\
(0,000)\end{array}$ & $* * *$ & $\begin{array}{r}-0,039 \\
(0,000)\end{array}$ & $* * *$ \\
\hline Household's dependency ratio (initial) & $\begin{array}{r}0,013 \\
(0,001)\end{array}$ & $* * *$ & $\begin{array}{r}-0,054 \\
(0,001)\end{array}$ & $* * *$ & $\begin{array}{r}-0,052 \\
(0,001)\end{array}$ & $* * *$ & $\begin{array}{r}-0,046 \\
(0,002)\end{array}$ & $* * *$ \\
\hline Household's median schooling (initial) & $\begin{array}{r}0,010 \\
(0,000) \\
\end{array}$ & $* * *$ & $\begin{array}{r}0,009 \\
(0,000) \\
\end{array}$ & $* * *$ & $\begin{array}{r}0,006 \\
(0,000) \\
\end{array}$ & $* * *$ & $\begin{array}{r}0,017 \\
(0,000)\end{array}$ & $* * *$ \\
\hline Household's number of durables (initial) & $\begin{array}{r}0,075 \\
(0,000) \\
\end{array}$ & $* * *$ & $\begin{array}{r}0,072 \\
(0,000) \\
\end{array}$ & $* * *$ & $\begin{array}{r}0,058 \\
(0,000) \\
\end{array}$ & $* * *$ & $\begin{array}{r}0,114 \\
(0,001) \\
\end{array}$ & $* * *$ \\
\hline Share of working age with income (initial) & $\begin{array}{r}0,029 \\
(0,001) \\
\end{array}$ & $* * *$ & $\begin{array}{r}0,028 \\
(0,001) \\
\end{array}$ & $* * *$ & $\begin{array}{r}0,017 \\
(0,001) \\
\end{array}$ & $* * *$ & $\begin{array}{r}-0,004 \\
(0,002) \\
\end{array}$ & ** \\
\hline Change in household's size & $\begin{array}{r}-0,027 \\
(0,000)\end{array}$ & $* * *$ & $\begin{array}{r}-0,028 \\
(0,000)\end{array}$ & $* * *$ & $\begin{array}{r}-0,028 \\
(0,000)\end{array}$ & $* * *$ & $\begin{array}{r}-0,033 \\
(0,001)\end{array}$ & $* * *$ \\
\hline Change in household's dependency ratio & $\begin{array}{r}-0,007 \\
(0,000)\end{array}$ & $* * *$ & $\begin{array}{r}-0,012 \\
(0,000)\end{array}$ & $* * *$ & $\begin{array}{r}-0,012 \\
(0,000)\end{array}$ & $* * *$ & $\begin{array}{r}-0,037 \\
(0,001)\end{array}$ & $* * *$ \\
\hline Change in median schooling & $\begin{array}{r}0,006 \\
(0,000)\end{array}$ & $* * *$ & $\begin{array}{r}0,006 \\
(0,000)\end{array}$ & $* * *$ & $\begin{array}{r}0,005 \\
(0,000)\end{array}$ & $* * *$ & $\begin{array}{r}0,014 \\
(0,000)\end{array}$ & $* * *$ \\
\hline Change in durables & $\begin{array}{r}0,087 \\
(0,000)\end{array}$ & $* * *$ & $\begin{array}{r}0,081 \\
(0,000)\end{array}$ & $* * *$ & $\begin{array}{r}0,077 \\
(0,000)\end{array}$ & $* * *$ & $\begin{array}{r}0,146 \\
(0,000)\end{array}$ & $* * *$ \\
\hline Change in share of working age with income & $\begin{array}{r}0,031 \\
(0,000)\end{array}$ & $* * *$ & $\begin{array}{r}0,036 \\
(0,000)\end{array}$ & $* * *$ & $\begin{array}{r}0,037 \\
(0,000)\end{array}$ & $* * *$ & $\begin{array}{r}0,008 \\
(0,001)\end{array}$ & $* * *$ \\
\hline $\begin{array}{l}\text { Number of observations } \\
\text { Adjusted R2 }\end{array}$ & $\begin{array}{r}413.0 \\
0,75\end{array}$ & & $\begin{array}{r}413.0 \\
0,75\end{array}$ & & $\begin{array}{r}413.0 \\
0,76\end{array}$ & & $\begin{array}{r}412.9 \\
0,710\end{array}$ & \\
\hline
\end{tabular}

Note: Heteroskedasticity consistent standard errors are between brackets. All estimates included a constant and dummy variable at the province level (not reported). Variance inflation factor (VIF) was lower than 5 for all variables in any model, showing that collinearity was not a problem. Adjusted R2 was higher than 0.71 in all the OLS models.

$+\mathrm{RS}$ index 2003, $++\mathrm{RS}$ index 2009; *** Significance at $1 \%$, ** significance at 5\%, * significance at $10 \%$.

Source: Own calculation based on Registro Social 2002-2003, 2008-2009 and 2013-2014. 
Table 4.5. Determinants of relative social mobility in Ecuador (2003-2009-2014).

\begin{tabular}{|c|c|c|c|c|c|c|c|c|}
\hline \multirow{3}{*}{$\begin{array}{r}\text { Variable } \\
\text { Log RS index (initial) }\end{array}$} & \multicolumn{8}{|c|}{$\begin{array}{c}\text { Probability of a positive rank change (percentile) - average } \\
\text { marginal effect }\end{array}$} \\
\hline & \multicolumn{2}{|c|}{ 2003-2009* } & \multicolumn{2}{|c|}{ 2003-2014* } & \multicolumn{2}{|c|}{ 2009-2014* } & \multicolumn{2}{|c|}{$2009-2014 * *$} \\
\hline & $\begin{array}{r}-1,422 \\
(0,006) \\
\end{array}$ & $* * *$ & $\begin{array}{r}-1,492 \\
(0,006)\end{array}$ & $* * *$ & $\begin{array}{r}-1,671 \\
(0,007) \\
\end{array}$ & $* * *$ & $\begin{array}{r}-0,474 \\
(0,002) \\
\end{array}$ & $* * *$ \\
\hline $\begin{array}{l}\text { Head of house is female }(\mathrm{Yes}=1 / \\
\mathrm{No}=0)\end{array}$ & $\begin{array}{r}-0,004 \\
(0,001)\end{array}$ & $* *$ & $\begin{array}{r}-0,020 \\
(0,001)\end{array}$ & $* * *$ & $\begin{array}{r}-0,037 \\
(0,001)\end{array}$ & $* * *$ & $\begin{array}{l}-0,008 \\
(0,002)\end{array}$ & $* * *$ \\
\hline Indigenous $(\mathrm{Yes}=1 / \mathrm{No}=0)$ & $\begin{array}{r}-0,127 \\
(0,002)\end{array}$ & $* * *$ & $\begin{array}{r}-0,083 \\
(0,002)\end{array}$ & $* * *$ & $\begin{array}{r}-0,081 \\
(0,002)\end{array}$ & $* * *$ & $\begin{array}{r}-0,030 \\
(0,003)\end{array}$ & $* * *$ \\
\hline Afroecuadorian $(\mathrm{Yes}=1 / \mathrm{No}=0)$ & $\begin{array}{r}0,003 \\
(0,003)\end{array}$ & & $\begin{array}{r}0,008 \\
(0,003)\end{array}$ & $* *$ & $\begin{array}{r}0,009 \\
(0,003)\end{array}$ & $* *$ & $\begin{array}{r}0,007 \\
(0,004)\end{array}$ & * \\
\hline Montubio $(\mathrm{Yes}=1 / \mathrm{No}=0)$ & $\begin{array}{r}-0,029 \\
(0,002)\end{array}$ & $* * *$ & $\begin{array}{r}-0,030 \\
(0,002)\end{array}$ & $* * *$ & $\begin{array}{r}-0,030 \\
(0,002)\end{array}$ & $* * *$ & $\begin{array}{l}-0,068 \\
(0,002)\end{array}$ & $* * *$ \\
\hline Rural area $(\mathrm{Yes}=1 / \mathrm{No}=0)$ & $\begin{array}{r}-0,015 \\
(0,001)\end{array}$ & $* * *$ & $\begin{array}{r}-0,036 \\
(0,001)\end{array}$ & $* * *$ & $\begin{array}{r}-0,062 \\
(0,001)\end{array}$ & $* * *$ & $\begin{array}{r}-0,049 \\
(0,001)\end{array}$ & $* * *$ \\
\hline Head of house's age & $\begin{array}{r}0,001 \\
(0,000) \\
\end{array}$ & $* * *$ & $\begin{array}{r}0,006 \\
(0,000) \\
\end{array}$ & $* * *$ & $\begin{array}{r}0,008 \\
(0,000) \\
\end{array}$ & $* * *$ & $\begin{array}{r}-0,001 \\
(0,000) \\
\end{array}$ & $* * *$ \\
\hline Household's size (initial) & $\begin{array}{r}-0,049 \\
(0,000)\end{array}$ & $* * *$ & $\begin{array}{r}-0,056 \\
(0,001)\end{array}$ & $* * *$ & $\begin{array}{r}-0,069 \\
(0,001)\end{array}$ & $* * *$ & $\begin{array}{r}-0,039 \\
(0,001)\end{array}$ & $* * *$ \\
\hline $\begin{array}{l}\text { Household's dependency ratio } \\
\text { (initial) }\end{array}$ & $\begin{array}{r}0,049 \\
(0,003)\end{array}$ & $* * *$ & $\begin{array}{r}-0,138 \\
(0,003)\end{array}$ & $* * *$ & $\begin{array}{r}-0,171 \\
(0,003)\end{array}$ & $* * *$ & $\begin{array}{r}-0,072 \\
(0,003)\end{array}$ & $* * *$ \\
\hline $\begin{array}{l}\text { Household's median schooling } \\
\text { (initial) }\end{array}$ & $\begin{array}{r}0,025 \\
(0,000)\end{array}$ & $* * *$ & $\begin{array}{r}0,021 \\
(0,000)\end{array}$ & $* * *$ & $\begin{array}{r}0,014 \\
(0,000)\end{array}$ & $* * *$ & $\begin{array}{r}0,020 \\
(0,000)\end{array}$ & $* * *$ \\
\hline $\begin{array}{l}\text { Household's number of durables } \\
\text { (initial) }\end{array}$ & $\begin{array}{r}0,162 \\
(0,001) \\
\end{array}$ & $* * *$ & $\begin{array}{r}0,165 \\
(0,001)\end{array}$ & $* * *$ & $\begin{array}{r}0,154 \\
(0,001)\end{array}$ & $* * *$ & $\begin{array}{r}0,129 \\
(0,001)\end{array}$ & $* * *$ \\
\hline $\begin{array}{l}\text { Share of working age with income } \\
\text { (initial) }\end{array}$ & $\begin{array}{r}0,074 \\
(0,003) \\
\end{array}$ & $* * *$ & $\begin{array}{r}0,070 \\
(0,002) \\
\end{array}$ & $* * *$ & $\begin{array}{r}0,040 \\
(0,003) \\
\end{array}$ & $* * *$ & $\begin{array}{r}-0,010 \\
(0,003) \\
\end{array}$ & $* * *$ \\
\hline Change in household's size & $\begin{array}{r}-0,066 \\
(0,001)\end{array}$ & $* * *$ & $\begin{array}{r}-0,072 \\
(0,001)\end{array}$ & $* * *$ & $\begin{array}{r}-0,079 \\
(0,001)\end{array}$ & $* * *$ & $\begin{array}{r}-0,037 \\
(0,001)\end{array}$ & $* * *$ \\
\hline $\begin{array}{l}\text { Change in household's dependency } \\
\text { ratio }\end{array}$ & $\begin{array}{r}-0,023 \\
(0,001)\end{array}$ & $* * *$ & $\begin{array}{r}-0,029 \\
(0,001)\end{array}$ & $* * *$ & $\begin{array}{r}-0,042 \\
(0,001)\end{array}$ & $* * *$ & $\begin{array}{r}-0,052 \\
(0,001)\end{array}$ & $* * *$ \\
\hline Change in median schooling & $\begin{array}{r}0,014 \\
(0,000)\end{array}$ & $* * *$ & $\begin{array}{r}0,016 \\
(0,000)\end{array}$ & $* * *$ & $\begin{array}{r}0,014 \\
(0,000)\end{array}$ & $* * *$ & $\begin{array}{r}0,018 \\
(0,000)\end{array}$ & $* * *$ \\
\hline Change in durables & $\begin{array}{r}0,216 \\
(0,000)\end{array}$ & $* * *$ & $\begin{array}{r}0,202 \\
(0,001)\end{array}$ & $* * *$ & $\begin{array}{r}0,231 \\
(0,001)\end{array}$ & $* * *$ & $\begin{array}{r}0,195 \\
(0,001)\end{array}$ & $* * *$ \\
\hline $\begin{array}{l}\text { Change in share of working age } \\
\text { with income }\end{array}$ & $\begin{array}{r}0,086 \\
(0,002) \\
\end{array}$ & $* * *$ & $\begin{array}{r}0,095 \\
(0,002) \\
\end{array}$ & $* * *$ & $\begin{array}{r}0,110 \\
(0,002) \\
\end{array}$ & $* * *$ & $\begin{array}{r}0,020 \\
(0,002) \\
\end{array}$ & $* * *$ \\
\hline Number of observations & 413.04 & & 413.0 & & 413.04 & & 413.0 & \\
\hline
\end{tabular}

Note: Heteroskedasticity consistent standard errors are between brackets. All estimates included a constant and dummy variable at the province level (not reported). Variance inflation factor (VIF) was lower than 5 for all variables in any model, showing that collinearity was not a problem. Adjusted R2 was higher than 0.71 in all the OLS models. $+\mathrm{RS}$ index 2003, $++\mathrm{RS}$ index 2009; *** Significance at $1 \%$, ** significance at 5\%, * significance at $10 \%$.

Source: Own calculation based on Registro Social 2002-2003, 2008-2009 and 2013-2014. 


\subsubsection{The effect of social transfers on social mobility}

The Ecuadorian cash transfer programme Bono de Desarrollo Humano (BDH) was targeted at poor households with children below 18 years old. Eligibility thresholds using the RS 2003 and RS 2009 indices were 50.65 and 36.50 points, respectively. By using this targeting rule and by exploiting a difference-in-difference (DD) model, we first estimated the intention to treat effect (ITT) in two periods: 2003-2009 and 2009-2014. Given that there were no administrative data to identify actual recipients of the BDH before 2009, we calculated the effect on those who we supposed to receive it. Second, additional administrative records available for the second period (20092014), which indicated actual BDH recipients, allowed us to estimate average treatment effects (ATE). Finally, we calculated the effect of the per-capita value of the $\mathrm{BDH}$, and the effect of an alternative design of the cash transfer programme called Crédito de Desarrollo Humano (CDH), among those who received the $\mathrm{BDH}$. The difference between the $\mathrm{BDH}$ and the $\mathrm{CDH}$ was that the latter paid a yearly amount aimed at promoting productive investments, but the $\mathrm{BDH}$ was a monthly transfer that guaranteed a minimum level of consumption. The $\mathrm{CDH}$ could be requested only by households that were active recipients of the $\mathrm{BDH}$.

The DD coefficient for the ITT effect of the BDH showed a positive and significant effect (Table 4.6). Being eligible for the BDH increased the RS index by $11.1 \%$ and $14.8 \%$ in 2003-2009 and 2009-2014, respectively. As in the previous models, household size and dependency ratios were negatively related to the RS index. The same effect (14.8\%) was found for the period 2009-2014 using an expanded data set with a panel of 1,258,462 households 
(Table 4.7). ${ }^{53}$ The effect of actually receiving the $\mathrm{BDH}$ resulted in an increase in the RS index of $12.0 \%-13.6 \%$, which was slightly lower than the estimated ITT for the same period. The BDH affected household welfare, not only temporarily, but also in the longer term, thereby fostering social mobility.

Estimates using households that received the BDH between 2009 and 2014 showed that a $10 \%$ higher transfer amount (3 USD per month) was related with a $0.79 \%-0.86 \%$ higher RS index. Finally, those households that received the $\mathrm{CDH}$ had a $4.0 \%-4.2 \%$ higher RS index than those households that received the $\mathrm{BDH}$ only. These results indicated that social transfers should not only be seen as an instrument to protect consumption, but also as a tool to foster social mobility. Moreover, the size of the transfer mattered in this context, and social transfers that had an explicit productive objective had an even stronger effect on absolute mobility, which was consistent with international evidence (see for example Banerjee et al. (2015)).

\footnotetext{
${ }^{53} \mathrm{We}$ used the enlarged panel for comparative purposes. On top of the 413,043 households from the original panel, it included another 845,419 households (in RS 2009 and RS 2014, but not in RS 2003). 


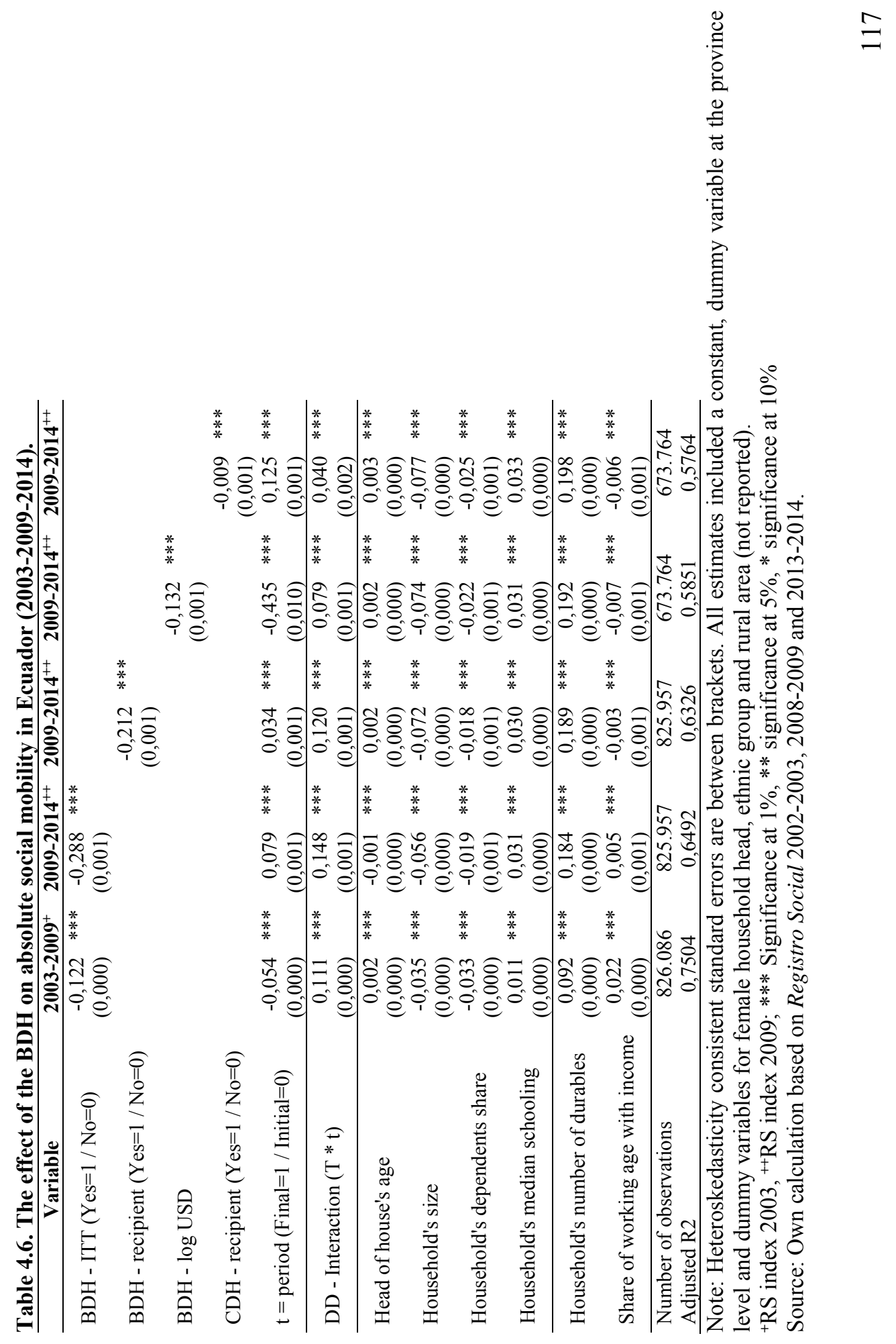




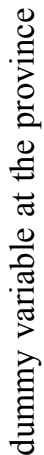

ชิ

焉

$\stackrel{8}{\stackrel{0}{\sigma}}$

它 $\dot{8}$

응

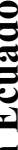

(1)

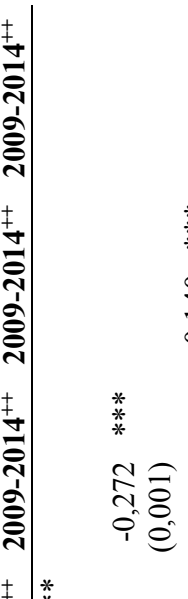

8

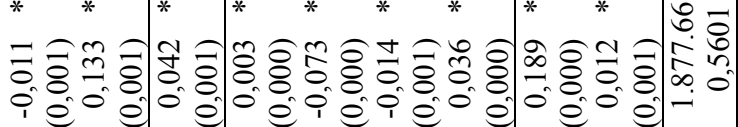

믄

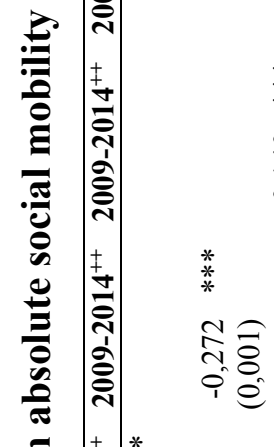

ప

$+\frac{*}{*} *$

商

๑ ڤิ

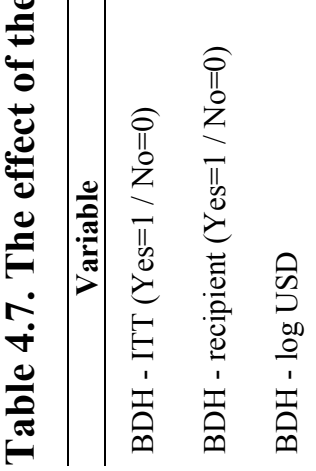

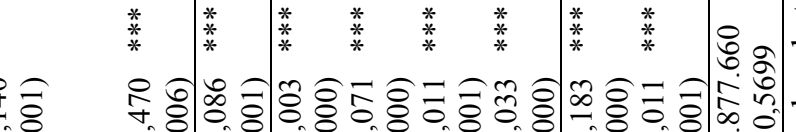
i

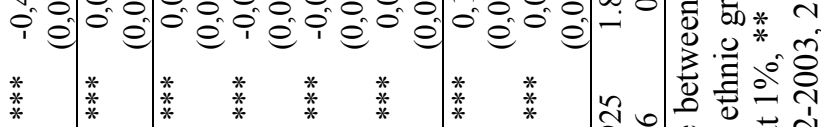
ชิ పิ

चี च

㐘* त्र एँ 䨔芯司

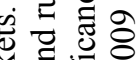

西

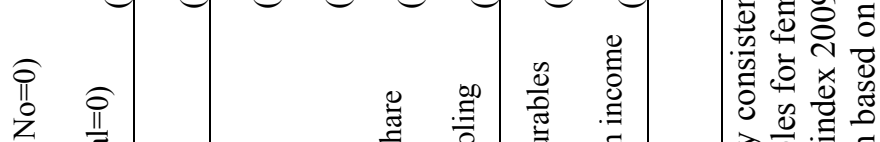




\subsection{Final remarks}

Social protection programs are now implemented in many low and middleincome countries, due to their efficacy in reducing poverty, vulnerability, and inequality. Over the last decade, evidence on the positive effects of investments in social protection has accumulated. However, the literature is scarce regarding long-term effects of social transfers on human development, such as the effects on social mobility and chronic poverty. This study contributes to literature on social mobility and cash transfers by analysing the determinants of upward mobility in Ecuador using a multivariate index (RS index), and by evaluating the effect of the social transfer programme called Bono de Desarrollo Humano (BDH).

Female-headed households, indigenous, Montubio, and rural households had lower absolute mobility compared to male-headed households, mestizosand-whites, and urban households, respectively. This indicated that inequalities persist against women, ethnic minorities, and rural areas. Also, large initial household size and higher dependency ratios should be considered as a demographic poverty trap in the sense that these conditions reduced absolute social mobility. Similarly, low initial education and the lack of physical capital and income generating opportunities constrained social mobility. In the case of change variables, higher effects were found for physical capital. Other positive effects were related to increments in household median schooling and working age persons with income generating activities. On the other hand, social mobility was reduced if household size or the dependency ratio increased.

Evaluating the BDH using a difference-in-difference setting, we found a positive intent-to-treat effect on absolute social mobility during the periods 2003-2009 and 2009-2014. The average treatment effect was the same for 
those who actually received the BDH in the period 2009-2014. Additional estimates showed that the amount of the transfer was important, which may be related to the possibility to cover demographic and physical capital poverty traps. Finally, we found evidence that suggested that social transfers aimed not only at guaranteeing a minimum level of consumption, but also at promoting productive investments, had a higher effect on multivariate social mobility.

These results indicated that to enable social mobility, anti-poverty policies should be geared towards improving access to physical capital and income generating activities (i.e., labour) and the accumulation of human capital, thereby promoting reproductive health, fostering gender equity, and reducing welfare and opportunity gaps between ethnic groups and among urban and rural areas. To solve poverty traps, social protection instruments should consider household composition and economic vulnerabilities, and they should be complemented with policies that strengthen the determinants of upward social mobility. Moreover, social transfers should not only be assessed by their impact on the smoothing of household consumption, but they should be assessed also as an instrument that can foster social mobility, due to their potential to solve different poverty traps.

\subsection{References}

Alderman, H., \& Yemtsov, R. (2012). Productive role of safety nets. Washington D.C.: The World Bank.

Alkire, S. (2002). Dimensions of human development. World Development, 30(2), 181-205.

Arnold, C., Conway, T., \& Greenslade, M. (2011). Cash transfers. Department for International Development, DFID. 
Azevedo, V., \& Bouillon, C. (2009). Social Mobility in Latin America: A Review of Existing Evidence. Washington D.C.: Interamerican Development Bank.

Banerjee, A., Duflo, E., Goldberg, N., Karlan, D., Osel, R., Pariente, W., . . . Udry, C. (2015). A multifaceted program causes lasting for the very poor: Evidence from six countries. Science, 348. doi:10.1126/science.1260799

Barrientos, A. (2012). Social transfers and growth: What do we know? What do we need to find out? World Development, 40(1), 11-20.

Barrientos, A., \& Niño-Zarazúa, M. (2010). Effects of non-contributory social transfers in developing countries: A compendium. Geneva: International Labour Organization.

Barrientos, A., \& Scott, J. (2008). Social transfers and growth: A review. BWPI Working Paper.

Bastagli, F., Hagen-Zanker, J., Harman, L., Barca, V., Sturge, G., Schmidt, T., \& Pellerano, L. (2016). Cash transfers: what does the evidence say? London: Overseas Development Institute.

Baulch, B., \& Hoddinott, J. (2000). Economic mobility and poverty dynamics in developing countries. Journal of Development Studies, 36(6), 1-24.

Becker, G., \& Tomes, N. (1986). Human Capital and the Rise and Fall of Families. Journal of Labor Economics, 4(2), S1-S39.

Becker, G., \& Tomes, N. (1994). Human Capital and the Rise and Fall of Families. In G. Becker, Human Capital: A Theoretical and Empirical Analysis with Special Reference to Education (pp. 257-298). The University of Chicago.

Cano, L. (2015). Income mobility in Ecuador. New evidence from individual income tax returns. Helsinki: WIDER Working Paper 2015/040. 
Carter, M., \& Barrett, C. (2006). The economics of poverty traps and persistent poverty: An asset-based approach. Journal of Development Studies, 42(2), 178-199.

Cowell, F., \& Schluter, C. (1998). Income Mobility: A Robust Apporach. London: The Toyota Centre, London School of Economics and Political Science, DARP/37.

Crawford, C., Johnson, P., Machin, S., \& Vignoles, A. (2011). Social Mobility: A Literature Review. London: Department for Business, Innovation \& Skills.

Funkada-Parr, S. (2003). The human development paradigm: Operationalizing Sen's ideas on capabilities. Feminist Economics, 9(2-3), 301-317.

Ghatak, M. (2015). Theories of Poverty Traps and Anti-Poverty Policies. The World Bank Economic Review, 1-29.

Gottschalk, P., \& Spolaore, E. (2002). On the evaluation of economic mobility. Review of Economic Studies, 69, 191-208.

Handa, S., \& Davis, B. (2006). The Experience of Conditional Cash Transfers in Latin America. Development Policy Review, 24(5), 513-536.

Heckman, J., \& Mosso, S. (2014). The economics of human development and social mobility. Bonn: IZA Discussion Paper 8000.

Hulme, D., \& Shepherd, A. (2003). Conceptualizing Chronic Poverty. World Development, 31(3), 403-423.

Hulme, D., Moore, K., \& Shepherd, A. (2001). Chronic poverty: meanings and analytical frameworks. Oxford: Institite of Development Policy Management. 
IEG. (2011). Evidence and Lessons Learned from Impact Evaluations on Social Safety NEts. Washington DC: Independent Evaluation Group, IEG. World Bank, IFC, MIGA.

Jalan, J., \& Ravallion, M. (2000). Is transient poverty different? Evidence for rural China. Journal of Development Studies, 36(6), 92-99. doi:10.1080/00220380008422655

Jäntti, M., \& Jenkins, S. (2015). Income mobility. In A. Atkinson, \& F. Bourguignon, Handbook of Income Distribution (pp. 807-935). Oxford: Elsevier.

Khandker, S., Koolwal, G., \& Samad, H. (2010). Handobook on Impact Evaluation. Quantitative Methods and Practices. Washington D.C.: The World Bank.

Lambert, S., Ravallion, M., \& van de Walle, D. (2014). Intergenerational mobility and interpersonal inequality in an African economy. Journal of Development Economics, 110, 327-344.

McCulloch, N., \& Baulch, B. (2000). Simulating the impact of policy upon chronic and transitory poverty in rural Pakistan. Journal of Development Studies, 36(6), 100-130.

Meysonnat, A., Muysken, J., \& van Zoon, A. (2015). Poverty traps: the neglected role of vitaly. Maastricht: UNU-MERIT Working Paper 2015-052.

Mideros, A., Gassmann, F., \& Mohnen, P. (2012). Estimation of rates of return of social protection instruments in Cambodia. A case for noncontributory social transfers. Maastricht: Maastricht Graduate School of Governance (MGSoG). 
Mideros, A., Gassmann, F., \& Mohnen, P. (2016). Estimation of rates of return on social protection: ex ante microsimulation of social transfers in Cambodia. Journal of Development Effectiveness, 8(1), 67-86.

Molyneux, M. (2009). Conditional cash transfers: A pathway to wome's empowerment? London: Department of International Development (DFID).

Robeyns, I. (2005). The capability approach: A theoretical survey. Journal of Human Development, 6(1), 93-117.

Rodríguez-Oreggia, E., \& Freije, S. (2012). Long term impact of a Cashtransfers program on labor outcomes of the rural youth. Cambridge: Center for International Development Working Paper 230.

Saith, R. (2001). Capabilities: The concept and its operationalisation. Ocford: Queen Elizabeth House Working Paper QEHWPS66.

Sandberg, J. (2012). Conditional cash transfers and social mobility: The role of asymmetric structures and segmentation processes. Development and change, 43(6), 1337-1359.

Tirivayi, N., Knowles, M., \& Davis, B. (2013). The interaction between social protection and agriculture. Rome: Food and Agriculture Organization (FAO).

UNICEF. (2012). Integrated Social Protection Systems. Enhancing Equity for Children. New York: United Nations Children's Fund.

Villa, J., \& Niño-Zarazúa, M. (2014). Poverty dynamics and programme graduation from social protection. Helsinki: WIDER Working Paper 2014/109.

Woolard, I., \& Klasen, S. (2005). Determinants of Income Mobility and Household Poverty Dynamics in South Africa. Journal of Development Studies, 41(5), 865-897. 
World Bank. (2015). The State of Social Safety Nets. Washington D.C.: The World Bank.

World Bank. (2016). World Bank Open Data. Retrieved 10 16, 2016, from http://data.worldbank.org/ 
Annex 4.1. Variables included in RS index and 2008

\begin{tabular}{|c|c|c|c|c|}
\hline \multirow{2}{*}{ Variables RS 2004} & \multicolumn{2}{|c|}{ Replica } & \multirow{2}{*}{ Variables RS 2009} & \multirow{3}{*}{$\begin{array}{c}\text { Replica } \\
\mathbf{2 0 1 4} \\
(28 \\
\text { variables }) \\
\end{array}$} \\
\hline & 2009 & 2014 & & \\
\hline (27 variables) & $\begin{array}{c}(23 \\
\text { variables })\end{array}$ & $\begin{array}{c}(25 \\
\text { variables })\end{array}$ & (30 variables) & \\
\hline Area of residence: urban / rural & Yes & Yes & Area of residence: urban / rural & Yes \\
\hline Floor materials & Yes & Yes & Floor materials & Yes \\
\hline Electricity & Yes & Yes & Shower & Yes \\
\hline Shower & Yes & Yes & Toilet facility & Yes \\
\hline Toilet facility & Yes & Yes & Garbage disposal & Yes \\
\hline Cooking fuel & Yes & Yes & Treatment to drinking water & Yes \\
\hline Land ownership & Yes & Yes & Wall materials & Yes \\
\hline Overcrowding & Yes & Yes & Access to drinking water & Yes \\
\hline $\begin{array}{l}\text { Number of children below } 6 \\
\text { years old }\end{array}$ & Yes & Yes & Roof materials & Yes \\
\hline $\begin{array}{l}\text { Working age persons without } \\
\text { income }\end{array}$ & Yes & Yes & Quality of dwelling & Yes \\
\hline Language & Yes & Yes & Road to housing & Yes \\
\hline Household's head education level & Yes & Yes & Access to internet & Yes \\
\hline Spouse education level & Yes & Yes & $\begin{array}{l}\text { Location of water and toilet } \\
\text { facilities }\end{array}$ & Yes \\
\hline Social security coverage & Yes & Yes & Household's size & Yes \\
\hline Access to credit & Yes & Yes & Overcrowding & Yes \\
\hline Ownership of kitchen & Yes & Yes & $\begin{array}{l}\text { Household's head education } \\
\text { level }\end{array}$ & Yes \\
\hline Ownership of television & Yes & Yes & Ownership of mobile phone & Yes \\
\hline Ownership of refrigerator & Yes & Yes & Ownership of television & Yes \\
\hline Ownership of telephone & Yes & Yes & Ownership of refrigerator & Yes \\
\hline Ownership of car & Yes & Yes & Ownership of telephone & Yes \\
\hline Ownership of radio & & Yes & Ownership of car & Yes \\
\hline Ownership of video recorder & & & $\begin{array}{l}\text { Ownership of washing } \\
\text { machine }\end{array}$ & Yes \\
\hline $\begin{array}{l}\text { Number of children not attending } \\
\text { to school }\end{array}$ & Yes & Yes & Ownership of computer & Yes \\
\hline $\begin{array}{l}\text { Children assisting to public } \\
\text { education }\end{array}$ & Yes & Yes & Ownership of oven & Yes \\
\hline $\begin{array}{l}\text { Number of life-born children who } \\
\text { died }\end{array}$ & & & Ownership of blender & Yes \\
\hline Last life-born children alive & & Yes & Ownership of iron & Yes \\
\hline $\begin{array}{l}\text { Number of persons with } \\
\text { disabilities }\end{array}$ & Yes & Yes & $\begin{array}{l}\text { Scholarships, pensions or } \\
\text { rental income }\end{array}$ & \\
\hline & & & $\begin{array}{l}\text { Children assisting to public } \\
\text { education }\end{array}$ & Yes \\
\hline & & & $\begin{array}{l}\text { Number of children below } 14 \\
\text { years old } \\
\text { Poverty index at the parish } \\
\text { level }\end{array}$ & Yes \\
\hline
\end{tabular}

Source: Own calculation based on Registro Social 2002-2003, 2008-2009 and 2012-2013. 


\section{Chapter 5 - The rate of return of non-contributory social}

\section{protection $^{54}$}

\subsection{Introduction}

Social protection is being promoted as a mechanism to reduce poverty and inequality, but also to promote human development. Several studies have estimated the potential benefits of social protection mechanisms and their financial affordability. However, only a limited number of studies so far have estimated the long-term economic return of such investments in social protection. Moreover, no study has estimated dynamic effects of noncontributory social transfers at the micro-level in developing countries by following individuals over time. ${ }^{55}$ This paper intends to fill this gap, analysing non-contributory social transfers and their role in socio-economic development.

Non-contributory social transfers directly affect household disposable income and, subject to the marginal propensity to consume, the level of consumption. This is the direct distributional effect, which depends on the design of benefits, their monetary levels, and targeted groups (Notten and Gassmann 2008), and on administrative capacity. Barrientos (2005) estimated

\footnotetext{
54 This paper was published as: Mideros, A., Gassmann, F. \& Mohnen, P. (2016). Estimation of rates of return on social protection: ex ante microsimulation of social transfers in Cambodia. Journal of Development Effectiveness, 8(1), 67-86.

${ }^{55}$ Recent studies have estimated economic effects of social transfers in African countries (see Thome et al. 2013 and 2014 (Give both citations here and for Taylor), Taylor et al. 2013 and 2014, Kagin et al. 2014). However, these studies analyzed the effect at the meso (community)-level and not the micro (household or individual)-level. A micro-level approach was used by Debowicz and Golan (2014) and McKee and Todd (2011), however, they did not follow individuals over time. Finally, several dynamic microsimulation models have been used to simulate the effects of pensions and tax reforms, especially in developed countries, but less attention has been provided to non-contributory social protection instruments in developing countries.
} 
that social pensions reduced the poverty head count ratio by $18.0 \%$ in Brazil and $12.5 \%$ in South Africa. Arnold, Conway, and Greenslade (2011) found that there was a reduction in the poverty gap in Mexico of $20 \%$, thanks to Oportunidades (a conditional cash transfer program) and reductions in the Gini coefficient of income of 3 percentage points in South Africa (following a cash grants system) and 1 percentage point in Brazil (thanks to social pensions and a conditional cash transfer program called Bolsa Familia).

However, the changes in disposable income due to social transfers also affect households' behaviour and economic performance at different levels (Cherrier et al. 2013). First, additional and/or secure income encourages households to invest in education. International evidence is highly conclusive about a positive effect of social transfers on school attendance. This effect is similar for both conditional and unconditional cash transfers; however, conditional cash transfers have a higher effect in the case of 'marginal children' who were less likely to go to school (Akresh, De Walque, \& Kazianga 2013). Social transfers increase the disposable income and, by reducing costs barriers, increase school enrolment and attendance. But the size of the transfer has to be high enough to cover opportunity costs (e.g., income generated if the child is working) and other school-related costs such as school supplies, transportation, and clothing. The effect on educational achievements was less clear, because it depended on coverage and quality of the educational system (Ponce and Bedi 2010).

The second behavioural income effect of social protection is the investment in health. Several studies provided evidence of the positive effects of different social transfers on food consumption and health status of the population. However, the main determinants of a positive effect were the size 
and periodicity of the transfer, the target group, and complementary investments (Arnold et al. 2011).

Third, changes in disposable income due to social transfers may affect labour supply, because they generate the opportunity to take up work (e.g., covering transportation costs and reducing financial constraints) or to change jobs as the person may be afforded a longer search period. Regarding the argument that higher and secure income may reduce labor supply, it is likely that in the case of poor households the cost of leisure is still too high.

Additional effects are related to households' investments in child wellbeing and productive activities that raise human and physical capital and foster labor productivity. Moreover, social transfers are likely to be spent locally, thereby generating local and regional economic multiplier effects. Enhancing local demand may create incentives for third party investments in the region (i.e., spillover effects). The potential benefits of social transfers can also be affected by conditions outside the strict realm of economics. Although a positive effect on social cohesion and peace building is expected as a result of lower inequality, both social and political will are necessary to sustain social protection investments. Local characteristics (e.g., cultural/religious norms and values) may affect the behaviour of both beneficiaries and nonbeneficiaries. The effects at the individual level will depend on how decisions are taken in the household, which point to the importance of intra-household distribution. Potential behavioural effects that are induced by, for example, conditional social transfers have to be taken into account.

Finally, the cost of social protection has to be quantified to identify its net benefit. Financial affordability of social protection has been one of the main concerns during recent years. Although basic social protection costs compared to GDP appeared to be affordable even for low income countries, 
it demanded an important share of public expenditure (see Arnold et al. 2011; Help Age International 2011). Official development aid (ODA) may be necessary at the beginning in low-income countries, but it is evident that social protection eventually has to be financed from national resources to be sustainable. However, the affordability of social protection, in the end, remains an issue of political choice about the best way to allocate resources (Andrews et al. 2012). In this paper, we concentrated on the economic returns of social transfers through accumulation of human capital. An increase in human capital raises labor productivity, which leads to higher income from work, and this creates a virtuous circle of economic development together with social development and poverty alleviation.

We develop an ex-ante microsimulation model at the household level using data from Cambodia, and we estimate changes in total household consumption due to returns on education. Diverse quantitative techniques were integrated to analyze economic returns of social transfers. A set of social protection instruments (SPI) was chosen based on previous analyses of costeffectiveness. Second, we used a probabilistic regression to estimate the effect of social transfers on school attendance. Third, returns on human capital were calculated at the household level. Finally, a dynamic microsimulation was used to estimate accumulation of human capital and total household consumption over time. The rate of return (RoR) was defined as the ratio of the net present value of benefits (changes in household consumption) to the net present value of costs.

The rest of the paper is organized as follows. Section two exposes the model and how it differs from the existing literature, and it introduces relevant policy information. Estimations based on micro data that will be used to compute the effect of SPI are presented in section three. The effects of SPI 
during a 20-year period in terms of consumption, accumulation of human capital, poverty, inequality, and the rate of return on SPI are reported in section four. Section five offers our conclusions.

\subsection{The model}

Social protection programs are widely acknowledged as an effective strategy for poverty reduction, but their implementation remains challenging in developing countries where resources are scarce and labour informality is high. Different arguments have been advanced to justify non-contributory social protection. Proponents of human rights claim for a basic package of social security for all. Others use growing empirical evidence that show that social transfers alleviate poverty and promote human development. However, additional evidence is needed regarding the economic effects of social transfers to justify public investments.

Various methodologies have been used for cost-benefit analyses of social transfers, and most of them have relied on static models and costing studies (see Cherrier et al. 2013, for a survey). In their survey on the growth impact of social protection, Alderman and Yemtsov (2012) wrote that although positive effects of social transfers on income growth or asset accumulation are well-documented, the final effect at the macro level was not clear, and that the literature estimating rates of return that can be compared to alternative interventions was scarce.

Returns on social protection have to be analyzed from a medium- or longterm perspective. Debowicz and Golan (2014) estimated the effects of cash transfers in Mexico by linking a microsimulation model with a computable general equilibrium model. Using a child's same-gender parent as counterfactual, they found positive effects of lagged acquisition of human 
capital on future income. Similarly, McKee and Todd (2011) estimated longterm income effects using a non-parametric model. They used as counterfactual current adults (25 - 40 years old) and simulated changes in schooling and height based on previous impact evaluations. Their findings showed that investments in human capital increased future mean income, but with a modest effect on earnings inequality. Although these studies approximated long-term effects, they did not follow individuals over time.

Another approach to estimate economic returns of social transfers is to rely on local computable general equilibrium models. In this respect, the Local Economy-wide Impact Evaluation (LEWIE) methodology was implemented in African countries. These studies found real income multipliers of 1.5 in Ghana (Thome et al. 2014), 1.2 in Kenya (Thome et al. 2013; Taylor et al. 2013), 1.4 in Lesotho (Taylor et al. 2014), and 1.26-1.84 in Ethiopia (Kagin et al. 2014). Similarly, an income multiplier of 1.5 -2.6 was found in Mexico (Sadoulet et al. 2001), although Levy and Robinson (2014) found that cash transfers complemented with investments in agriculture productivity increased real GDP by $2.6 \%$ in Cambodia, and Villa (2014) found a 0.15 higher growth rate for treated municipalities in Colombia using luminosity data. However, none of these studies analysed micro-level effects through accumulation of human capital.

From a general methodological perspective, Barrientos and Scott (2008) discussed approaches to study the linkages between social transfers and economic growth. Research at the macro level based on cross-country studies is constrained by the limited availability and quality of data for developing countries, but computable general equilibrium models are strong for analyzing the consistency of social transfers with macro identities, but weak for the analysis of behavioural responses and distributional effects. The 
authors argued that ex-ante simulations of program effects had a higher potential for analyzing social transfers. The methodology was suitable for evaluating policy reforms with behavioural responses (Bourguignon and Ferreira 2003).

In this paper, we focused on economic returns at the micro-level. We followed the idea that the economic effects of social transfers occurred mainly at this level, because they accounted for a small percentage of GDP and they were targeted at poor households (Barrientos 2012). Therefore, we used household level data i to capture distributional effects, which are normally lost by using general equilibrium and other macro models that are based on 'representative agents'. Furthermore, policy costs can be set as endogenous. We relied on microsimulation, because this technique allowed ex-ante simulation of policy effects, which included specific behavioural responses at the individual and household level (Bourguignon and Spadaro 2006). Concerning the latter, we simulated changes in school attendance using probabilistic regression. For the estimation of medium- and long-term economic returns, we designed a dynamic model that included a demographic module for ageing and changes in household composition over time.

A dynamic microsimulation model simulates the behaviour of individuals over time. This kind of model is recommended when no panel data are available or when it comes to estimating the future effect of policies by simulating changes based on micro-level data. It extends static models by allowing individuals to change their characteristics endogenously ( $\mathrm{Li}$ and O'Donoghue 2013). Our model can be extended to include additional behavioural responses and link them with a macro model, but our data are 
limited in this respect. ${ }^{56}$ However, general equilibrium effects may not be relevant at this stage, because Cambodia has a context of low national income with high economic growth, and because social transfers are financed externally. Moreover, a high level of informality reduces the robustness of macro models, and assuming a fixed economic structure over time does not correspond to Cambodia's current situation. Acknowledging that a model is always a simplified view of real life, we present a first attempt to estimate economic rates of returns of social transfers in the long-term using a dynamic microsimulation model for a low-income country.

The social protection instruments (SPI) were considered to be exogenous, but targeting and then costing depended on the households' composition and poverty condition.

The dynamic model included three modules: demography, human capital, and household consumption (Fig. 5.1). Demographic trends were simulated that aligned official projections and estimates of birth rates in households according to household characteristics. Human capital was endogenous. We estimated the effects of SPI on schooling and the effect of schooling on income. In the absence of any reference material, the marginal propensity to consume out of social transfers was assumed to be equal to one. This was reasonable, because SPI was targeted at poor households where savings were usually low. SPI had a direct effect on household consumption and an indirect effect through accumulation of human capital. This was likely to happen in Cambodia, because a GDP growth rate of approximately $7 \%$ was expected, and different policies were being implemented to reach this objective (Royal Goverment of Cambodia 2008). Transfers were allocated to

\footnotetext{
${ }^{56}$ Examples of recent studies that link microsimulation and macro models for the study of the social transfers can be seen in Cury et al. (2010), Khondker et al. (2013), and Debowicz and Golan (2014).

134
} 
beneficiary households based on targeting criteria (i.e., age of individuals, poverty condition, and region). Households were differentiated by the number of members, age, gender, region, household consumption, and poverty condition using the Cambodia Socio-economic Survey (CSES) of 2009. On the basis of the estimates of the model, we simulated the need for SPI, the level of schooling, household consumption, poverty, and inequality for a horizon of 20 periods. 
Figure 5.1. Social protection and socio-economic development.

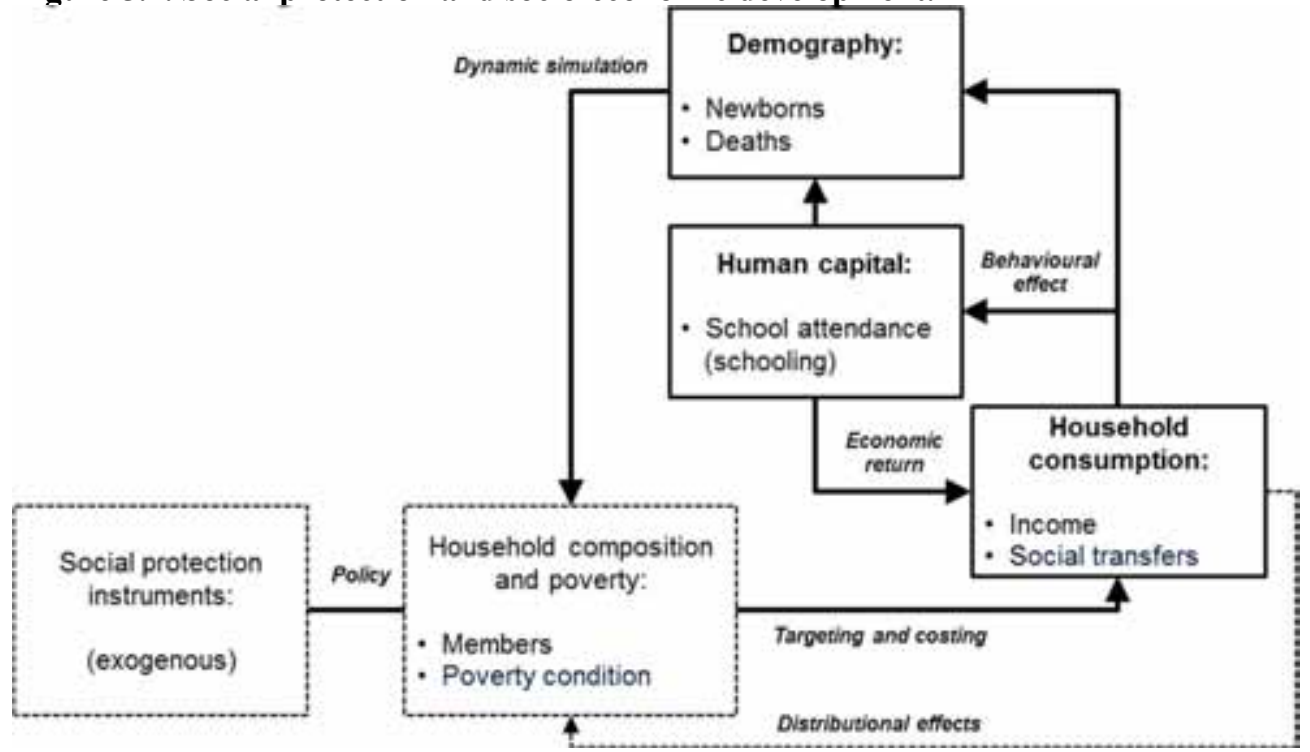

Source: Own calculation.

We defined the rate of return (RoR) on social protection as the ratio in present value terms of the total benefits to total costs that were associated with social protection:

$\operatorname{RoR}_{C, T}=\left[\frac{\sum_{t=1}^{T}\left(C_{t}^{1}-C_{t}^{0}\right)(1+\delta)^{-t}}{\sum_{t=1}^{T} I_{t}(1+\delta)^{-t}}-1\right] \times 100$

Total benefits were measured in terms of total household consumption using the estimated parameters that were based on micro data that we reported in section four, and the total simulated costs of SPI were those of the joint scenario (Table 2). The numerator in equation (1) is the present value of the difference in total household consumption under the policy scenario $\left(C_{t}^{1}\right)$ and the baseline scenario (without SPI) $\left(C_{t}^{0}\right)$ from period 1 to period T. The denominator is the present value of the cost of SPI $\left(I_{t}\right)$ between period 1 and 
period T. Total cost was endogenous in the model and it was calculated at each period taking into account the policy design and the changes in beneficiary household characteristics. $\delta$ was the discount rate used in the calculations of present value. Three values were used $(\delta=\{2 \%, 3 \%, 4 \%\})$. The RoR was calculated for any period between $T=1$ and $T=20$, and represented the net benefit (in terms of household consumption) as the percentage of the SPI's cost in period T.

\subsubsection{Data}

In 2011, the Government of Cambodia launched the National Social Protection Strategy for the Poor and Vulnerable (NSPS). Social protection was seen as a mechanism to protect people against different kinds of risk, and to bring the poor out of poverty. Given the focus on vulnerable people and the level of informality in Cambodia, the first stage for the implementation of the NSPS concentrated on non-contributory instruments, which were assumed to be financed mainly by external sources.

In this paper, a package of social protection instruments (SPI) was defined to simulate the implementation of the NSPS. It included cash transfers, social pensions, scholarships, and public works tha were based on current design proposals and costing studies of the NSPS (Hennicot 2012) (Table 5.1). ${ }^{57}$ Cash transfers were targeted at poor children up to six years old. The transfer was set at $60 \%$ of the rural food poverty line payable on a monthly basis. Second, a social pension was provided to poor individuals 65 years and older with a monthly transfer set at $100 \%$ of the rural food poverty

\footnotetext{
${ }^{57}$ The set of social protection instruments was defined on the basis of their effectiveness to reduce poverty and inequality. The cost-effectiveness analysis is available in Mideros, Gassmann, and Mohnen (2013).
} 
line, thereby guaranteeing a minimum living standard for the poor elderly population. Third, scholarships were defined for poor children in rural areas (including Phnom Penh) for secondary education. Scholarships were set at 50 USD per year (equivalent to $20 \%$ of the rural food poverty line per year), based on information provided by the Ministry of Education Youth and Sport.

Transfers were understood as net amounts. The administrative costs of cash transfers, social pensions, and scholarships were assumed to be $10 \%$ of the transfer value. In the absence of relevant information, perfect targeting was assumed. Although targeting errors should be taken into account for policy design, that was beyond the scope of this study. However, we discuss the potential effect on our estimates in section 5.3.5. Finally, a public work program (PWP) was simulated for poor households in rural areas (including Phnom Penh). The wage was set at 2. 3 USD per working-day for a maximum of 80 days per person per year. It was assumed that only one person per household was included, and that approximately $10 \%$ of eligible households participated. Participation was assigned randomly. Non-wage costs were set at $50 \%$ of total cost, following Hennicot (2012). The model did not include the effects of infrastructure creation and livelihood generation as part of PWP, because this was beyond the scope of the current modeling framework. Therefore, only income effects at the household level were taken into account. The combination of the four social protection instruments (joint scenario) provided social protection over the individual life-cycle, covering early childhood and old age vulnerability, working-age seasonal unemployment, and promotion of school attendance.

We used the data from the 2004 and 2009 waves of the Cambodia Socioeconomic Survey (CSES), which was collected by the National Institute of Statistics (NIS) of the Ministry of Planning (MoP). CSES 2004 (2009) 
included 59,832 $(57,105)$ individuals in 11,988 $(11,971)$ households, which represented a population of 13.0 (14.0) million people. Estimates were based on the pooled data from the two waves so that the estimates represented average effects. ${ }^{58}$ Consumption was estimated for households, because data were only available at this level. It was not possible to analyse intrahousehold distribution. School attendance and labour participation, however, were estimated at the individual level. Wages were available at the individual level only for those working in the formal sector.

In this section, we present the estimated responsiveness of school attendance to changes in income generated by the allocation of social transfers (the behavioural effect) and of consumption due to changes in the length of schooling as a proxy for human capital (the economic return). ${ }^{59}$ These parameters were used in the micro simulations reported in the next section to compute the rates of return of social protection instruments. Finally, we present the results of the demographic projections that underlie the dynamics of the model.

\footnotetext{
${ }^{58}$ We preferred estimating on pooled data to increase the number of observations.

59 Additional estimates on nutrition and labour participation are available in Mideros, Gassmann, and Mohnen (2013).
} 


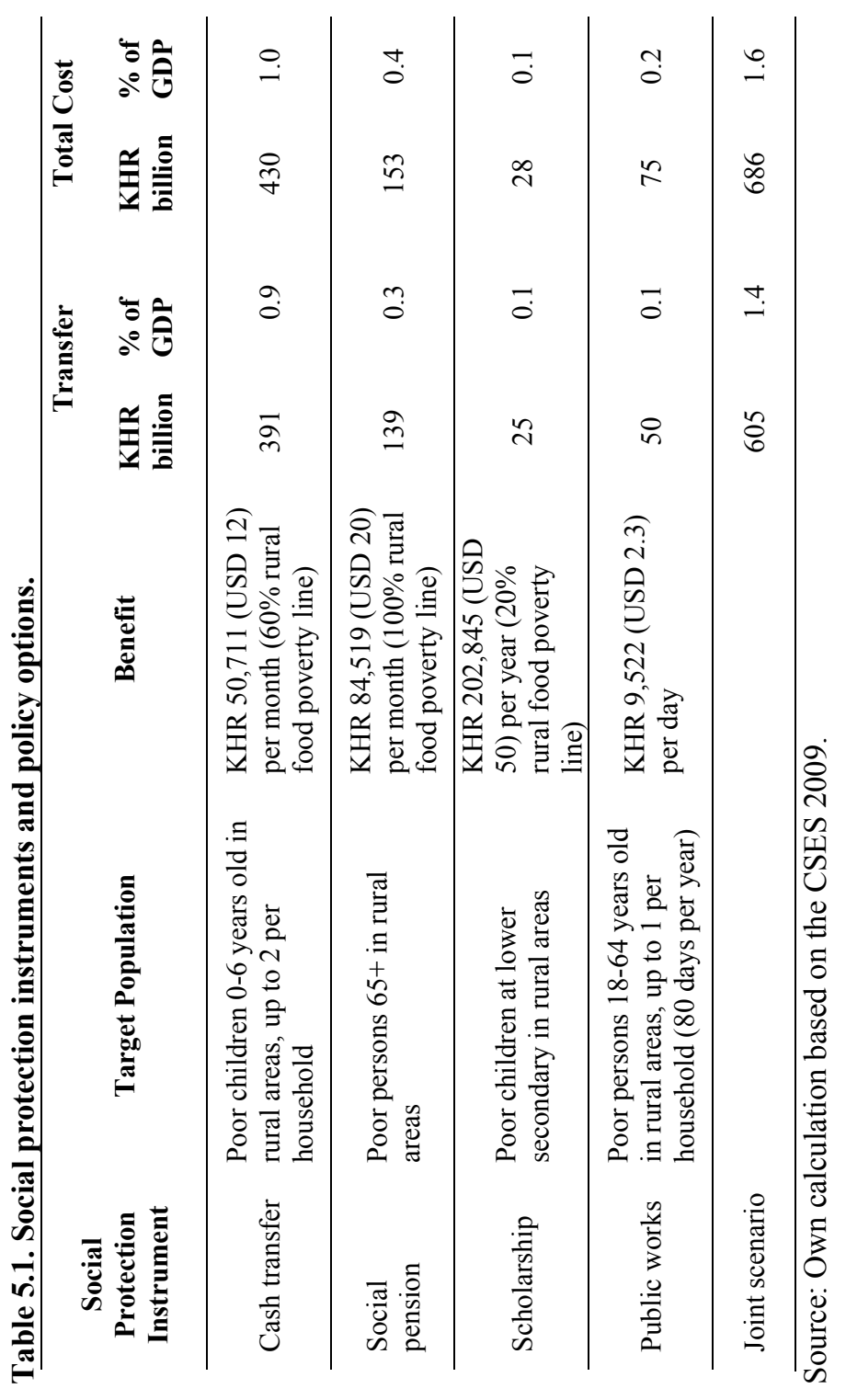




\subsubsection{Behavioural effects: school attendance}

Behavioural effects were limited in this study to the response of changes in disposable income on school attendance. Individual and household characteristics, and regional and time dummies, were used as control variables. ${ }^{60}$ Because income data in the CSES were limited to those working in the formal sector, we used household consumption as a proxy for disposable income.

School attendance was identified in the CSES for all individuals aged five and older. This dichotomous variable took a value of one if a child attended school, and it took a value of zero otherwise. School attendance was not related linearly to age. Attendance was high when a child reached school age up to a point where the opportunity cost compensated the potential benefit of increasing human capital, after which the probability of going to school decreased. ${ }^{61}$ Household economic conditions affected school attendance, because they determined the capacity to cover education costs and the constraints in household resource allocation. ${ }^{62}$ School attendance also depended on previous school achievements. In the case of lower secondary (grades seven to 9) and upper secondary education (grades 10 to 12), the probability that a student continued with the next grade increased. ${ }^{63}$ This observation was consistent with the idea that the benefits of education were

\footnotetext{
${ }^{60}$ For additional information regarding the data underlying our estimations, see Mideros, Gassmann, and Mohnen (2013).

${ }^{61}$ School attendance decreased from $99 \%$ at age six to $94 \%$ at age $12,71 \%$ at age 15 , and $47 \%$ at age 17 . Girls had lower attendance rates than boys at any age (my calculations based on CSES 2009).

${ }^{62}$ School attendance at age 17 was $71.4 \%$ for children in the richest quintile, and $34.1 \%$ for those in the poorest quintile (my calculations based on CSES 2009).

63 The grade was defined as the total number of previous years of schooling plus one for eligible persons between six and 18 years old. For instance, a person who completed four years of education should attend grade 5. Primary education corresponded to grades 1 to 6 , lower secondary education to grades 7 to 9 , and upper secondary education to grades 10 to 12.
} 
related to the achievement of certain levels of education, rather than displaying a continuous return. However, school attendance rates decreased at higher grades of primary education. ${ }^{64}$

School attendance was estimated using an IV probit model, where household consumption, which was considered as endogenous, was instrumented by the exogenous variables of the model in addition to the availability of toilet facility, electricity, and roof quality. In this sense, we approximated behavioural responses by a probabilistic equation. The regression included all individuals 6-25 years old. The total number of observations was 43,562 after pooling the CSES 2004 and 2009 data.

Household consumption was related positively to school attendance (Table 5.2). At the national level a $10 \%$ increase in the level of household consumption per capita led to a $0.2 \%$ higher probability of attending school. This effect was substantially higher for poor households, especially in rural areas. A 10\% increase in household consumption per capita (i.e., 3.4 USD per month for a median poor rural household) was related to a $2.0 \%$ higher probability of attending school in the case of poor households, and a $2.7 \%$ higher probability in poor rural household. If we estimated school attendance for poor rural individuals separately by level of education, we obtained a marginal effect of a $10 \%$ increase in the level of household consumption is related to a $5.6 \%$ higher probability of attending lower secondary education, a $2.2 \%$ higher probability of attending primary education, and a non-precisely (insignificantly) estimated $3.7 \%$ higher probability of attending upper secondary education.

\footnotetext{
${ }^{64}$ School attendance decreases from $99 \%$ to $76 \%$ between grades one and seven. It increases to $81 \%$ at grade nine and to $96 \%$ at grade 12 (own calculations based on CSES 2009). 
Table 5.2. Average marginal effects on the probability of attending school.

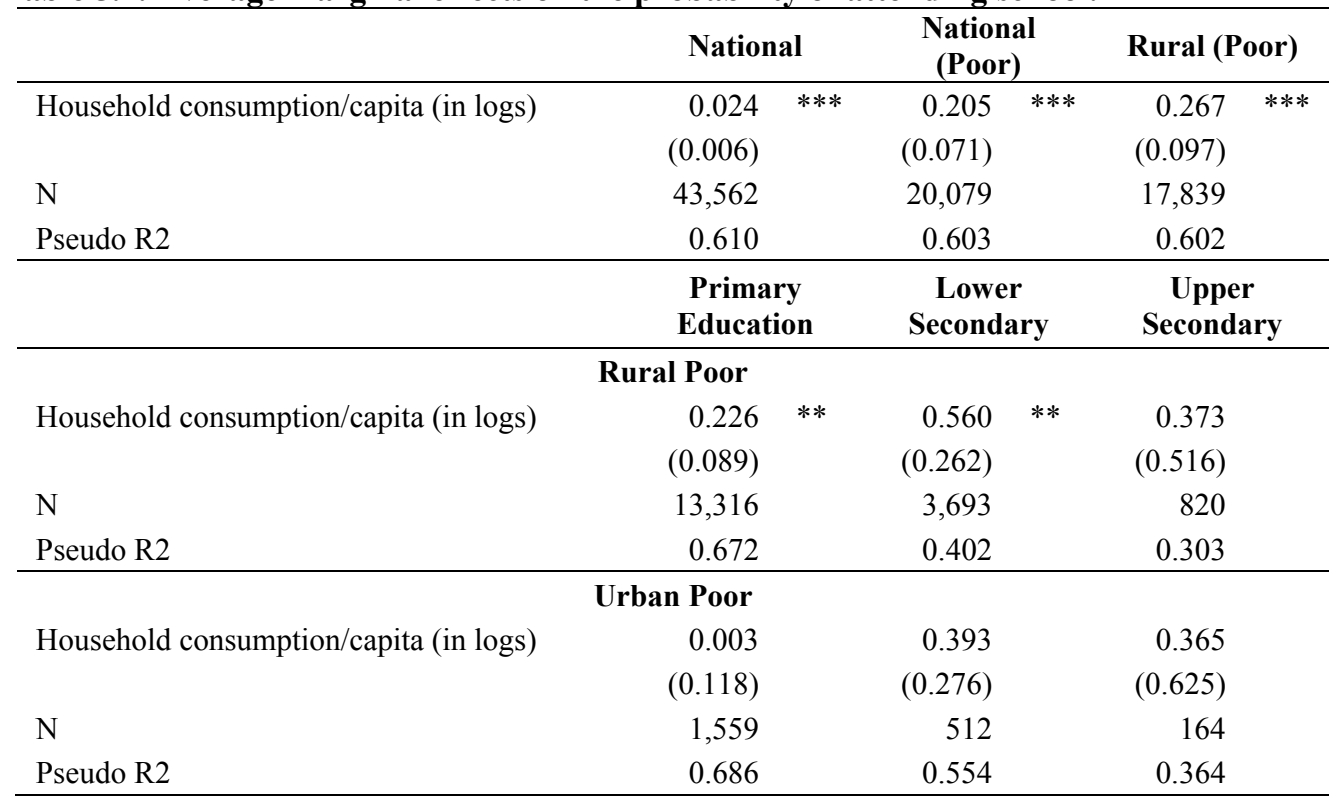

Note: Heteroskedasticity consistent standard errors (between brackets) were estimated using bootstrapping, clustering at the household level, and the delta method. All specifications included as explanatory variables (even if not reported) several control variables at the individual and households levels. For detailed information regarding our estimates, see Mideros, Gassmann and Mohnen (2013).

$* * *$ Significance at $1 \%$, ** significance at $5 \%, *$ significance at $10 \%$

Source: Own calculation based on the CSES 2004 and 2009

Results showed that social transfers, by increasing household disposable income, were likely to affect educational investments and, subsequently, to generate positive effects on accumulation of human capital. In the case of poor rural households, the marginal effect of social transfers on school attendance was higher for lower secondary education. It was not significant for upper secondary education, maybe because of low expected returns in the future. For poor urban households we were unable to get any significant effect of social transfers on schooling, perhaps because of low expected returns or because of the small number of observations. Arguably, complementary policies to increase the quality of education and to enhance future labor opportunities were necessary to create incentives for school attendance, to 
promote human development, and to increase the returns of social protection investments.

\subsubsection{Economic returns for schooling}

Because of the high level of informal work in Cambodia, the estimate of returns for schooling at the individual level could only be performed for a limited fraction of the population. As an alternative, we estimated the returns for schooling at the household level by taking household consumption as a proxy for disposable income. We considered the 'allocative effect' of human capital (i.e., the ability to allocate resources) to be captured by the maximum level of education in the household (Jolliffe 2002).

The maximum level of education was endogenous, and two-stage least squares (2SLS) was used to correct for a possible endogeneity bias (Table $5)^{65}$. The first stage estimated the household's maximum level of education as a function of the education level of the household's head. ${ }^{65}$ The return of an additional year of education on household consumption was 1.6\% (urban) - $1.8 \%$ (rural) for poor households and $2.6 \%$ (rural) - $4.2 \%$ (urban) for nonpoor households. The effect on poor households was similar in urban and rural areas, but for non-poor households the return was lower in rural areas. These results were likely to reflect the participation in economic sectors with lower levels of productivity in the case of poor and rural households (e.g., lower returns were related to agriculture and informal activities).

\footnotetext{
${ }^{65}$ In 2009, the education level of the household head was lower than the maximum education level of the household in $61 \%$ of the cases at the national level. That is, another member of the household had a higher level of education than the household head (my calculations based on CSES 2009). 
Table 5.3. 2SLS estimation of logarithm of household consumption per capita, by region, and poverty condition.

\begin{tabular}{lcrrrrr}
\hline & $\begin{array}{c}\text { Urban } \\
\text { (Non-poor) }\end{array}$ & $\begin{array}{c}\text { Urban } \\
\text { (Poor) }\end{array}$ & $\begin{array}{c}\text { Rural } \\
\text { (Non-poor) }\end{array}$ & $\begin{array}{c}\text { Rural } \\
\text { (Poor) }\end{array}$ \\
\hline $\begin{array}{l}\text { Schooling } \\
(\max )\end{array}$ & $0.042 \quad * * *$ & 0.016 & $* *$ & $0.026 \quad * * *$ & 0.018 & $* * *$ \\
& $(0.005)$ & $(0.007)$ & $(0.003)$ & $(0.002)$ & \\
N & 3,626 & 869 & 9,363 & 7,331 & \\
Adjusted R2 & 0.582 & 0.552 & 0.484 & 0.571 \\
\hline
\end{tabular}

Note: Heteroskedasticity-consistent standard errors, clustered at the primary sample unit, are reported in brackets. All specifications included as explanatory variables (even if not reported) several control variables at the individual and households levels. For detailed information regarding our estimates, see Mideros, Gassmann and Mohnen (2013).

$* * *$ Significance at $1 \%, * *$ significance at $5 \%, *$ significance at $10 \%$

Source: Own calculation based on CSES 2004 and 2009.

\subsubsection{Demography}

Population ageing was based on survival rates that were calculated from official population projections by age, sex, and region (urban and rural), which were available from the National Institute of Statistics (NIS). Age was increased by one year each period. New births were assigned probabilistically to each household, and they differentiated between gender (boys and girls). The probabilities were estimated using a probit model based on household characteristics, and it was restricted to be positive only for households with at least one woman of childbearing age (i.e., 15 - 44 years old). ${ }^{66}$ Subsequently, the estimated total population was compared with official projections (by age, gender, and region), and weights were adjusted by poststratification, by differentiating between urban and rural regions, to be aligned with official projections (see National Institute of Statistics 2011b). Periods corresponded to years using the CSES 2009 as a starting point.

The total population in Cambodia was projected to grow at an average rate of $1.3 \%$ per period, and it increased from 14 million people in period 1

${ }^{66}$ For detailed information regarding our estimates, see Mideros, Gassmann, and Mohnen (2013). 
to 18 million in period 20 (Table 5.4). The relation between rural and total population decreased from 0.8 to 0.7 over the 20 periods, but the total dependency ratio (number of people under 15 years old plus individuals aged 65 and older over number of people 15 - 64 years old) decreased from 0.58 to 0.56 .

Table 5.4. Population projection by period, region, gender, and age (thousands).

\begin{tabular}{lrrrrr}
\hline & Period 1 & Period 5 & Period 10 & Period 15 & \multicolumn{1}{c}{ Period 20 } \\
\hline Population & $\mathbf{1 4 , 0 8 5}$ & $\mathbf{1 4 , 9 4 2}$ & $\mathbf{1 6 , 0 3 4}$ & $\mathbf{1 7 , 0 8 4}$ & $\mathbf{1 8 , 0 0 3}$ \\
Urban & 2,815 & 3,268 & 3,905 & 4,545 & 5,148 \\
Rural & 11,270 & 11,673 & 12,129 & 12,539 & 12,856 \\
\hline Households & $\mathbf{2 , 9 4 5}$ & $\mathbf{3 , 0 7 7}$ & $\mathbf{3 , 1 8 8}$ & $\mathbf{3 , 3 0 1}$ & $\mathbf{3 , 3 7 0}$ \\
Urban & 574 & 640 & 690 & 738 & 778 \\
Rural & 2,371 & 2,437 & 2,498 & 2,563 & 2,592 \\
\hline
\end{tabular}

Source: Own calculation.

\subsection{Rate of return on non-contributory social protection}

In this section, we report by how much the SPI scenario changed the growth rate of household consumption, the level of human capital (years of education) of persons of working-age, how much it affected poverty and inequality, and what the rate of return was on SPI.

\subsubsection{Household consumption}

Household consumption was determined initially using the CSES 2009, and then it was adjusted based on the policy scenario. From the second period onwards, changes in household consumption were simulated through the return on accumulation of human capital (previously calculated). Annual growth rates in total household consumption $\left(g_{C}=\left(C_{t=T} / C_{t=1}\right)^{1 / T}-1\right)$, where $\mathrm{C}$ was household consumption, $\mathrm{T}=1, \ldots, 20)$, were calculated for the base line 
and the SPI policy scenario. The difference between the two outcomes represents the benefit in economic performance at the micro level $\left(B_{C}\right)$ :

$$
B_{C, t=T}=\left[\left(\frac{C_{t=T}^{1}}{C_{t=1}}\right)^{1 / T}-1\right]-\left[\left(\frac{C_{t=T}^{0}}{C_{t=1}}\right)^{1 / T}-1\right]=\frac{\left(C_{t=T}^{1}\right)^{1 / T}-\left(C_{t=T}^{0}\right)^{1 / T}}{\left(C_{t=1}\right)^{1 / T}}(\text { Equation 2) }
$$

Total household consumption grew by an additional $0.04 \%$ if SPI was implemented over the 20-year period. The change in the level of total household consumption in period 1 was due solely to the social transfers, but the increase in subsequent periods was also due to higher human capital (approximated by the years of schooling). Household consumption grew faster if SPI was implemented, which indicated the potential positive economic impact of SPI in Cambodia. The difference decreased over time as the need for social protection went down due to the expected decline in poverty.

\subsubsection{Accumulation of human capital}

Accumulation of human capital was limited to education. School attendance was simulated using the estimated parameters. Benefits (Bs) were defined as the difference between the change in average years of schooling between period 1 and period $\mathrm{T}(\mathrm{T}=1, \ldots 20)$ for the population 18 - 64 years old (i.e., working age) in the policy $\left(s^{1,1}\right)$ and the base line $\left(S^{1,0}\right)$ scenario following:

$$
B_{S^{l}, t=T}=\left(S_{t=T}^{l, 1}-S_{t=1}^{l}\right)-\left(S_{t=T}^{l, 0}-S_{t=1}^{l}\right)=\left(S_{t=T}^{l, 1}-S_{t=T}^{l, 0}\right)
$$

The total average education level was slightly higher if social protection investments were introduced. For example, in periods 5 and 20, the average 
years of schooling was 0.02 and 0.21 years higher $(0.3 \%$ and $1.9 \%$, respectively) under a simulation with SPI than without it. After 10 periods, the positive difference exceeded $1 \%$. Hence, the duration of social protection investments influenced the achievement of benefits in terms of accumulation of human capital.

\subsubsection{Poverty and inequality}

The dynamic effects on poverty $(P)$ and inequality $(G)$ were estimated based on the changes in household consumption. The benefit $\left(B_{P}^{d}, B_{G}^{d}\right)$ was the difference in the changes in poverty and inequality between the base line and policy scenarios over time (from $t=1$ to $t=T, \mathrm{~T}=1, \ldots, 20$ ).

$$
\begin{aligned}
& B_{P, t=T}^{d}=\left(P_{t=1}^{0}-P_{t=T}^{1}\right)-\left(P_{t=1}^{0}-P_{t=T}^{0}\right)=\left(P_{t=T}^{0}-P_{t=T}^{1}\right) \\
& B_{G, t=T}^{d}=\left(G_{t=1}^{0}-G_{t=T}^{1}\right)-\left(G_{t=1}^{0}-G_{t=T}^{0}\right)=\left(G_{t=T}^{0}-G_{t=T}^{1}\right)
\end{aligned}
$$

Poverty and inequality decreased faster in response to SPI. The poverty headcount was 4.8 (2.6)\% lower if SPI were implemented after 5 (20) periods; the Gini coefficient for consumption was $0.014(0.010) \%$ lower with SPI in the same period. The size of these benefits decreased over time; less people received the transfers each period, because it was targeted at the poor. It is important to note that the model did not generate predictions about future poverty levels, because poverty lines changed over time. Social protection investments generated both social and economic benefits in Cambodia.

\subsubsection{Rate of return}

Finally, the RoR became positive after more than 10 years when the net benefit (i.e., difference in total household consumption between policy and 
baseline scenario) exceeded the cost of the investment (including administrative costs). After 15 periods, the social protection investment generated a positive economic return of approximately $5 \%$ and $12 \%-15 \%$ after 20 periods. The RoR increased over time from $-11.6 \%$ in period 1 to $10.1 \%$ in period 5 , and to $11.9 \%-14.7 \%$ in period 20 . This return was related to the benefit of a 0.04 percentage point higher average annual growth rate of household consumption. Although the RoR was defined as the excess of net benefits over net costs at present value for a given discount rate, we alternatively defined the internal rate of return (IRR) as the discount rate that equated to the present value of net benefits and the present value of net costs related to a given social protection scenario. Estimates showed that the IRR was $16 \%$ in period 20 . 
Table 5.5. Benefits, cost, and rate of return (RoR) of social protection in Cambodia.

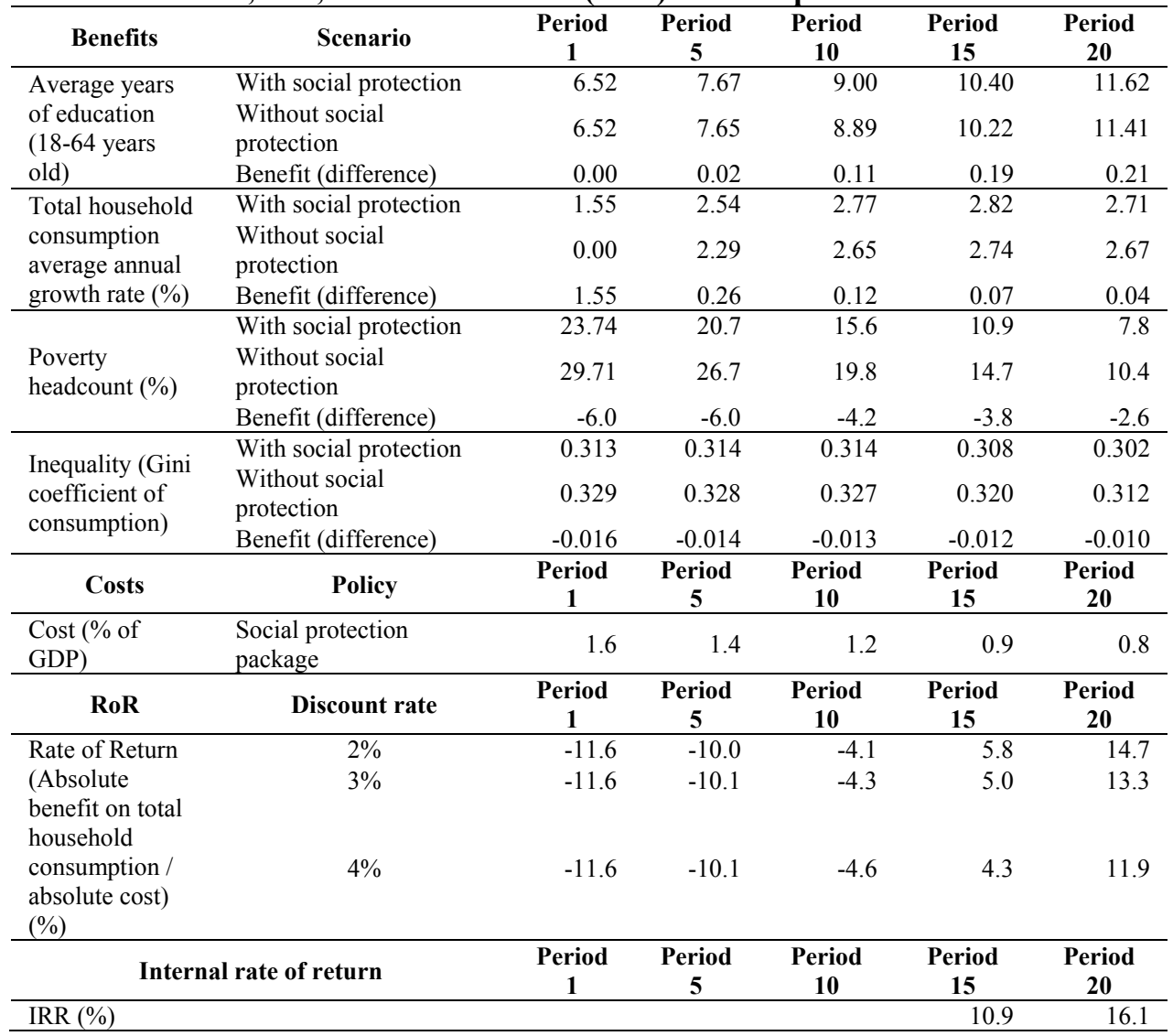

Source: Own calculation using a dynamic microsimulation model.

\subsubsection{Further considerations}

It is important to note that the rate of return that we have calculated was very likely to be underestimated due to the exclusion of institutional changes, strengthening of social cohesion, health improvements (e.g. nutrition), interindustry spillovers, local multiplier effects, and labor supply responses. ${ }^{67}$ Moreover, the model did not include the new infrastructure and improved

67 We found positive effects of increasing household consumption on paid-labour participation for poor persons $18-45$ years old in rural areas, and non-significant effects on poor adults (18 -64 years old) in other areas and age groups (Mideros, Gassmann, and Mohnen, 2013). 
livelihoods that improved productivity, or spillover effects due to higher human capital and consumption. Similarly, complementary policies in the areas of economic productivity, sanitation, health care, and quality of education would only strengthen the positive effect and raise the RoR.

On the other hand, the specific design of social protection interventions, their implementation, administrative issues, and financing aspects also affect the potential benefits and returns of social protection investments. For example, administrative inefficiency, and inclusion and exclusion errors, may reduce the benefits and increase the cost of SPI. In addition, financial sustainability and the effect of taxation and budget reallocation need to be included in a more comprehensive analysis.

Finally, although we assumed that changes in macro-economic and structural conditions cancelled out, because they affected both the situation with and without SPI, they did have relevant effects that should be considered. As we mentioned before, the RoR was estimated on aggregate demand, and it assumed growing productivity capacity, which was a reasonable assumption for Cambodia. But if that was not the case, a more comprehensive analysis of general equilibrium effects would be needed. Furthermore, higher (lower) general productivity may raise (lower) the return on education and, subsequently, increase (decrease) the benefits and returns. Moreover, increasing household disposable income due to economic growth may reduce the cost of the SPI, because poverty would be reduced, but it would also reduce the positive effect on behavioural responses.

\subsection{Final remarks}

This study used an ex-ante dynamic microsimulation model to estimate the economic rate of return on non-contributory social transfers in the medium 
and long term in Cambodia. The data were from the Cambodian Socioeconomic Survey (CSES), and the selected policy option was in line with the National Social Protection Strategy (NSPS).

Our estimates, which were based on micro data, revealed that social protection transfers increased school attendance, that increased education augmented household consumption per capita, and that poverty and inequality decreased faster with social protection. However, the benefit was not generated immediately. This supports the idea that investments in social protection require a long-term commitment, and social transfers should be regular and reliable to achieve positive effects through the increase in a households' permanent income. The average annual growth rate in household consumption was 0.04 percentage points higher 20 years after the implementation of the SPI policy. It means that social protection investments have the potential to increase economic growth, as long as the economy can react to higher effective demand, which is likely to happen if resources are not being fully utilized and/or if income is expected to grow, as in the case of Cambodia and other low-income countries.

Finally, the rate of return on social protection (RoR) was calculated by dividing the difference in household consumption under the scenario with SPI and the baseline scenario without it by the cost of the policy, all discounted properly. The cost of the proposed policy reached 1.6\% of GDP in period 1, and then it decreased s to $0.8 \%$ of GDP in period 20 . This amount of resources seems affordable for a low-income country like Cambodia, and the political will was established in the NSPS. RoR was $11.9 \%-14.7 \%$ in period 20 , using different rates of discount, which means that the investment was more than recovered fully, including administrative costs. 
It is important to note that due to data limitations, all SPI were simulated as cash transfers, and the returns were assumed to be the same for all SPI. Behavioural (income) effects may differ depending on the specific design characteristics of the SPI. In addition, the model did not include financing issues. In this sense, the final results may be overestimated. On the other hand, behavioural (non-income) effects, such as health improvements (e.g., nutrition), spillovers, regional multipliers, and institutional effects, were not taken into account, which most probably resulted in an underestimate of the returns. Moreover, if SPI was implemented as part of a multi-sector strategy, returns like sanitation conditions, quality and coverage of infrastructure and public services (e.g., health and education) could be developed, and economic productivity would be increased. Even more, social protection by solving human capital constraints helps to generate the conditions for future economic development.

This study shows that dynamic micro simulation models can complement traditional cost-effectiveness and cost-benefit analyses by providing mid- and long-term economic returns on social protection policies.

\subsection{References}

Akresh, R., D. De Walque, and H. Kazianga. 2013. Cash Transfers and Child

Schooling: Evidence from a Randomized Evaluation of the Role of Conditionality. Policy Research Working Paper 6340. Washington: World Bank. doi: 10.1596/1813-9450-6340.

Alderman, H., and R. Yemtsov. 2012. Productive Role of Safety Nets. Social Protection and Labor Discussin Paper 1203. Washington: The World Bank. http://www.worldbank.org/. 
Andrews, C., M. Das, J. Elder, M. Ovadiya, and G. Zampaglione. 2012.

Social Protection in Low Income Countries and Fragile Situations.

Social Protection and Labour Discussion Paper 1209. Washington:

World Bank. http://www.worldbank.org/.

Arnold, C., T. Conway, and M. Greenslade. 2011. Cash Transfers. Evidence

Paper. London: Department for International Development.

Barrientos, A. 2005. Non-contributory pensions and poverty reduction in

Brazil and South Africa. Manchester: IDPM, University of Manchester. http://www.sed.manchester.ac.uk/.

Barrientos, A. 2012. Social Transfers and Growth: What Do We Know? What

Do We Need to Find Out? World Development 40 (1): 11-20. doi: 10.1016/j.worlddev.2011.05.012.

Barrientos, A., and J. Scott. 2008. Social Transfers and Growth: A Review. BWPI Working Paper 52. Manchester: Brooks World Poverty Institute. http://www.bwpi.manchester.ac.uk/.

Bourguignon, F., and F. Ferreira. 2003. Ex Ante Evaluation of Policy Reforms Using Behavioural Models. In The Impact of Economic Policies on Poverty and Income Distribution: Evaluation Techniques and Tools, edited by L. Pereira da Silva, and F. Bourguignon, 123-141. New York: World Bank and Oxford University Press.

Bourguignon, F., and A. Spadaro. 2006. Microsimulation as a tool for evaluating redistribution policies. Journal of Economic Inequality 4 (1): 77-106. doi: 10.1007/s10888-005-9012-6.

Bourguignon, F., F. H. Ferreira, and P. G. Leite. 2003. Conditional cash transfers, schooling, and child labour: Micro-simulating Brazil's Bolsa Escola program. The World Bank Economic Review 17 (2): 229-254. doi: 10.1093/wber/lhg018. 
CamNut. 2012. Nutrition Library, CamNut, Accessed February 3. http://sites.google.com/site/camnutlibrary/data.

Cherrier, C., F. Gassmann, A. Mideros, and P. Mohnen. 2013. Making the investment case for social protection. Methodological challenges with lessons learnt from a recent study in Cambodia. Working Paper 201306. Florence: UNICEF Office of Research. http://www.unicef-irc.org/.

Cury, S., E. Pedrozo, A. Mori Coelho, and I. Callegari. 2010. The Impacts of Income Transfer programs on Income Distribution and Poverty in Brazil: An Integrated Microsimulation and Computable General Equilibrium Analysis. MPIA Working Paper 2010-20. Nairobi: Partnership for Economic Policy - Modeling and Policy Impact Analysis. http://portal.pep-net.org/.

Debowicz, D., and J. Golan. 2014. The impact of Oportunidades on human capital and income distribution in Mexico: A top-down/bottom-up approach. Journal of Policy Modelling 36 (1): 24-42. doi: 10.1016/j.jpolmod.2013.10.014.

Help Age International. 2011. Financing Social Pensions in Low and Middle Income Countries. London: Help Age International Briefing.

Hennicot, J. C. 2012. Financial Assessment of the National Social Protection Strategy for the Poor and Vulnerable Draft v.2. Phnom Penh: International Labour Organization.

Jolliffe, D. 2002. Whose Education Matter in the Determination of Household Income? Evidence from a Developing Country. Economic Development and Cultural Change 50 (2): 287-312.

Kagin, J., E. Taylor, D. Alfani, and B. Davis. 2014. Local Economy-wide Impact Evaluation (LEWIE) of Ethiopia's social cash transfer pilot 
programme. Rome: Food and Agriculture Programme (FAO). http://www.fao.org/.

Khondker, B. H., C. Knox-Vydmanov, and A. Vilela. 2013. Old Age Social Protection Options for Bangladesh. Dhaka: Bureau of Economic Research Dhaka University and Help Age International.

Levy, S., and S. Robinson. 2014. Can cash transfers promote the local economy? Discussion Paper 01334. Washington D.C.: IFPRI. http://www.ifpri.org/.

Li, J., and C. O'Donoghue. 2013. A survey of dynamic microsimulation models: uses, model structure and methodology. International Journal of Microsimulation, 6 (2): 3-55. http://www.microsimulation.org/.

McKee, D., and P. Todd. 2011. The long-term effects of human capital enrichment programs on poverty and inequality: Oportunidades in Mexico. Estudios de Economía 38 (1): 67-100. http://www.estudiosdeeconomia.cl/.

Mideros, A., F. Gassmann, and P. Mohnen. 2013. Estimation of rates of return on social protection: Making the case for non-contributory social transfers in Cambodia. Working Paper 2013-063. Maastricht: UNUMERIT and Maastricht Graduate School of Governance. http://www.merit.unu.edu/.

National Institute of Statistics. 2009. General Population Census of Cambodia 2008. Phnom Penh: Royal Government of Cambodia, Ministry of Planning.

National Institute of Statistics. 2010a. Cambodia Socio-Economic Survey 2009. Phnom Penh: Royal Government of Cambodia, Ministry of Planning. 
National Institute of Statistics. 2010b. Labour and Social Trends in Cambodia. Phnom Penh: Royal Government of Cambodia, Ministry of Planning.

National Institute of Statistics. 2011a. National Accounts of Cambodia 19932000. Phnom Penh: Royal Government of Cambodia, Ministry of Planning.

National Institue of Statistics. 2011b. Report 12. Population Projections of Cambodia. Phnom Penh: Royal Government of Cambodia, Ministry of Planning.

Notten, G., and F. Gassmann. 2008. Size Matters: Targeting Efficiency and Poverty Reduction Effects of Means-tested and Universal Child Benefits in Russia. Journal of European Social Policy, 18 (3): 260-274. doi: $10.1177 / 0958928708091059$.

Ponce, J., and A. Bedi. 2010. The Impact of a Cash Transfer Programme on Cognitive Achievements: The Bono de Desarrollo Humano of Ecuador. Economis of Education Review 29 (1): 116-125.

Royal Goverment of Cambodia. 2008. Rectangular Strategy fo Growth, Employment, Equity and Efficiency. Phase II. Phnom Penh: Royal Goverment of Cambodia.

Royal Government of Cambodia. 2009. National Strategic Development Plan. Update 2009-2013. Phnom Penh: Royal Government of Cambodia. Sadoulet, E., A. De Janvry, and B. Davis. 2001. Cash transfer program with income multipliers: Procampo in Mexico. World Development 29 (6): 1043-1056. doi: 10.1016/S0305-750X(01)00018-3.

Schady, N., and M. C. Araujo. 2006. Cash Transfers, Conditions, School Enrolment and Child Work: Evidence from a Randomized Experiment in 
Ecuador. Policy Research Working Paper 3930. Washington: World Bank. http://www.worldbank.org/.

Schady, N., and J. Rosero. 2008. Are Cash Transfers Made to Women Spent like Other Sources of Income? Economic Letters 101 (3): 246-248. doi: 10.1016/j.econlet.2008.08.015.

Taylor, E., J. Kagin, M. Filipski, and K. Thome. 2013. Evaluating general equilibrium impacts of Kenya's cash transfer programme for orphans and vulnerable children (CT-OVC). Rome: Food and Agriculture Organization (FAO). http://www.fao.org/.

Taylor, E., K. Thome, and M. Filipski. 2014. Evaluating local general equilibrium impacts of Lesotho's child grants programme. Rome: Food and Agriculture Organization (FAO). http://www.fao.org/.

Thome, K., M. Filipski, J. Kagin, J. E. Taylor, and B. Davis. 2013. Agricultural spillover effects of cash transfers: What does LEWIE have to say? Amer. J. Agr. Econ. 95 (5): 1338-1344. doi: 10.1093/ajae/aat039.

Thome, K., E. Taylor, J. Kagin, B. Davis, R. Barko Osei, and I. Osei-Akoto. 2014. Local Economy-wide Impact Evaluation (LEWIE) of Ghana's Livelihood Empowerement Against Poverty (LEAP) Programme. Rome: Food and Agriculture Organization (FAO). http://www.fao.org/.

UNDP. 2011. Human Development Report 2011. Sustainability and Equity: A Better Future for All. New York: United Nations Development Programme.

UNICEF. 2012. Integrated Social Protection Systems. Enhancing Equity for Children. New York: United Nations Children's Fund.

Villa, J. M. 2014. Social transfers and growth. The missing evidence crom luminosity data. Working Paper 2014/09. Helsinki: UNU-WIDER. http://www.wider.unu.edu/. 


\section{Chapter 6 - Concluding remarks}

This thesis addressed a number of issues with respect to the economic effects of non-contributory social protection. Although it is primarily an academic work, its societal relevance is related to global policy recommendations to end poverty, promote inclusive economic growth, and reduce inequality, which are all part of the sustainable development goals (SDG). This book is a scientific commitment to contribute to social justice, and it is an attempt to connect social and economic policies. The feasibility of poverty eradication and inequality reduction does not depend on economic growth alone, but also on redistribution. Moreover, the implementation of social protection floors in developing countries must not be seen only from a human rights and social development perspective, but also as an investment and a powerful solution to poverty traps and to promote social mobility and economic capacity.

Relevant concerns regarding social transfers include labour (dis)incentives, accumulation of human capital, social mobility, and the estimation of rates of return. To address these issues, this thesis acknowledged that poor people have specific context conditions. In the case of labour supply, it is not possible to think of people enjoying leisure without being able to cover their basic needs. Investing in human capital is not only a matter of rational choice, but also of the capability to cover opportunity and transaction costs. Social mobility is not just the result of personal effort, but it is conditioned to poverty traps. In addition, giving money to the poor can be more than charity, because it is a commitment to strong economic policy to enhance aggregate demand and to foster local economies.

Each chapter contributes in three different ways. First, new empirical evidence was presented for Ecuador and Cambodia. Second, new theoretical 
insights were generated regarding labour supply, accumulation of human capital, and social mobility. Third, we proved that microsimulation models are a powerful tool for ex-ante evaluation and analysis of cost-effectiveness.

In this sense, we shed new light on the economic effects of noncontributory social protection and under what conditions social transfers promote a sustainable path out of poverty, while fostering economic performance. The main findings of the thesis showed that non-contributory social protection investments fostered economic performance. With respect to the four sub-questions, the main conclusions can be summarized as follows:

\section{Under what conditions do non-contributory social transfers promote} labour participation? - Although traditional labour supply theories argue that a social transfer discourages labour, we concluded that it was not the case for poor individuals who can barely cover their basic needs, because leisure in this context may not be enjoyable. Estimating a unitary discrete labour supply model using data from Ecuador, we found non-negative effects of social transfers on household heads' labour supply, but only below a given level of social transfers. On the other hand, negative labour supply effects were found for partners (who were mainly women) and single adults, where a social transfer may have paid for childcare, but also because of idiosyncratic characteristics and labour market obstacles found by women. We believe that policies that address gender equity and childcare should complement social transfers if paid-labour participation of partners is a final objective. However, it should be assessed carefully how such policies would affect child wellbeing and the freedom to choose any kind of work.

How and to what extent do non-contributory social transfers affect accumulation of human capital? - Using a dynamic cohort microsimulation 
model for Ecuador, we found that social transfers promoted higher levels of schooling. However, social transfers were more cost-efficient to promote accumulation of human capital if they were targeted at critical ages, and they were more efficient in reducing schooling inequality if targeted at the poorest of the poor. Social transfers have the potential to promote accumulation of human capital and, in the long term, economic returns. However, the effect depends on the guarantee of coverage and the quality of educational services.

Under what conditions do non-contributory social transfers foster social mobility? - Using long-term administrative panel data, we found a positive treatment effect for social transfers. That is, non-contributory social protection generated positive welfare effects. Additionally, we found that the amount of the transfer was important, which may have been due to relaxation of demographic and physical capital poverty traps. Moreover, social transfers aimed not only at guaranteeing a minimum level of consumption, but also at promoting productive investments, had a higher effect on multivariate social mobility. To enable social mobility, anti-poverty policies should be oriented towards improving access to physical capital, income generating activities (i.e., labour), and the accumulation of human capital to promote reproductive health, foster gender equity, and reduce welfare and opportunity gaps between ethnic groups and between urban and rural areas. To solve poverty traps, social protection instruments should consider household composition and economic vulnerabilities, and they should be complemented with policies that strengthen the determinants of upward social mobility. Moreover, social transfers should not only be assessed by their impact on household consumption smoothing, but also as an instrument that can foster social mobility, due to their potential to solve different poverty traps. 


\section{What is the economic rate of return of non-contributory social}

protection investments? - We also found a positive rate of return of social protection investments in Cambodia. Estimates revealed that social transfers increased school attendance, and that increased education augmented household consumption. However, the benefit was not generated immediately. This supported the idea that investments in social protection require a long-term commitment, and that social transfers should be regular and reliable to achieve positive effects through an increase in the permanent income of households. Moreover, economic returns due to higher aggregate demand (i.e., consumption) depended on the economy being able to react, which was likely to happen if resources were not fully utilized.

All these results indicated that social protection programmes must be seen as an investment rather than as a cost. However, the effects were contextspecific. The economic effects of social transfers depended on labour market conditions, access to financial services and productive assets, coverage and quality of health and educational services, social exclusion, and general economic performance. The cases of Ecuador and Cambodia were complementary, and they represented different contexts. Ecuador is a middle income country with large experience with social transfers, and it has been increasing coverage and quality of social services during recent years. Cambodia is a low-income country with small social protection programmes and limited social services. We found that social transfers had a greater effect on school attendance in Cambodia, where opportunities and transportation costs may be higher due to low coverage of educational services and lower life conditions, while the effect on labour supply and social mobility was greater in Ecuador due to higher complementarities between socio and economic policies. 
Further research should address the analysis of policy complementarities. For example, what is the joint effect of social transfers and economic inclusion policies, as technical assistance, fair trade, technological diffusion, and access to financial services and productive assets? Moreover, the study of intergenerational social mobility needs new data that follows the life path of beneficiary children, which are not available at this moment. Qualitative and quantitative analysis of social exclusion and gender and ethnic inequalities is required to better understand the non-monetary determinants of poverty. Finally, research on economic multipliers at the meso- and macrolevel is needed to reach conclusions on aggregate economic effects. 


\section{Valorization}

Relevance - The relevance of the present dissertation entitled "Essays on the economic effects of non-contributory social protection" is related to global policy recommendations to end poverty, promote inclusive economic growth, and reduce inequality, which are all part of the sustainable development goals (SDG). This book is a scientific contribution to social justice, and it is an attempt to connect social and economic policies. The feasibility of poverty eradication and inequality reduction depends not only on economic growth, but also on redistribution. Moreover, the implementation of social protection floors in developing countries must not be seen only from a human rights and social development perspective, but also as an investment and a powerful solution to poverty traps and to promote social mobility and economic capacity.

This thesis acknowledges that poor people have specific context conditions. In the case of labour supply, it is not possible to think of people fully enjoying leisure without being able to cover their basic needs. Investing in human capital is not only a matter of rational choice, but it is conditioned on the capability to cover opportunity and transaction costs. Social mobility is not just the result of personal effort, but it is conditioned to poverty traps. In addition, giving money to the poor is more than charity, because it is a commitment to strong economic policy to enhance aggregate demand and to foster local economies.

Target groups - Apart from the academic community, this book has informational value and policy recommendations for national governments, 
non-governmental organizations, and other international organizations that are committed to the sustainable development goals.

Activities and products - All the contributions have been presented at academic conferences, and they are being published in academic journals. In addition, the models are detailed presented and Op-Ed articles have been published looking for a broad impact on public debates. Even more, results have been presented to government representatives of Cambodia and Ecuador.

Innovation - The innovation value of this research is due to new empirical evidence regarding poverty and poverty reduction in Ecuador and Cambodia. In addition, new theoretical insights were generated regarding labour supply, accumulation of human capital, and social mobility. Finally, microsimulation models were proven to be a powerful tool for ex-ante evaluation and analysis of cost-effectiveness.

Schedule and implementation - I foresee a plan for the next few years that is based on the efforts made in this dissertation to generate policy recommendations and complementary theoretical and empirical research projects. Moreover, results were presented to government official both in Cambodia and Ecuador. In the case of Ecuador results are being used to design policy reforms to the $\mathrm{BDH}$ and social pension in order to increase coverage and to complement social transfers with additional social and economic programmes. 


\section{Summary}

Global GNI per-capita (PPP, current international \$) accounted to 16,100 USD in 2016. However, $10.7 \%$ of the population was still living in poverty, on less than 1.90 USD a day. The first of the sustainable development goals (SDG) that were approved in 2015 by the United Nations' General Assembly aims to "end poverty in all its forms everywhere", mandating to "implement nationally appropriate social protection systems and measures for all".

Social protection is a human right and, therefore, it is an obligation of states to guarantee it to their citizens. Non-contributory social protection has been proven to be affordable at least for a minimum level of benefits, and international research is highly conclusive with regard to its positive effects on human development dimensions like health and education. However, there are still questions regarding its economic effects in the medium and long terms.

The research question of this thesis is Under what conditions do noncontributory social protection investments foster economic performance? To answer it, four sub-questions were explored: Under what conditions do non-contributory social transfers promote labour market participation? How and to what extent do non-contributory social transfers affect accumulation of human capital? Under what conditions do non-contributory social transfers foster social mobility? And finally, what is the economic rate of return of noncontributory social protection investments?

This thesis generates new light on the economic effects of noncontributory social protection and under what conditions social transfers promote a sustainable path out of poverty, while fostering economic 
performance. The main findings of the thesis show that non-contributory

\section{social protection investments do foster economic performance.}

Although traditional labour supply theories argue that a social transfer discourages labour, we discuss that it is not the case for poor individuals who y can barely cover their basic needs, because leisure in this context may not be enjoyable. We find non-negative effects of social transfers on household heads' labour supply in Ecuador, but only below a given level of social transfers. On the other hand, negative labour supply effects were found for partners (who were mainly women) and single adults, where a social transfer may have paid for childcare, but also because of idiosyncratic characteristics and labour market obstacles found by women. We believe that policies that address gender equity and childcare should complement social transfers if paid-labour participation of partners is a final objective. However, it should be assessed carefully how such policies would affect child wellbeing and the freedom to choose any kind of work.

Estimating a dynamic cohort microsimulation model for Ecuador, we found that social transfers promoted higher levels of schooling. However, social transfers were more cost-efficient to promote accumulation of human capital if they were targeted at critical ages, and more efficient in reducing schooling inequality if targeted at the poorest of the poor. Social transfers have the potential to promote accumulation of human capital and, in the long term, economic returns. However, the effect depends on the guarantee of coverage and quality of educational services.

Using long-term administrative panel data, we found a positive treatment effect for social transfers. Non-contributory social protection generated positive welfare effects. Additionally, we found that the amount of the transfer was important, which may be related to the possibility of relaxing 
demographic and physical capital poverty traps. Moreover, social transfers aimed not only at guaranteeing a minimum level of consumption, but also at promoting productive investments, had a higher effect on multivariate social mobility. To enable social mobility, anti-poverty policies should be geared towards improving access to physical capital and income generating activities (i.e., labour) and the accumulation of human capital to promote reproductive health, foster gender equity, and reduce welfare and opportunity gaps between ethnic groups and between urban and rural areas. To solve poverty traps, social protection instruments should consider household composition and economic vulnerabilities, and they should be complemented with policies that strengthen the determinants of upward social mobility. Moreover, social transfers should not only be assessed by their impact on smoothing of household consumption, but also as an instrument that can foster social mobility, due to their potential to solve different poverty traps.

Finally, we found a positive rate of return of social protection investments in Cambodia. Estimates revealed that social transfers increased school attendance, and that increased education augmented household consumption. However, the benefit was not generated immediately. Investments in social protection require a long-term commitment and social transfers should be regular and reliable to achieve positive effects through the increase in the permanent income of household. Moreover, economic returns due to higher aggregate demand (i.e., consumption) depend on the economy being able to react, which is likely to happen if resources are not fully utilized.

All these results show that social protection programmes must be seen as an investment rather than as a cost. However, the effects are context-specific. The economic effects of social transfers depend on labour market conditions, access to financial services and productive assets, coverage and quality of 
health and education services, social exclusion, and general economic performance. 


\section{Biography}

Andrés was born in 1981 in Quito, Ecuador. He is an economist from the Catholic University of Ecuador (1995). He holds a Master Degree in Economics, major in Development Economics, from the Latin American Faculty of Social Science, FLACSO - Ecuador, where he received the Best Thesis Award (2010). He is also Master of Science in Public Policy and Human Development from Maastricht University, where he received the Top 3\% and Best Thesis Awards (2011). Andrés started his $\mathrm{PhD}$ research at Maastricht Graduate School of Governance, Maastricht University and UNUMERIT, in 2011.

Currently, he is Minister of Development and Planning in Ecuador, and Assistant Professor on Development Economics at the Catholic University of Ecuador. He writes on poverty and inequality, social protection and socioeconomic development, with occasional excursions into governance and politics. He has more than fifteen years of experience as researcher and consultant. Besides, he has served in international organizations and governmental institutions in Ecuador as Ministerial Advisor on social policy, Technical Secretary for the Eradication of Poverty, and Vice minister of Social Development. 


\section{UNU-MERIT/MGSoG Dissertation Series}

2017

Tobias Brioch

New Actors in the Global Economy

UNU-MERIT/MGSoG Dissertation

Series № 194

Bernard Nikaj

From No-government to E-government

UNU-MERIT/MGSoG Dissertation

Series № 193

Ali Safarnejad

Prioritizing the HIV Response

UNU-MERIT/MGSoG Dissertation

Series № 192

Clovis Freire

Diversification and Structural

Economic Dynamics

UNU-MERIT/MGSoG Dissertation

Series № 191

Michael Verba

Innovation and Knowledge Dynamics:

Essays on the Knowledge Economy

UNU-MERIT/MGSoG Dissertation

Series № 190

Pui Hang Wong

The Hearts and Minds in Conflict and

Peace:The Economics of

Counterinsurgency and the Psychology of Reconstruction

UNU-MERIT/MGSoG Dissertation

Series № 189
Brenda Yamba

Schooling Despite All Odds: Evidence

from Lesotho on Female Child Carers

who Stayed in School

UNU-MERIT/MGSoG Dissertation

Series № 188

Sheng Zhong

Moving towards An Energy Efficient

Future; Essays on Energy Efficiency,

Technology and Development

UNU-MERIT/MGSoG Dissertation

Series № 187

Julieta Marotta

Access to Justice and Legal

Empowerment of Victims of Domestic

Violence through Legal Organizations

in the City of Buenos Aires; A

Qualitative Empirical Legal Study

UNU-MERIT/MGSoG Dissertation

Series, № 186

Andrea Franco-Correa

On the Measurement of

Multidimensional Poverty as a Policy

Tool; Empirical Applications to Chile,

Colombia, Ecuador and Peru

UNU-MERIT/MGSoG Dissertation

Series, № 185 
Yesuf Awel

Insurance for Growth; Empirical

Essays on Insurance Demand and

Impacts in Africa

UNU-MERIT Dissertation Series,

№ 108

Tigist Mekonnen Melesse

Grow More Food using Fewer

Resources;

Agricultural Technology Adoption and

Innovation Practices for Inclusive and

Sustainable Development

UNU-MERIT Dissertation Series,

№ 107

Eleni Yitbarek

Getting Ahead or left Behind?; Essays on Poverty Dynamics and Social

Mobility in Africa

UNU-MERIT Dissertation Series, № 106

Thuy Dieu Nguyen

Firm-Level Theory and Evidence of

Corruption

UNU-MERIT Dissertation Series, № 105

Raquel Tsukada Lehman

Essays on Household Production with

Labor-Saving Technology

UNU-MERIT Dissertation Series, № 104
Eva Barteková

Multi-Problem Challenges for a

Renewable Future; Empirical Studies

on Competitive Disadvantages from

Electricity Price Differentials and

Mineral Supply Risk in an Open

Economy

UNU-MERIT Dissertation Series,

№ 103

Jocelyn Olivari

Entrepreneurial Traits and Innovation;

Evidence from Chile

UNU-MERIT Dissertation Series,

№ 102

Muhammad Shafique

Essays on the role of knowledge, RED,

and Technology-based Firms in the

Evolution of Socio-techno-economic

System

UNU-MERIT Dissertation Series, № 101

Serdar Türkeli

Governance of Innovation Policy;

Empirical Studies on Applied Political

Economy by Multi-Methods Analysis

UNU-MERIT Dissertation Series,

№ 100

Ayokunu Adedokun

Pathways to Sustainable Peacebuilding in Divided Societies; Lessons and Experiences from Mozambique

MGSoG Dissertation Series, № 75 
Luiz Rothier Bautzer

Organizing Concurrent Engineering

through ICT Platforms

Blueprinting Product Lifecycle

Management Platforms across

Disciplinary Agencies

MGSoG Dissertation Series, № 74

Natalia Popova

Migration in the Periphery of the

European Union;

Determinants of Successful and

Sustainable Labour Market Integration of Return Migrants in Albania, Egypt, Moldova and Tunisia

MGSoG Dissertations Series, № 73

Richard A. Martina

Uncertainty and Resource Constraint in the Small Island Developing States;

Essays in Entrepreneurial Cognition

MGSoG Dissertations Series, № 72

Cécile Cherrier

The Expansion of Basic Social

Protection in Low-income Countries;

An Analysis of Foreign Aid Actors'

Role in the Emergence of Social

Transfers in Sub-Saharan Africa

MGSoG Dissertations series, № 71
Paul Caldron

The Tacit Bargain in Short-Term

Medical Missions; Why U.S.

physicians go and what it costs

MGSoG Dissertation Series, № 70

\section{Mahmut Kobal}

Customs \& Excellence: A Comparative Approach on Administrative and Regulatory Compliance Perspectives of the EU-Turkey Customs Union

MGSoG Dissertation Series, № 69

Craig Loschmann

Essays on Conflict-related Migration

and Development in the Case of

Afghanistan

MGSoG Dissertations Series, № 68

Andrea Milan

Rural Livelihoods, Location and

Vulnerable Environments; Approaches

to Migration in Mountain areas of

Latin America

MGSoG Dissertation Series, № 67

Farida Lada

On Guarding the Welfare of Clinical

Trial Subjects While Promoting Novel

Drug Innovation

A Game Theoretical Approach

MGSoG Dissertation Series, № 66

\section{5}

Hibret Belete Maemir

Dissecting Aggregate Productivity;

International Integration and Growth

with Heterogeneous Firms

UNU-MERIT Dissertation Series, № 96 
Giorgio Triulzi

Looking for the Right Path; Technology

Dynamics, Inventive Strategies and

Catching-up in the Semiconductor

Industry

UNU-MERIT Dissertation Series, № 95

Abdul Baseer Qazi

Knowledge flows and networks in the

ICT sector; The case of Pakistan

UNU-MERIT Dissertation Series,

№ 94

Ajay Thutupalli

Technology Paradigm Shifts in

Agriculture; Drivers of Sustainability

and Catch up

UNU-MERIT Dissertation Series,

№ 93

Eduardo Urias

Improving access to HIVIAIDS

treatment in Brazil; When are

Compulsory Licenses effective in Price

Negotiations?

UNU-MERIT Dissertation Series, № 92

Francesca Guadagno

Why have so few Countries

Industrialised?

UNU-MERIT Dissertation Series, № 91

Daniel Opolot

The Evolution of Beliefs and Strategic

Behaviour

UNU-MERIT Dissertation Series, № 90
Alejandro Lavopa

Structural Transformation and

Economic Development; Can

Development Traps be Avoided

UNU-MERIT Dissertation Series, № 89

Jinjin Zhao

Urban water management reform; The

Case of China

UNU-MERIT Dissertation Series,

№ 88

Simona Vezzoli

Borders, Independence and Post-

colonial Ties; the Role of the State in

Caribbean Migration

MGSoG Dissertation Series, № 65

Silvia Consuelo Gómez Soler

Civil Conflict and Education; How

Does Exposure to Civil Conflict Affect

Human Capital Accumulation?

Evidence from Standardized Exit

Exams in Colombia

MGSoG Dissertation Series, № 64

Paula Nagler

Occupational Choice in the Developing

World

MGSoG Dissertation Series, № 63

Jasmin Kientzel

Determinants of Professional

Commitment to Environmental

Sustainability

MGSoG Dissertation Series, № 62 
Mehmet Güney Celbiş

Regional Policies; Convergence, Trade, and the Allocation of Public Capital

MGSoG Dissertation Series, № 61

Florian Henning

Living Up to Standard;

Interoperability Governance and

Standards Adoption in Government

Information Networks

MGSoG Dissertation Series, № 60

Niels P. Groen

The Never-Ending Project

Understanding E-Government Project

Escalation

MGSoG Dissertation Series, № 59

\section{Derek Copp}

Teacher-Based Reactivity to Provincial

Large-scale Assessment in Canada

MGSoG Dissertation Series, № 58

Michaella Vanore

Family-Member Migration and the

Psychosocial Health Outcomes of

Children in Moldova and Georgia

MGSoG Dissertation Series, № 57

\section{4}

\section{Dirk Crass}

The Impact of Brands on Innovation and Firm Performance; Empirical

Evidence from Germany

UNU-MERIT Dissertation Series, № 87

\section{Sonja Fransen}

The Economic and Social Effects of Remittances and Return Migration in Conflict-Affected Areas; The Case of Burundi

MGSoG Dissertation Series, № 56

Ibrahim Khalil Conteh

The Impact of Floods on Primary

School Education in Zambia

MGSoG Dissertation Series, № 55

Richard Bluhm

Growth Dynamics and Development

Essays in Applied Econometrics and

Political Economy

MGSoG Dissertation Series, № 54

Nevena P. Zhelyazkova

Work-Family Reconciliation and Use of

Parental Leave in Luxembourg;

Empirical Analysis of Administrative

Records

MGSoG Dissertation Series, № 53
Samyukta Bhupatiraju

The Geographic Dimensions of Growth and Development

UNU-MERIT Dissertation Series, № 86

François Lafond

The Evolution of Knowledge Systems

UNU-MERIT Dissertation Series, № 85 
Annalisa Primi

Promoting Innovation in Latin

America; What Countries Have

Learned (and What They Have Not) in

Designing and Implementing

Innovation and Intellectual Property

Policies

UNU-MERIT Dissertation Series, № 84

Fatoumata Lamarana Diallo

Evaluation of Meal and Deworming

Programs for Primary Schools in Rural

Senegal

UNU-MERIT Dissertation Series, № 83

Sachin Kumar Badkas

Metachoice and Metadata; Innovating with Environmental Policy Analysis in Europe

MGSoG Dissertation Series, № 52

Irina S. Burlacu

An Evaluation of Tax-Benefit Systems Impact on the Welfare of Frontier

Worker;

The Case of Luxembourg and Belgium MGSoG Dissertation Series, № 51

Özge Bilgili

Simultaneity in Transnational

Migration Research; Links Between

Migrants' Host and Home Country

Orientation

MGSoG Dissertation Series, № 50
Yulia Privalova Krieger

Reshaping the Big Agenda;

Transnational Politics and Domestic

Resistance Financial crisis and social

protection reform in Bosnia and

Herzegovina

MGSoG Dissertation Series, № 49

Marieke van Houte

Moving Back or Moving Forward?

Return migration after Conflict

MGSoG Dissertation Series, № 48

Oxana Slobozhan

Global Governance in the Management of Natural Resources; The Case of the Extractive Industries Transparency Initiative (EITI)

MGSoG Dissertation Series, № 47

Luis Bernardo Mejia Guinand

The Changing Role of the Central

Planning Offices in Latin America; A

Comparative Historical Analysis

Perspective (1950-2013)

MGSoG Dissertation Series, № 46

Cheng Boon Ong

Ethnic Segregation in Housing,

Schools and Neighbourhoods in the

Netherlands

MGSoG Dissertation Series, № 45

Luciana V. Cingolani

Bureaucracies for Development;

Oxymoron or Reality? Studies on State

Capacity in Challenging Governance

Contexts

MGSoG Dissertation Series, № 44 
Carlos Cadena Gaitán

Green Politics in Latin American

Cities - Sustainable Transport Agendas

MGSoG Dissertation Series, № 43

Katie Kuschminder

Female Return Migration and

Reintegration Strategies in Ethiopia

MGSoG Dissertation Series, № 42

Metka Hercog

Highly-Skilled Migration and New

Destination Countries

MGSoG Dissertation Series, № 41

\section{3}

Anant Kamath

Information Sharing through Informal

Interaction in Low-Tech Clusters

UNU-MERIT Dissertation Series, № 82

Flavia Pereira de Carvalho

What we talk about when we talk about

Brazilian Multinationals; An

Investigation on Brazilian FDI,

Economic Structure, Innovation and

the Relationship between them

UNU-MERIT Dissertation Series,

№ 81

Jun Hou

Complementarity in Innovation and

Development; A Cross-country

Comparison

UNU-MERIT Dissertation Series, № 80
Margaret Agaba Rugadya

Can Remittances Influence the Tenure

and Quality of Housing in Uganda?

MGSoG Dissertation Series, № 40

Ilire Agimi

New Governance Under Limited

Statehood; The Case of Local

Government Reform in Kosovo

MGSoG Dissertation Series, № 39
Rufin Baghana

Impacts of Government Incentives to $R \mathcal{E} D$, Innovation and Productivity; A Micro econometric Analysis of the Québec Case

UNU-MERIT Dissertation Series, № 79

Lilia I. Stubrin

High-Tech Activities in Emerging Countries; A Network perspective on the Argentinean Biotech Activity UNU-MERIT/MGSoG Dissertation Series, № 78

Kristine Farla

Empirical Studies on Institutions, Policies and Economic Development MGSoG Dissertation Series, № 38 
Marina Petrovic

Social Assistance and Activation in the

Pursuit of Happiness; Shedding New

Light on Old Policy Solutions to Social Exclusion

MGSoG Dissertation Series, № 37

Laura Torvinen

Assessing Governance Assessments;

The Case of Mozambique; Governance

Assessments in the Context of Aid

Effectiveness Discourse

MGSoG Dissertation Series, № 36

Biniam Egu Bedasso

Institutional Change in the Long

Shadow of Elite; Essays on

Institutions, Human Capital and

Ethnicity in Developing Countries

MGSoG Dissertation Series, № 35

\section{2}

Abdul Waheed

Innovation Determinants and

Innovation as a Determinant; Evidence

from Developing Countries

UNU-MERIT Dissertation Series, № 77

Bilal Mirza

Energy Poverty and Rural Energy

Markets in Pakistan

UNU-MERIT Dissertation Series, № 76

Benjamin Engelstätter

Enterprise Software and Video Games;

An Empirical Analysis

UNU-MERIT Dissertation Series,

№ 75
Sepideh Yousefzadeh Faal Deghati Childhoods Embargoed; Constructing and Reconstructing Multidimensional Child Poverty in Iran 1984-2009

MGSoG Dissertation Series, № 34

Robert Bauchmüller

Investing in Early Childhood Care and

Education; The Impact of Quality on

Inequality

MGSoG Dissertation Series, № 33

Martin Rehm

Unified Yet Separated; Empirical

Study on the Impact of Hierarchical

Positions within Communities of

Learning

MGSoG Dissertation Series, № 32
Fulvia Farinelli

Natural Resources, Innovation and

Export Growth; The Wine Industry in

Chili and Argentina

UNU-MERIT Dissertation Series

Rodolfo Lauterbach

Innovation in Manufacturing; From

Product Variety and Labor

Productivity Growth to Economic

Development in Chile

UNU-MERIT Dissertation Series 
Kirsten Wiebe

Quantitative Assessment of

Sustainable Development and Growth

in Sub-Saharan Africa

UNU-MERIT/MGSoG Dissertation

Series, № 74

Julio Miguel Rosa

Organizational Strategies, Firms'

Performance and Spatial Spillovers;

The Canadian Case in Research and

Development.

UNU-MERIT Dissertation Series, № 73

Johannes Wilhelmus Marie Boels Joseph Schumpeter, Honderd Jaar Economische Ontwikkeling; Een Historisch-theoretische Beschouwing. UNU-MERIT Dissertation Series

Dorcas Mbuvi

Utility Reforms and Performance of the Urban Water Sector in Africa MGSoG Dissertation Series, № 31

\section{1}

Daniel Vertesy

Interrupted Innovation; Emerging

Economies in the Structure of the

Global Aerospace Industry

UNU-MERIT Dissertation Series,

№ 72

Tina Saebi

Successfully Managing Alliance

Portfolios; An Alliance Capability

View

UNU-MERIT Dissertation Series, № 71
Lina Salanauskaite

Distributional Impacts of Public

Policies; Essays in Ex-Ante and Ex-

Post Evaluation

MGSoG Dissertation Series, № 30

Esther Schüring

To Condition or not - is that the

Question?

An Analysis of the Effectiveness of ExAnte and Ex-Post Conditionality in Social Cash Transfer Programs

MGSoG Dissertation Series, № 29

Joe Abah

Strong Organisations in Weak States;

Atypical Public Sector Performance in

Dysfunctional Environments

MGSoG Dissertation Series, № 28

Zina Samih Nimeh

Social Citizenship Rights; Inequality and Exclusion

MGSoG Dissertation Series, № 27

Nora Engel

Tuberculosis in India; A Case of

Innovation and Control

UNU-MERIT/MGSoG Dissertation

Series, № 70

Evans Mupela

Connectivity and growth in Sub-

Saharan Africa; The Role of

Communication Satellites

UNU-MERIT Dissertation Series, № 69 
Nantawan Kwanjai

Cross Cultural Intelligence amid

Intricate Cultural Webs; A Tale of the

UnDutchables in the Land of 1002

Smiles

UNU-MERIT Dissertation Series, № 68

Lina Sonne

Innovation in Finance to Finance

Innovation; Supporting Pro-poor

Entrepreneur-based Innovation

UNU-MERIT Dissertation Series,

№ 67

Lenka Eisenhamerová

Legitimacy of 'Humanitarian Military

Intervention'

MGSoG Dissertation Series, № 26

Sonila Tomini

Informal Payments for Health Care

Services in Albania

MGSoG Dissertation Series, № 25

Jinjing Li

Dynamic Microsimulation in Public

Policy Evaluation

MGSoG Dissertation Series, № 24

Aziz Atamanov

Rural Nonfarm Employment and

International Migration as

Alternatives to Agricultural

Employment; The Case of Kyrgyzstan

MGSoG Dissertation Series, № 23

Frieda Vandeninden

Poverty Alleviation; Aid and Social

Pensions

MGSoG Dissertation Series, № 22
Juliana Nyasha Tirivayi

The Welfare Effects of Integrating

AIDS Treatment with Food Transfers;

Evidence from Zambia

MGSoG Dissertation Series, № 21

Agnieska Ewa Sowa

Who's Left Behind? Social Dimensions

of Health Transition and Utilization of

Medical Care in Poland

MGSoG Dissertation Series, № 20

Emmanaouil Sfakianakis

The Role of Private Actors in the

Provision of Public Goods with

Applications to Infrastructure and

Financial Stability

MGSoG Dissertation Series, № 19

Siu Hing Lo

White Collars Green Sleeves; An Inter-

organizational Comparison of

Determinants of Energy-Related

Behaviors among Office Workers

MGSoG Dissertation Series, № 18

Treena $\mathrm{Wu}$

Constraints to Human Capital

Investment in Developing Countries;

Using the Asian Financial Crisis in

Indonesia as a Natural Experiment

MGSoG Dissertation Series, № 17

Henry Espinoza Peña

Impact Evaluation of a Job-Training

Programme for Disadvantaged Youths;

The Case of Projoven

MGSoG Dissertation Series, № 16 
Fernando Santiago

Human Resources Management

Practices and Learning for Innovation

in Developing Countries;

Pharmaceutical Firms in Mexico

UNU-MERIT Dissertation Series,

№ 66

Zakaria Babutsidze

Essays on Economies with

Heterogeneous Interacting Consumers

UNU-MERIT Dissertation Series,

№ 65

Bertha Vallejo

Learning and Innovation Under

Changing Market Conditions; The

Auto Parts Industry in Mexico

UNU-MERIT Dissertation Series,

№ 64

Donatus Ayitey

Technical Change, Competitiveness

and Poverty Reduction; A Study of the

Ghanaian Apparel Industry

UNU-MERIT Dissertation Series,

№ 63

Sergey Filippov

Multinational Subsidiary Evolution;

Corporate Change in New EU Member

States

UNU-MERIT Dissertation Series, № 62
Asel Doranova

Technology Transfer and Learning

under the Kyoto Regime; Exploring the

Technological Impact of CDM Projects

in Developing Countries

UNU-MERIT Dissertation Series, № 61

Florian Tomini

Between Family and Friend;

Understanding the Interdependency of

Private Transfers

MGSoG Dissertation Series, № 15

Michał Polalowski

The Institutional Transformation of

Social Policy in East Central Europe;

Poland and Hungary in Comparative

and Historical Perspective

MGSoG Dissertation Series, № 14

Maha Ahmed

Defining, Measuring and Addressing

Vulnerability; The Case of Post

Conflict Environments

MGSoG Dissertation Series, № 13

Pascal Beckers

Local Space and Economic Success; The

Role of Spatial Segregation of Migrants in the Netherlands

MGSoG Dissertation Series, № 12 
Victor Cebotari

Conflicting Demands in Ethnically

Diverse Societies; Ethno political

Contention and Identity Values in

Europe

MGSoG Dissertation Series, № 11

Dennis Gyllensporre

Competing and Complementary

Perspectives on the EU as a Crisis

Management Actor;

An Examination of the Common

Security and Defence Policy through

the Lenses of Idealism and Realism

MGSoG Dissertation Series, № 10

Judit Vall Castello

Business Cycle and Policy Effects on

Labour Market Transitions of Older

and Disabled Workers in Spain

MGSoG Dissertation Series, № 9

\section{9}

Alexis Habiyaremye

From Primary Commodity Dependence to Diversification and Growth;

Absorptive Capacity and Technological

Catch Up in Botswana and Mauritius.

UNU-MERIT Dissertation Series,

№ 60

Yoseph Getachew

The Role of Public Capital in Economic

Development

UNU-MERIT Dissertation Series,

№ 59
Keetie Roelen

False Positives or Hidden Dimensions;

The Definition and Measurement of

Child Poverty

MGSoG Dissertation Series, № 8

Denisa Maria Sologon

Earning Dynamics in Europe

MGSoG Dissertation Series, № 7

Melissa Siegel

Money and Mobility; Migration and

Remittances

MGSoG Dissertation Series, № 6

Jessica S. Hagen-Zanker

Modest Expectations; Causes and

Effects of Migration on Migrant

Households in Source Countries

MGSoG Dissertation Series, № 5

Sandra Leitner

Embodied Technological Change and

Patterns of Investment in Austrian

Manufacturing

UNU-MERIT Dissertation Series, № 58

Semih Akçomak

The Impact of Social Capital on

Economic and Social Outcomes

UNU-MERIT Dissertation Series, № 57 
Abraham Garcia

The Role of Demand in Technical

Change

UNU-MERIT Dissertation Series, № 56

Saurabh Arora

Coherence in Socio-technical Systems;

A Network Perspective on the

Innovation Process

UNU-MERIT Dissertation Series, № 55
Mirtha R. Muniz Castillo

Human Development and Autonomy in Project Aid; Experiences from four bilateral projects in Nicaragua and $\mathrm{El}$ Salvador

MGSoG Dissertation Series, № 4

Christiane Arndt

Governance Indicators

MGSoG Dissertation Series, № 3

Britta Augsburg

Microfinance; Greater Good or Lesser Evil?

MGSoG Dissertation Series, № 2

2008

Rutger Daems

Medicines for the Developing World UNU-MERIT Dissertation Series, № 54

Johannes Hanel Assessing Induced Technology; Sombart's Understanding of Technical Change in the History of Economics UNU-MERIT Dissertation Series, № 53

Rifka Weehuizen

Mental Capital; the Economic Significance of Mental Health UNU-MERIT Dissertation Series, № 52
Danielle Cloodt

The Relationship between RED

Partnership Formation, Social

Embeddedness and Innovative

Performance

UNU-MERIT Dissertation Series, № 51

Sabine Fuss

Sustainable Energy Development

under Uncertainty

UNU-MERIT Dissertation Series, № 50

Geranda Notten

Measuring and Managing Poverty

Risks

MGSoG Dissertation Series, № 1 
Tobias Kronenberg

Reconciling Environmental

Conservation with Economic

Prosperity; The Feasibility of Double

Dividends in the Short and Long Run

UNU-MERIT Dissertation Series,

№ 49

Viktoria Kravtsova

Assessing the Impact of Foreign Direct

Investment in Transition Economies

UNU-MERIT Dissertation Series,

№ 48

2006

Bulat Sanditov

Essays on Social Learning and

Imitation

UNU-MERIT Dissertation Series, № 46

Mamata Parhi

Dynamics of New Technology

Diffusion; A Study of the Indian

Automotive Industry

UNU-MERIT Dissertation Series, № 45

Andreas Reinstaller

Social Structures and the Innovation

Process; Their Role in the Demand of

Firms and Consumers

UNU-MERIT Dissertation Series, № 44
Suhail Sultan

The Competitive Advantage of Small and Medium Sized Enterprises; The

Case of Jordan's Natural Stone

Industry

UNU-MERIT Dissertation Series, № 47

Rose Kiggundu

Innovation systems and Development;

The Journey of a Beleaguered Nile

Perch Fishery in Uganda

UNU-MERIT Dissertation Series, № 43

Thomas Pogue

The Evolution of Research

Collaboration in South African Gold

Mining; 1886-1933

UNU-MERIT Dissertation Series, № 42

Geoffrey Gachino

Foreign Direct Investment, Spillovers

and Innovation; The Case of Kenyan

Manufacturing Industry

UNU-MERIT Dissertation Series, № 41 
Önder Nomaler

Technological Change, International

Trade and Growth; An Evolutionary,

Multi-Agents-Based Modeling

Approach

UNU-MERIT Dissertation Series,

№ 40

2005

Samia Satti Osman Mohamed-Nour

Change and Skill Development in the Arab Gulf Countries

UNU-MERIT Dissertation Series, № 39

Elad Harison

Intellectual Property Rights;

Economics and Policy Analysis

UNU-MERIT Dissertation Series, № 38

Daniel Dalohoun

The Relationship between RED

Partnership Formation, Social

Embeddedness and Innovative

Performance; a Multi-level Approach of Social Embeddedness

UNU-MERIT Dissertation Series, № 37

Müge Ozman

Networks, Organizations and

Knowledge

UNU-MERIT Dissertation Series, № 36
Bas Straathof

Product Variety and Economic

Growth; The Counteracting Effects of

Scale and Idiosyncrasy

UNU-MERIT Dissertation Series, № 35

Wilfred Schoenmakers

Knowledge Flows between

Multinational Companies; A Patent

Data Analysis

UNU-MERIT Dissertation Series,

№ 34

Myriam Cloodt

Mergers and Acquisitions ( $M$ and As)

in High-Tech Industries; Measuring

the Post-M and A Innovative

Performance of Companies

UNU-MERIT Dissertation Series, № 33 
Paola Criscuolo

$R \mathcal{E D}$ Internationalisation and

Knowledge Transfer; Impact on MNEs and their Home Countries

UNU-MERIT Dissertation Series, № 32

Maarten Verkerk

Trust and Power on the Shop Floor UNU-MERIT Dissertation Series, № 31

Nadine Roijakkers

Inter-firm Cooperation in High-tech Industries; a Study of RED

Partnerships in Pharmaceutical

Biotechnology

UNU-MERIT Dissertation Series, № 28

Viki Sonntag

Speed, Scale and Sustainability

UNU-MERIT Dissertation Series, № 27

2002

Annelies Hogenbirk

Determinants of Inward Foreign

Direct Investment; the Case of the

Netherlands

UNU-MERIT Dissertation Series, № 24
Gottfried Leibbrandt

Adoption, Harmonization and

Succession of Network Technologies

across Countries

UNU-MERIT Dissertation Series, № 30

Mark Sanders

Skill Biased Technical change; Its

Origins, the Interaction with the

Labour Market and Policy Implications

UNU-MERIT Dissertation Series,

№ 29

Masaru Yarime

From End-of-Pipe Technology to Clean

Technology

UNU-MERIT Dissertation Series,

№ 26

Stéphane Malo

The Combinatorial Chemistry

Revolution; Sustaining a Superior

Performance Position through

Technological Learning

UNU-MERIT Dissertation Series,

№ 25

Bastiaan Johan ter Weel

The Computerization of the Labour

Market

UNU-MERIT Dissertation Series 
John Adeoti

Technology Investment in Pollution

Control in Sub-Saharan Africa; The

Case of the Nigerian Manufacturing Industry

UNU-MERIT Dissertation Series, № 23
Edward Huizenga

Innovation Management; How

Frontrunners Stay Ahead; An

Empirical Study on Key Success

Factors in the ICT sector

UNU-MERIT Dissertation Series, № 22

2000

Machiel van Dijk

Technological Change and the Dynamics of Industries; Theoretical Issues and Empirical evidence from Dutch Manufacturing

UNU-MERIT Dissertation Series, № 21

1999

Jan Cobbenhagen

Managing Innovation at the Company

Level; A Study on Non-Sector-Specific

Success Factors

UNU-MERIT Dissertation Series, № 20
Marjolein Caniëls

Regional Growth Differentials; The

Impact of Locally Bounded Knowledge

Spillovers

UNU-MERIT Dissertation Series, № 19

1998

\section{Aldo Geuna}

Resource Allocation and Knowledge production; Studies in the Economics of University Research

UNU-MERIT Dissertation Series, № 18

1996

Reinoud Joosten

Dynamics, Equilibria, and Values

UNU-MERIT Dissertation Series, № 17
Hugo Kruiniger

Investment, RED, and the Financing

Decisions of the Firm

UNU-MERIT Dissertation Series, № 16 
Hans van Meijl

Endogenous Technological Change;

The Case of Information Technology,

Theoretical Considerations and

Empirical Results

UNU-MERIT Dissertation Series, № 15

René Kemp

Environmental Policy and Technical

Change; A Comparison of the

Technological Impact of Policy

Instruments

UNU-MERIT Dissertation Series, № 14
Rohini Acharya

The Impact of New Technologies on

Economic Growth and Trade; A Case

Study of Biotechnology

UNU-MERIT Dissertation Series, № 13

Geert Duysters

The Evolution of Complex

Industrial Systems; The Dynamics of Major IT Sectors

UNU-MERIT Dissertation Series, № 12

Marjan Groen

Technology, Work and Organisation;

A Study of the Nursing Process in

Intensive Care Units

UNU-MERIT Dissertation Series,

№ 11

Hans Voordijk

Naar Integrale Logistiek in

Bedrijfsketens; Ontwikkelingen in de Bouw

UNU-MERIT Dissertation Series, № 8

Theon van Dijk

The Limits of Patent Protection; Essays

on the Economics of Intellectual

Property Rights

UNU-MERIT Dissertation Series,

№ 9 
Paul Diederen

Technological Progress in Enterprises and Diffusion of Innovation;.

Theoretical Reflections and Empirical Evidence

UNU-MERIT Dissertation Series,

№ 7

1992

Bart Verspagen

Uneven Growth Between

Interdependent Economies; An

Evolutionary View on Technology

Gaps, Trade and Growth

UNU-MERIT Dissertation Series,

№ 4

1989

John Spangenberg

Economies of Scale, and Atmosphere in Research Organisations

UNU-MERIT Dissertation Series, № 2

\section{8}

John Hagedoorn

Evolutionary and Heterodox Innovation Analysis; A Study of Industrial and

Technological Development in Process Control and Information Technology

UNU-MERIT Dissertation Series, № 1
Ben Dankbaar

Economic Crisis and Institutional

Change; The Crisis of Fordism from the

Perspective of the Automobile Industry

UNU-MERIT Dissertation Series,

№ 6

Hanno Roberts

Accountability and Responsibility; The

Influence of Organisation Design on

Management Accounting

UNU-MERIT Dissertation Series,

№ 5

Sjoerd Romme

A Self-organization Perspective on

Strategy Formation

UNU-MERIT Dissertation Series,

№ 3 